\title{
Heat shock protein 70 as an indicator of toxic heavy metal exposure and oxidative stress in the serum of asymptomatic shipyard welders
}

\author{
Sung Gu Han \\ West Virginia University
}

Follow this and additional works at: https://researchrepository.wvu.edu/etd

\author{
Recommended Citation \\ Han, Sung $\mathrm{Gu}$, "Heat shock protein 70 as an indicator of toxic heavy metal exposure and oxidative stress \\ in the serum of asymptomatic shipyard welders" (2005). Graduate Theses, Dissertations, and Problem \\ Reports. 4155. \\ https://researchrepository.wvu.edu/etd/4155
}

This Dissertation is protected by copyright and/or related rights. It has been brought to you by the The Research Repository @ WVU with permission from the rights-holder(s). You are free to use this Dissertation in any way that is permitted by the copyright and related rights legislation that applies to your use. For other uses you must obtain permission from the rights-holder(s) directly, unless additional rights are indicated by a Creative Commons license in the record and/ or on the work itself. This Dissertation has been accepted for inclusion in WVU Graduate Theses, Dissertations, and Problem Reports collection by an authorized administrator of The Research Repository @ WVU.

For more information, please contact researchrepository@mail.wvu.edu. 
HEAT SHOCK PROTEIN 70 AS AN INDICATOR OF TOXIC HEAVY METAL

EXPOSURE AND OXIDATIVE STRESS IN THE SERUM OF ASYMPTOMATIC

SHIPYARD WELDERS

Sung Gu Han

Dissertation submitted to the

Davis College of Agriculture, Forestry and Consumer Sciences

at West Virginia University

in partial fulfillment of the requirements

for the degree of

Doctor of Philosophy

in

Genetics and Developmental Biology

Val Vallyathan, Ph.D., Chair Joginder Nath, Ph.D., Co-Chair

Vincent Castranova, Ph.D.

Dan Panaccione, Ph.D.

Sharon Wenger, Ph.D.

Morgantown, West Virginia 2005

Keywords: Heat Shock Protein, Lung Injury, Biomarker, Reactive Oxygen Species, Welding Fume, Metal Toxicity

Copyright 2005 Sung Gu Han 


\author{
ABSTRACT \\ HEAT SHOCK PROTEIN 70 AS AN INDICATOR OF TOXIC HEAVY METAL \\ EXPOSURE AND OXIDATIVE STRESS IN THE SERUM OF ASYMPTOMATIC \\ SHIPYARD WELDERS
}

Sung Gu Han

Heat shock protein 70 (Hsp70) expression has been reported to be a sensitive biomarker of cell stress. Arsenic (As), cadmium (Cd), mercury $(\mathrm{Hg})$, chromium $(\mathrm{Cr})$, nickel (Ni), vanadium (V), and manganese (Mn) are widely used and exposure to these metals is associated with the development of pulmonary disease. Our data showed that exposure to these metals resulted in a significant increase in cytotoxicity, apoptosis, and generation of reactive oxygen species (ROS) in a human bronchial cell line, BEAS-2B. However, increased Hsp70 expression was observed only in cells exposed to As, Cd, and $\mathrm{Hg}$. To correlate changes associated with Hsp70 overexpression, cytotoxicity, lipid peroxidation, and ROS generation were measured. Exposure of BEAS-2B cells to As, $\mathrm{Cd}$, and $\mathrm{Hg}$ was associated with an increase of cytotoxicity, Hsp70 protein and mRNA in a time- and dose-dependent manner. ROS generation was detected by ESR spectroscopy and confocal microscopy. Induction of Hsp70 protein expression was inhibited by catalase and NAC. These results suggest that cellular injury caused by As, $\mathrm{Cd}$, and $\mathrm{Hg}$ is mediated through ROS generation resulting in the expression of Hsp70. Therefore, Hsp70 may prove to be a sensitive biomarker for As, Cd, and $\mathrm{Hg}$ exposure with correlative measurements of other biomarkers of oxidative stress in human serum.

Extensive studies were undertaken in human serum samples obtained from welders and unexposed workers. Welding generates fumes that contain many toxic metals and several toxic gases. We investigated the effects of welding fumes on correlates of oxidative stress in serum of asymptomatic shipyard welders. Blood samples were collected from 197 welders and 150 unexposed office workers matched for age, sex and smoking. The serum was assayed for total protein, albumin, total antioxidant, manganese superoxide dismutase, aconitase, glutathione peroxidase (GPx), Hsp70, isoprostane, and ROS. Changes caused by welding were evaluated in three groups based on exposure duration i.e., 1-10, 11-20 and 21+ years of work. Welding was associated with increase in serum protein, GPx, aconitase, ROS generation and isoprostane levels compared to controls. The results suggest that welding exposure can cause oxidative stress in workers of significant magnitude to be measured by serum biomarkers. 


\section{DEDICATION}

I wish to dedicate this work in appreciation to the many excellent teachers that I have had throughout the course of my education. I would like to express my sincere thanks and appreciation to my beloved wife, Myunghee, for all the support and patience; my parents, Ilwoong Han and Youngok Lee; my father-in-law, Shiyoung and mother-in-law Jongnam Lee; my lovely daughters, Sarah and Deborah; my sisters, brothers-in-law and sisters-in-law. I would like to thank my church members and coworkers in Morgantown and also very grateful to those named and unnamed, who helped and encouraged me throughout this study. 


\section{ACKNOWLEDGEMENTS}

The author wishes to thank:

Dr. Joginder Nath, chairperson of Genetics Program, for giving me an opportunity to complete my graduate studies, as well as for encouraging me to finish my graduate study.

Dr. Vincent Castranova for his exceptional talent as a branch chief and a researcher.

Dr. Sharon Wenger for her outstanding Human Genetics course through which I learned a lot and for her participation in my committee.

Dr. Dan Panaccione for his kind instruction and generosity.

Dr. Val Vallyathan for offering an excellent project, as well as mentoring, and encouraging as my research advisor. 


\section{TABLE OF CONTENTS}

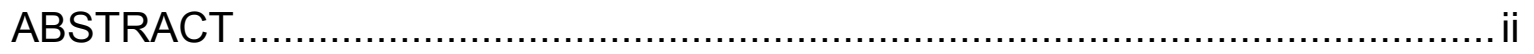

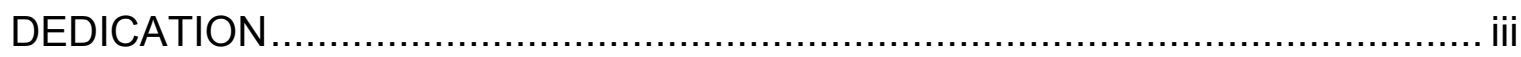

ACKNOWLEDGEMENTS ...................................................................... iv

TABLE OF CONTENTS $\ldots \ldots \ldots \ldots \ldots \ldots \ldots \ldots \ldots \ldots \ldots \ldots \ldots \ldots \ldots \ldots \ldots \ldots \ldots \ldots \ldots \ldots \ldots$

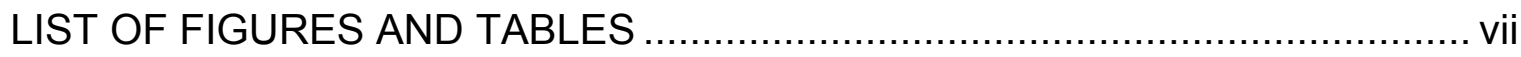

GENERAL INTRODUCTION AND REVIEW OF LITERATURE ....................

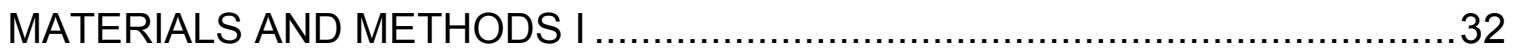

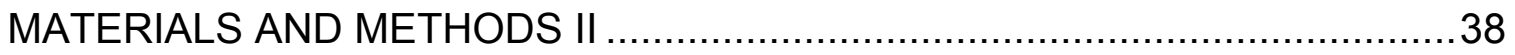

CHAPTER I: COMPARATIVE CYTOTOXICITY OF METALS AND THEIR CORRELATION WITH FREE RADICAL GENERATION, AND HEAT SHOCK PROTEIN EXPRESSION IN A HUMAN BRONCHIAL EPITHELIAL CELL LINE, BEAS-2B........47

CHAPTER II: HSP70 EXPRESSION AND REACTIVE OXYGEN SPECIES GENERATION IN HUMAN BRONCHIAL CELL LINE, BEAS-2B, CAUSED BY EXPOSURE TO ARSENIC. 61

CHAPTER III: HSP70 EXPRESSION AND REACTIVE OXYGEN SPECIES GENERATION IN HUMAN BRONCHIAL CELL LINE, BEAS-2B, CAUSED BY EXPOSURE TO CADMIUM.

CHAPTER IV: HSP70 EXPRESSION AND REACTIVE OXYGEN SPECIES GENERATION IN HUMAN BRONCHIAL CELL LINE, BEAS-2B, CAUSED BY

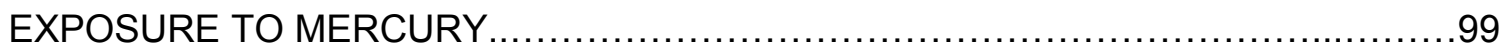


CHAPTER V: CORRELATES OF OXIDATIVE STRESS AND FREE RADICAL ACTIVITY IN THE SERUM OF ASYMPTOMATIC SHIPYARD WELDERS ............116

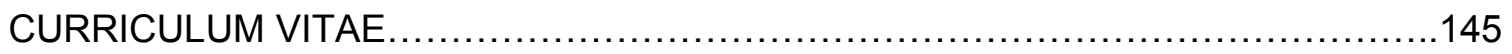




\section{LIST OF FIGURES AND TABLES}

\section{CHAPTER I}

Figure 1. MTT cytotoxicity test in BEAS-2B cells by metal exposure $\ldots \ldots \ldots \ldots \ldots \ldots \ldots 2$

Figure 2. Apoptosis of BEAS-2B cells determined by Hoechst dye .....................53

Figure 3. Hsp70 protein detection by Western blotting ..............................54

Figure 4. Effect of actinomycin D on Hsp70 protein expression in BEAS-2B cells

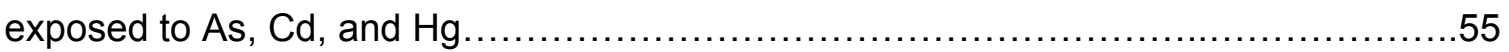

Figure 5. Comparative ESR spectra obtained from BEAS-2B cells exposed to As, Cd, Cr,

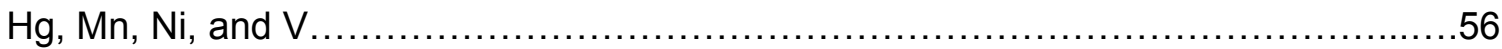

\section{CHAPTER II}

Figure 6. Cytotoxicity of As to BEAS-2B cells determined by the MTT assay..........68

Figure 7 . Hsp70 protein detection by Western blotting during recovery periods..........69

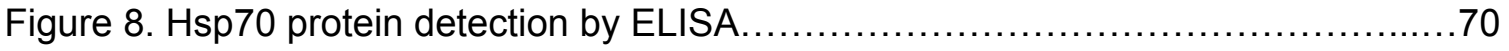

Figure 9. RT-PCR analysis of mRNA from BEAS-2B cells exposed to As..............71

Figure 10. Effect of antioxidants and other reagents on As-induced Hsp70 protein

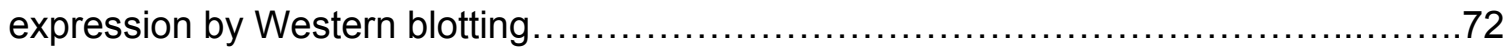

Figure 11. ESR spectra generated by DMPO/॰OH adducts obtained from BEAS-2B cells

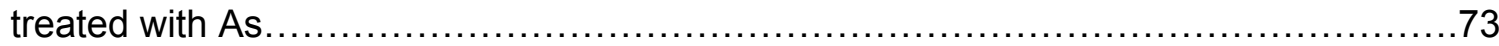

Figure 12. Detection of intracellular $\mathrm{H}_{2} \mathrm{O}_{2}$ and ${ }^{\circ} \mathrm{O}_{2}^{-}$generation by exposure to As using confocal microscopy. 
Figure 13. Lipid peroxidation detection by 8-isoprostane ELISA method

\section{CHAPTER III}

Figure 14. Cytotoxicity of Cd to BEAS-2B cells determined by the MTT assay......... 87

Figure 15. Hsp70 protein detection by Western blotting during recovery periods. .88

Figure 16. Hsp70 protein detection by ELISA. .89

Figure 17. RT-PCR analysis of mRNA from BEAS-2B cells exposed to $\mathrm{Cd}$. .90

Figure 18. Effect of antioxidants and other reagents on Cd-induced Hsp70 protein expression by Western blotting. 91

Figure 19. ESR spectra generated by DMPO/'OH adducts obtained from BEAS-2B cells treated with $\mathrm{Cd}$.

Figure 20. Detection of intracellular $\mathrm{H}_{2} \mathrm{O}_{2}$ and $\mathrm{O}_{2}{ }^{-}$generation by exposure to $\mathrm{Cd}$ using confocal microscopy.

\section{CHAPTER IV}

Figure 21. Cytotoxicity of $\mathrm{Hg}$ to BEAS-2B cells determined by the MTT assay.........105

Figure 22. Hsp70 protein detection by Western blotting during recovery periods........106

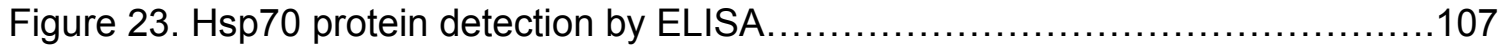

Figure 24. RT-PCR analysis of mRNA from BEAS-2B cells exposed to $\mathrm{Hg} \ldots \ldots \ldots \ldots . . . .108$

Figure 25. Effect of antioxidants and other reagents on Hg-induced Hsp70 protein expression by Western blotting..... 109 
Figure 26. ESR spectra generated by DMPO/'OH adducts obtained from BEAS-2B cells treated with $\mathrm{Hg}$. .110

Figure 27. Detection of intracellular $\mathrm{H}_{2} \mathrm{O}_{2}$ and $\mathrm{O}_{2}{ }^{-}$generation by exposure to $\mathrm{Hg}$ using confocal microscopy.

\section{CHAPTER V}

Table I. Demographic characteristics of controls. 123

Table II. Demographic characteristics of all welders in this study 124

Table III. Metal concentrations $\left(\mathrm{mg} / \mathrm{m}^{3}\right)$ in the ambient air at welding sites. .125

Table IV. Demographic characteristics of welders based on exposure duration 126

Figure 28. Serum concentrations of total proteins in controls and welders. 127

Figure 29. Serum albumin levels in controls and welders.... 128

Figure 30. Total antioxidant status in the serum of controls and welders 129

Figure 31. Serum GPx activity in the serum of controls and welders.... 130

Figure 32. Mn-SOD in the serum of controls and welders. .131

Figure 33. Aconitase activity in the serum of controls and welders....

Figure 34. Chemiluminescence in the serum of controls and welders. 133

Figure 35. Lipid peroxidation in the serum of controls and welders .134

Figure 36. Comparison of all controls with welders showing major differences in the increase of certain correlates of oxidative stress in the serum 135 


\section{GENERAL INTRODUCTION AND REVIEW OF LITERATURE}

A number of toxic heavy metals such as arsenic (As), chromium (Cr), cadmium $(\mathrm{Cd})$, mercury $(\mathrm{Hg})$, nickel $(\mathrm{Ni})$, vanadium $(\mathrm{V})$, and manganese $(\mathrm{Mn})$ are widely used in industries and are present in high levels in occupational and environmental ambient air. Exposure to these metals is associated with several adverse health effects in humans. Although many adverse health effects have been known, heavy metals are still used in a wide area of industries and exposure to heavy metals continues (1).

\section{Arsenic}

Arsenic is a naturally occurring element widely distributed in the soil, water and food (2-6). From available epidemiologic and experimental data, the International Agency for Research on Cancer (IARC) concluded that arsenic is a human carcinogen (2-6). Arsenic exposure causes many diseases, such as, cancer of the lung, skin and bladder, and cardiac abnormalities (7-10). Increased incidence of urinary bladder, kidney and liver cancer have also been reported in populations consuming arseniccontaminated drinking water in Argentina, Chile, India, Japan and Taiwan (11-19). Smelting of non-ferrous metals and fossil fuel combustion are two major sources for contamination of air, soil, and water (1). The National Institute for Occupational Safety and Health (NIOSH) estimated in a survey of 1980-1983 approximately 1.5 million industrial workers are potentially exposed to arsenic in different occupations of

manufacturing and processing in the United States (17). Occupational exposure to arsenic occurs in smelting of ores for cobalt, gold, lead, nickel, zinc and other metals. Exposure to gallium arsenide in microelectronic industry, wood preserving industry, pesticide industry and agriculture are other major sources of occupational exposure. Anthropogenic emissions of arsenic are estimated to be 23,600 tons per year on a global 
basis (5). Chronic exposure to high levels of arsenic mainly through food and water has been shown to be associated with increased incidence of skin and urinary cancers. Occupational and environmental exposure to arsenic also causes characteristic skin cancers and pulmonary cancers in exposed populations (4).

Arsenic exists in many forms. Inorganic trivalent and pentavalent forms are the most important types causing human diseases $(17,20)$. The molecular mechanisms of arsenic toxicity leading to carcinogenesis are not yet fully understood. Current evidence indicates that arsenic-induced ROS acts on signaling pathways, promoting cell proliferation rather than causing direct DNA damage $(21,22)$. ROS induced by toxic metals are capable of causing an oxidative stress that can damage or modulate a variety of cellular macromolecules and mechanisms (23). Arsenic-induced ROS generated during cellular reactions include hydrogen peroxide $\left(\mathrm{H}_{2} \mathrm{O}_{2}\right)$, superoxide anion $\left(\cdot \mathrm{O}_{2}{ }^{-}\right)$, singlet oxygen $\left(\mathrm{O}^{1}\right)$, and hydroxyl radical $(\cdot \mathrm{OH})$, which in turn activate or inactivate cellular molecular mechanisms involved in protecting the cells from death, which might lead to carcinogenesis $(24,25)$.

\section{Cadmium}

Cadmium is a common occupational and environmental pollutant. Cadmium and cadmium containing compounds are well documented human and animal carcinogens (26). Human exposure to cadmium occurs mainly through inhalation of emission from non-ferrous smelters and other industrial operations, cigarette smoke and diet (27). Cadmium is primarily used in batteries, pigments, electroplating, stabilizing plastics, in alloys and anti-corrosion agents (1,3). The NIOSH survey conducted from 1981 to 1983 estimated that 153,486 workers are exposed to cadmium at occupational workplaces (17). Cadmium exposure leads to a variety of harmful health effects, and diseases. 
Human exposure may cause accumulation in human tissues primarily in lung, liver, kidney, and skeletal systems $(1,28)$. In addition, it has been shown that acute exposure of the respiratory track to cadmium caused several diseases such as pulmonary inflammation, edema, cytosis, and proliferation of interstitial and epithelial cells $(29,30)$. Cadmium is a known human carcinogen based on its characteristic as a lung carcinogen, and is a potent carcinogen in rodents which is supported by animal experiments $(26,31)$. It is also believed that occupational exposure to cadmium is associated with cancers in the lung, kidney, and prostate (32). Cadmium has a characteristic long half life which makes its toxic effects last long (33).

The precise mechanisms involved in cadmium-induced disease development are not fully defined. It has been demonstrated that cadmium exposure induces a number of genes (34). These genes include cell defense and repair proteins, signal transduction proteins as well as oncogenes. Also, cadmium is known to induce stress response proteins including metallothionein (MT), and heat shock protein (Hsp) (35). Heme oxygenase-1 (HO-1), and Hsp72 were highly inducible on PCR-based subtraction analysis in cadmium-exposed rat lung type 2 epithelial cells (36). Heat shock protein 10, $40,60,70,89$ and MT-2 mRNA were found to be induced by cadmium exposure in COS-7 cells by suppression subtractive hybridization (SSH) technique (37). On the other hand, induction of both oncogenes and tumor suppressor genes are found by cadmium exposure in a variety of cells. Oncogenes such as c-myc, c-fos, and c-jun are found to be induced as well as tumor suppressor genes, for example p53 (38). Cadmium exposure also alters the expression of antioxidant genes such as catalase, and superoxide dismutase (SOD); transcription factors such as metal regulatory transcription factor-1 (MTF-1), nuclear factor kB (NF-kB), upstream stimulator factor (USF) (32). The precise molecular mechanism involved in cadmium toxicity and cellular alterations and expression of these genes associated with carcinogenicity are not fully 
understood. However, current evidence shows that ROS may play an important role in triggering several molecular events important in carcinogenesis. It has been shown that cadmium induces oxidative stresses inside and outside the cells through the production of ROS (39). This cadmium-induced production of ROS is thought to be through a mitochondrial dysfunction and not through a Fenton-like reaction $(40,41)$. Although the mechanisms involved in cadmium-induced ROS generation is not yet fully understood, indirect evidence indicates ROS induced alterations in the cytoskeleton of the cells and the upregulation of redox-sensitive transcription factor AP-1 $(38,42)$. Other possible mechanisms implicated in cadmium toxicity and alteration of gene expression are the increase in intracellular $\mathrm{Ca}^{2+}$ and changes in intracellular signaling cascade, activation of protein kinases, and DNA-cytosine methylation (32).

\section{Mercury}

Mercury is ubiquitous in low level in environment and occupations, but is a heath hazard in industries and environment. Dental amalgams, vaccine preservatives, and mercury-containing foods are three other major sources of human exposure $(43,44)$. There are three biologically important forms of mercury which are elemental $\left(\mathrm{Hg}^{0}\right)$, organic $(\mathrm{MeHg})$, and inorganic $\left(\mathrm{HgCl}_{2}\right)$ mercury $(44,45)$. The chemical and physical forms of mercury determine its toxicity and metabolism. Elemental mercury is a silver liquid at room temperature, for example as used in thermometers, barometers, and instruments. Its vapor is easily absorbed in the lung, but is poorly absorbed through skin or gastrointestinal $(\mathrm{Gl})$ track $(1,44,45)$. On the other hand both inorganic and organic mercury are absorbed through lung, skin and GI track $(1,44,45)$. It is believed that inorganic mercury may cause lung damage, kidney injury, and allergies (1). Inorganic mercury can be converted to more stable organic forms by microorganisms in aquatic environment. Organic mercury, for example methyl mercury, leads to nervous system 
damage such as Minamata disease which was caused by consumption of methyl mercury-containing fish $(1,43,44)$.

In the general population, however, both mercury-containing foods and dental amalgams are the primary sources of mercury exposure. The most important biological effect of mercury exposure is the neurological damage. Methyl mercury absorbed in $\mathrm{Gl}$ track is distributed by blood circulation throughout the body where the methyl mercury binds with sulfhydryl $(\mathrm{SH})$ groups of protein in tissues or cells $(44,46,47)$. Also, absorbed methyl mercury can cross the blood-brain barrier through amino acid carriers and accumulate in the brain resulting in major neurological damage (47).

Both elemental and inorganic mercury are usually used in industrial settings. Occupational exposure to mercury occurs mainly in chloralkali industries where mercury is used for the manufacture of electrodes, from fossil fuel emissions, and in dental clinics where dental amalgam is used (1). Elemental mercury is more toxic to human health when it is volatilized to vapor. Vaporized mercury can be inhaled and absorbed by lung and skin, respectively. Its toxic effects are associated with oxidization to mercuric ions and binding to $\mathrm{SH}$ groups (44). It has been demonstrated in animal studies that mercury vapor can damage CNS and lung $(48,49)$ and can induce kidney damage, and neurological injury in humans $(50,51)$. Several epidemiological studies have been carried out to observe the biological changes in humans who are occupationally exposed to mercury. In very low levels, metallic mercury led to subtle impairment of circulating monocytes and natural killer cells (52). Lipid peroxidation was increased in erythrocytes of elemental mercury exposed workers while the activity of antioxidant enzymes such as superoxide dismutase (SOD) and glutathione peroxidase (GPx) was decreased (53). Several cellular studies have shown alterations in gene expression by mercury exposure. In renal epithelial cells, c-fos gene was markedly increased in analysis by RT-PCR and Western blott analysis (54). The synthesis of cellular stress-induced molecular 
chaperones was enhanced by exposure to mercury (55). Both Hsp70 and Hsp90 synthesis were increased in chick embryos (56), and Hsp70 synthesis was enhanced in human monocytes (57), in mouse adult neuronal stem cells (58), and in rat kidney cells (59). Alteration of gene expression caused by elemental mercury vapor exposure was well studied in rat lung by Liu et al. (60). In the microarray analysis, a number of genes related to inflammatory responses, such as chemokines, tumor necrosis factor-alpha (TNF- $\alpha$ ), TNF-receptor-1, interleukin-2 (IL-2), IL-7, prostaglandin, and E2 receptor were increased. Also, heat shock proteins, glutathione S-transferases, metallothionein, and thioredoxin peroxidase were increased in response to mercury vapor exposure. Transcription factor c-jun/AP-1 and PI3-kinases was suppressed, while the expression of protein kinase $\mathrm{C}$ was increased (60). In rat kidney epithelial cells, both NF-KB activation and DNA binding activity were attenuated (61).

Oxidative stress has been implicated as a mechanism of mercury-induced cell toxicity and injury. Mercury exposure induces the generation of ROS in cultured mammalian cells $(55,62)$ and in animal experiments $(63,64)$. Mercury can alter calcium homeostasis and calcium is assumed to play a role in the regulation of ROS production $(65,66)$. Another hypothesis is that mercury is able to deplete free $\mathrm{SH}$ groups, thiolcontaining antioxidants, and enzymes $(40,63,64)$.

\section{Chromium}

Chromium is abundant in the environment. Chromium exists primarily in two states; trivalent form, $\mathrm{Cr}(\mathrm{III})$, and hexavalent form, $\mathrm{Cr}(\mathrm{VI})$ (67-70). Chromium compounds, specifically $\mathrm{Cr}(\mathrm{VI})$ are used in many different industries including leather tanning, welding, pigment production, electroplating, and as a catalyst (68, 69). However, $\mathrm{Cr}(\mathrm{III})$ is considered as an essential micronutrient $(71,72)$. The main human exposure to $\mathrm{Cr}(\mathrm{VI})$ is through inhalation leading to a variety of respiratory diseases (69). 
Generally, $\mathrm{Cr}(\mathrm{VI})$ is more toxic than $\mathrm{Cr}(\mathrm{III})$ based on its chemical properties such as absorption and potential for oxidant generation. $\mathrm{Cr}(\mathrm{VI})$ can enter cells by anion transportation and subsequently reduced to its intermediates, $\operatorname{Cr}(\mathrm{V}), \operatorname{Cr}(\mathrm{IV})$, or $\operatorname{Cr}(\mathrm{III})(73$, 74). This unique property confers $\mathrm{Cr}(\mathrm{VI})$ a strong oxidant effect via the binding of intermediates to cellular proteins. Reduction of $\mathrm{Cr}(\mathrm{VI})$ to $\mathrm{Cr}(\mathrm{III})$ can produce reactive intermediates and ROS which are associated with DNA damage, lipid peroxidation, and activation of transcription factors (75-77). A number of research studies have been published documenting the toxicity and carcinogenicity of $\mathrm{Cr}(\mathrm{VI})$. $\mathrm{Cr}(\mathrm{VI})$-containing compounds are classified as Group I human carcinogens by IARC, and US EPA $(78,79)$. Alterations in gene expression caused by $\mathrm{Cr}(\mathrm{VI})$ exposure have been extensively studied in both in vitro and in vivo animal models. $\mathrm{Cr}(\mathrm{VI})$ exposure can alter a number of genes related to oxidative stress, cell cycle regulation, signal transduction, cell cycle, apoptosis, and metabolism (68). The degree of both alteration of gene expression and DNA damage caused by $\mathrm{Cr}(\mathrm{VI})$ exposure may direct cells to choose either carcinogenesis or death. Apoptosis caused by $\mathrm{Cr}(\mathrm{VI})$ exposure involves the activation of both extrinsic (death receptor) and intrinsic (mitochondrial) pathways. The proteins (c-Flip and Bcl-2) that regulate these pathways are modulated by ROS. Therefore $\mathrm{Cr}(\mathrm{VI})$-induced generation of ROS play an important role in carcinogenesis.

\section{Nickel}

Nickel is widely distributed in nature and in industries (69). Occupational exposure to nickel occurs in nickel mining, smelting, refining, alloy production, electroplating, welding, nickel-cadmium batteries and oil combustion in power plant ( 80 , 81). Nickel and nickel compounds are known human carcinogens based on animal, human and mechanistic studies and IARC reported certain nickel compounds as carcinogenic excluding metallic nickel and nickel alloys (78). Both inhalation and 
ingestion are primary routes for human exposure to nickel. Consequently, major health effects from occupational exposure to nickel are associated with nasal and lung disease (78). Water-insoluble nickel compounds are believed to be Group I human carcinogen (78). Nickel is considered as a mutagen which causes DNA damage including DNA methylation, histone deacetylation, DNA-protein cross-links, oxidative DNA base damage, and chromatin condensation $(23,80,81)$. Alteration of cell signaling pathway by nickel has been reported. Several well-known genes including hypoxia-inducible transcription factor (HIF-1), NF-kB, p53 and retinoblastoma (Rb) were induced by exposure to nickel (80). The ROS generation has been considered a major mechanism involved in nickel toxicity and carcinogenicity (80-82). Nickel produces ROS through Fenton-like reaction or binding to certain ligands in the cell. This binding oxidizes the $\mathrm{Ni}^{2+}$ to $\mathrm{Ni}^{3+}$ and such redox cycling results in generation of $\mathrm{ROS}(80,82)$. ROS generated by nickel may play a role in the activation of transcription factors, DNA damage, depletion of antioxidants, and GSH (83).

\section{Vanadium}

Vanadium is widely used in industries and occupational exposure is common in petrochemical, mining, steel industries, and fossil fuel combustion $(84,85)$. Major health effects from occupational exposure to vanadium are confined to the respiratory system through inhalation. Exposure to vanadium results in upper and lower respiratory track irritation, and lung inflammation (84-86). Pulmonary alveolar macrophages (AM) may play an initial role in the toxic effect of exposure to vanadium. AMs exposed to vanadium release proinflammatory cytokines which lead to pulmonary inflammation (85, 86). These proinflammatory cytokines include IL-6, IL-8, TNF- $\alpha$, prostaglandin E2 (87, 88). It has been reported that vanadium exposure can produce ROS from cells at an enhanced level $(86,88-90)$. This increased generation of ROS may contribute to 
activation of some genes, such as pro-apoptotic protein, p53, transcription factor and nuclear factor of activated T cells (NFAT) $(89,90)$. Vanadium-induced apoptosis was well reviewed by Chen et al. (91). Vanadium treatment showed a variety of apoptosis characteristics including caspase activation, increase of mitochondrial permeability, and the release of cytochrome $\mathrm{C}$ in lymphoid cells. In other cells, however, vanadium exposure caused anti-apoptotic gene expression such as Akt, and PI3 kinase.

\section{Manganese}

Manganese is an essential trace element found in the body, while excessive exposure to manganese can result in neural damage, reproductive, and immune system dysfunction (92-94). Manganese is used in many different industries including production of paint pigment, dry cell batteries, glass, ceramics, welding, and mining of manganese ores (92-94). Manganese may cause Parkinson-like disease by alteration of dopaminergic functions in the basal ganglia of brain (95). Although the mechanism of manganese neurotoxicity is not well elucidated, manganese-induced oxidative stress has been proposed as a mechanism in neurotoxicity $(93,94,96)$. Also, it has been shown that manganese can produce $\operatorname{ROS}(97,98)$. The toxicity caused by manganese is associated with oxidative stress which leads to cellular damage and modulation of signal transduction such as AP-1 and NF-kB activation (99-101).

\section{Occupational Exposure to Welding Fume}

Welding generates fumes that may contain many toxic metals, such as iron, manganese, chromium, nickel, and several toxic gases, such as carbon monoxide, ozone and nitrogen oxides. These metals and gases generated in industrial operations are ubiquitous pollutants at occupational worksites and environment with the potential to

produce adverse health effects. It was estimated that approximately 800,000 to 
$1,000,000$ workers are employed as full time welders on a worldwide basis $(102,103)$. Recent estimates by the Bureau of Labor Statistics showed that more than 361,970 workers were employed as welders, solderers, brazers or in other welding related work in various industries in the United States during 2002, and more than 2,000,000 workers are involved in some type of welding work on a worldwide basis (104). The concentration and composition of metal particulates and gases generated at welding operations are largely dependent on the composition of the filler metals, base materials, welding processes, and use of flux. Fumes generated from mild steel welding usually contain $\sim 80 \%$ or more of iron and some manganese, while stainless steel electrodes contain $20 \%$ chromium and $10 \%$ nickel (103). During welding processes, shielding gases are provided to reduce oxidative reactions and to protect the resultant weld (105). Carbon dioxide, helium, or argon are the inert shielding gases commonly used which may increase the production of toxic gases, such as nitrogen oxide, ozone and carbon monoxide, through several different reactions. The increased incidence of adverse respiratory health effects in welders reported in epidemiologic studies were mostly attributed to differences in welding materials, processes, exposure severity and ventilation (106-110). Welding fumes can cause a variety of diseases from minor syndromes, such as headache, nausea and metal fume fever, to severe health effects, such as occupational asthma, pneumoconiosis, bronchitis, lung cancer and manganism (78, 103, 106-108). Based on epidemiologic and animal studies, the International Agency for Research on Cancer concluded that welding fumes were "possibly carcinogenic" to humans (78). This was further supported by extensive studies on hexavalent chromium and nickel carcinogenesis in animal and epidemiologic studies (67, $74,78,111-113)$. Although the mechanisms involved are still not very well understood, it is generally believed that hexavalent chromium is reduced to its lower oxidation states within the cell with the potential to generate ROS $(74,114)$. Chromium and nickel 
compounds are also believed to cause cancers through their mutagenic and chromosomal aberration potential $(112,113,115)$. Although iron, the major component of fumes, is essential in the body, excess exposure to iron can also cause several adverse health effects (116).

It has been shown that chromium, nickel, and iron can produce ROS such as hydroxyl radicals $\left({ }^{\circ} \mathrm{OH}\right)$, superoxide anion $\left({ }^{\circ} \mathrm{O}_{2}^{-}\right)$, singlet oxygen $\left(\mathrm{O}^{1}\right)$ and $\mathrm{H}_{2} \mathrm{O}_{2}(40,74)$. This increased production of ROS can trigger several key signaling events to provoke adverse biochemical and molecular abnormalities in the target cells leading to a disease state.

\section{Heat Shock Protein}

Heat shock proteins (Hsp) are a group of molecular chaperone proteins that have been shown to be induced by exposure of cells to a variety of stresses (117-120). Stresses that induce Hsps can be divided into three groups. These three include environmental and physical stresses (heat shock, UV radiation, heavy metals, oxidants, amino acid analogues), physiological stresses (hormone, growth factors, cell cycle, oxidative stress, ischemia), and pathological states (infections, glucose starvation, inflammation) $(119,121)$. Hsps are localized in several different cell compartments including cytosol, nucleus, mitochondria, and ER (122). Some of the hsps are constitutively expressed at low levels to maintain the cell homeostasis under normal conditions. This function includes folding, assembly or disassembly, and translocation of newly synthesized proteins $(123,124)$.

Hsp is a large super family and can be classified based on their molecular mass from 10 to $170 \mathrm{kDa}(118,119,122)$. There are about eight family members referred to as Ubiquitins, Small HSPs, HSP10, 40, 60, 70, 90, and 110. The most well-known HSP70 family includes several family members; the inducible form of Hsp70, and the 
cognate forms of Hsc70, Hsp75, and Hsp78 $(118,119,122)$. Hsp70 protein is localized in cytosol or nucleus where it is involved in protein folding or cytoprotections. Hsp70 gene is comprised of 2,440 base pairs containing a 212 base pair leader sequence and a 242 base pair 3' untranslated region $(122,125)$. Hsp70 protein has two conserved domains; an ATP-binding domain which binds and hydrolyzes ATP, and a peptidebinding domain which binds to target proteins (126). These two functional domains are necessary to recognize and repair unfolded or partially folded proteins (118).

In eukaryotic cells, heat shock factors (HSF) are the major transcription regulator in the regulation of hsp genes (119). There are four different HSFs found in human cells; HSF1, HSF2, HSF3, and HSF4. The four different HSFs have different transcription mechanisms depending on types of stress or cells (119). HSFs contain a conserved N-terminal DNA binding domain and C-terminal transactivation domain (127). HSF1 is the most well documented transcription factor among four different HSFs. Under normal conditions, HSF1 is localized in the cytosol or nucleus as an inactive monomer, however, under stress conditions, it moves to the nucleus and forms an active trimer which binds to heat shock elements (HSE) located in the promoter region of the Hsp genes to induce the gene transcription $(119,128-130)$. It has been shown that the activity of HSF1 can be modulated by many different factors. Auto-regulation by Hsp70 or Hsp90 can suppress the activity of HSF1 while a variety of physiological and environmental stresses such as heat, ROS, heavy metals, and denatured proteins enhance the activity of HSF1 $(119,131-135)$.

The ROS generated by metal exposure may contribute to enhance the expression of Hsps at least in part (123). The mechanisms involved in ROS generation by actions of metals include redox reactions, depletion of antioxidants, and binding to SH groups on proteins $(40,136)$. 
Hsps are involved in a variety of cellular and molecular events. Hsps have been extensively studied in the relation of cancer, apoptosis, and signal transduction. It has been shown that Hsp70 suppresses stress-induced apoptotic cell death. Many reports showed that Hsp70 blocks the key regulators of apoptotic signaling cascades such as activation of cascade, and c-Jun N-terminal kinases/stress-activated protein kinases (JNK/SAPK) (137-142).

Interestingly, a number of tumor cells show increased level of Hsps (143-146). It is assumed that the oncogenesis is caused by the role of Hsp as a cell cycle system regulator, a mitogen-activated signal cascade controller, and a negative regulation of apoptosis (145). However, it is not known whether the elevation of Hsp70 is either a cause or a consequence of oncogenesis (144).

As stated earlier, Hsps induced by stresses function as a cytoprotectant whose functions are refolding and reaggreation of denatured proteins $(133,147)$. However, cells exposed to extreme or prolonged stresses undergo cell death by necrosis or apoptosis despite higher concentrations of induced Hsps. Therefore, expression of Hsp could be used as a sensitive biomarker when cells are placed under conditions of stress. Expression of Hsp70 has been proposed as a potential marker for the presence of deleterious agents in soils (148), seaweed (149), mussels and fish tissue (150). Also, Hsp70 has been proposed to be a sensitive indicator of cadmium and nickel-induced metal toxicity in the cultured human cells (151).

There are some reports of Hsps release while cells are under conditions of stress or disease $(134,152,153)$. Hsp70 could be released into the peripheral circulation providing a high Hsp70 level in serum by acute exercise (134). Therefore, monitoring Hsp70 in industrial worker's blood exposed to toxic heavy metals may prove to be a sensitive biomarker for exposure. 


\section{Objective of Study}

Heat shock proteins (Hsps) are a family of highly conserved proteins that are induced by a number of agents that cause stress including toxic heavy metals. Hsp70 expression has been reported to be an early and sensitive biomarker of cell stress. A number of toxic heavy metals such as arsenic (As), cadmium (Cd), mercury $(\mathrm{Hg})$, chromium $(\mathrm{Cr})$, nickel $(\mathrm{Ni})$, vanadium $(\mathrm{V})$, and manganese $(\mathrm{Mn})$ are widely used in occupational settings and exposure to these metals is associated with the development of pulmonary disease. Therefore, Hsp70 expression was observed in human bronchial epithelial cells exposed to metals to test the possibility as a biomarker. Also, Hsp70 induction mechanism such as oxidative stresses was elucidated.

Welding generates fumes contain many toxic materials and several toxic gases. The purpose of next study was to investigate the effects of welding fumes on correlates of oxidative stress in the serum of asymptomatic shipyard welders. The serum was assayed on a blind basis for total protein, albumin, total antioxidant capacity, manganese superoxide (Mn-SOD), aconitase, glutathione peroxidase (GPx), Hsp70, isoprostane, and ROS generation potential. To evaluate the changes caused by exposure to welding fumes, the welder's group was divided into three groups based on years of work in welding from 1-10 years, 11-20 years and 21 or more years of welding exposure. 


\section{REFERENCES}

1. Jarup L. Hazards of heavy metal contamination. Br Med Bull. 2003;68:167-82.

2. International Agency for Research on Cancer Monographs on the Evaluation of Carcinogenic Risks to Humans: 23: 39-324, 1980.

3. International Agency for Research on Cancer Monographs on the Evaluation of Carcinogenic Risks to Humans: Supplement 7, Overall Evaluations of Carcinogenicity: An Updating of IARC Monographs. IARC Scientific Publications, IARC Lyon, Vol. 1-42, pp. 100-106, 1987.

4. Basu A, Mahata J, Gupta S, Giri AK. Genetic toxicology of a paradoxical human carcinogen, arsenic: a review. Mutation Research 488: 171-194, 2001.

5. Chan PC, Huff J. Arsenic carcinogenesis in animals and in humans. Mechanistic, experimental and epidemiological evidence. Environ Carcinogen Ecotoxicol Rev C15: 83-122, 1997.

6. Huang C, Li J, Ding M, Wang L, Shi X, Castranova V, Vallyathan V, Ju G, Costa M. Arsenic-induced NFkB transactivation through Erks- and JNKs-dependent pathways in mouse epidermal JB6 cells. Mol Cell Biochem 222: 29-34, 2001.

7. Huang C, Li J, Ding M, Costa M, Castranova V, Vallyathan V, Ju G, Shi X. Transactivation of RARE and GRE in the cellular response to arsenic. Mol Cell Biochem 222: 119-125, 2001.

8. Chen F, Lu Y, Zhang Z, Vallyathan V, Ding M, Castranova V, Shi X. Opposite effects of NF-kB and c-Jun N-terminal kinase on p53-independent GADD45 induction by arsenic. J Biol Chem 276: 11414-11419, 2001.

9. Simeonova PP and Luster MI. Mechanisms of arsenic carcinogencity: genetic or epigenetic mechanisms? J Environ Pathol Oncol 19: 281-286, 2000. 
10. Pott WA, Benjamin SA, Yang RSH. Pharmacokinetics, metabolism and carcinogenicity of arsenic. Rev Environ Contam Toxicol 165-214, 2001.

11. Hopenhayn-Rich C, Biggs ML, Fuch A, Bergoglio R, Tello EE, Nicoli H, Smith A. Bladder cancer mortality associated with arsenic in drinking water. Am J Epidemiol 7: 117-124, 1996.

12. Smith A, Goycolea M, Haque R, Biggs ML. Marked increase in bladder and lung cancer mortality in a region of Northern Chile due to arsenic in drinking water. Am J Epidemiol 147: 660-669, 1998.

13. Tsuda T, Babazono A, Yamamoto E, Kurumatini N, Mino Y, Ogawa T, Kishi Y, Aoyama $\mathrm{H}$. Ingested arsenic and internal cancer: a historical cohort study followed for 33 years. Am J Epidemiol 141: 198-209, 1995.

14. Chiou HY, Hsueh YM, Liaw KF, Horng SF, Chiang MH, Pu YS, Lin JSN, Huang CH, Chen CJ. Incidence of internal cancers and ingested inorganic arsenic: a sevenyear follow-up study in Taiwan. Cancer Res 55:1296-1300, 1995.

15. Mazumdar GDN, Santra A, Maity A, Das S, Ghosh A, Gupta JD, Chattopadhaya N. Clinical and pathological effect of drinking arsenic contaminated water in liver. Abstract, International Conf on Biomarkers for Toxicology and Molecular Epidemiology, CDC/ATSDR, Atlanta, GA, March 15-17, 2004.

16. Simeonova PP, Wang S, Toriuma W, Kommineni V, Matheson J, Unimye N, Kayama F, Harki D, Ding M, Vallyathan V, Luster MI. Arsenic mediates cell proliferation and gene expression in the bladder epithelium: Association with activating protein-1 transactivation. Cancer Res 60: 3445-3453, 2000.

17. National Institute for Occupational Safety and Health: Nation Occupational Exposure Survey (1980-1983). Department of Health and Human Services, Cincinnati, OH, 1984. 
18. Smith,A.H., Hopenhayn-Rich,C., Bates,M.N., Goeden,H.M., Hertz-Picciotto,I., Duggan,H.M., Wood,R., Kosnett,M.J. and Smith,M.T. Cancer risks from arsenic in drinking water. Environ Health Perspect 97: 259-267, 1997.

19. Bates,M.N., Smith,A.H. and Hopenhayn-Rich,C. Arsenic ingestion and internal cancers: a review. Am J Epidemiol 135: 462-476, 1992.

20. Lansdown ABG. Physiological and toxicological changes in the skin resulting from the action and interaction of metal ions. Crit Rev Toxicol 25: 397-462, 1995.

21. Cavigelli M, Li WW, Lin A, Su B, Yoshioka K, Karin M. The tumor promoter arsenite stimulates AP-1 activity by inhibiting a JNK phosphatase. EMBO 15: 6269-6279, 1996.

22. Hayes RB. The carcinogenicity of metals in humans. Cancer Causes Control 8: 371-385, 1997.

23. Kasprzak KS. Oxidative DNA and protein damage in metal-induced toxicity and carcinogenesis. Free Rad Biol Med 32: 958-967, 2002.

24. Kitchin KT. Recent advances in arsenic carcinogenesis: modes of action, animal model systems, and methylated arsenic metabolites. Toxicol Appl Pharmacol 172: 249-261, 2001.

25. Kessel M, Liu A, Xu A, Santella R, Hei TK. Arsenic induces oxidative DNA damage in mammalian cells. Mol Cell Biochem 234-235: 301-308, 2002.

26. International Agency for Research on Cancer, 1993. Beryllium, cadmium, mercury, and exposure in the glass manufacturing industry. In: International Agency for Research on Cancer Monographs on the Evaluation of Carcinogenesis Risks to Humans, vol. 58. IARC Scientific Publications, Lyon, pp. 119-237.

27. Trzcinka-Ochocka M, Jakubowski M, Razniewska G, Halatek T, Gazewski A. The effects of environmental cadmium exposure on kidney function: the possible influence of age. Environ Res. 2004 Jun;95(2):143-50. 
28. Gerhardsson L, Englyst V, Lundstrom NG, Sandberg S, Nordberg G. Cadmium, copper and zinc in tissues of deceased copper smelter workers. J Trace Elem Med Biol. 2002;16(4):261-6.

29. Bajpai R, Waseem M, Khanna AK, Kaw JL. Comparative pulmonary toxicity of cadmium and nickel: histopathological and bronchoalveolar lavage analysis. Indian J Exp Biol. 1999 Jun;37(6):541-5.

30. Bell RR, Nonavinakere VK, Soliman MR. Intratracheal exposure of the guinea pig lung to cadmium and/or selenium: a histological evaluation. Toxicol Lett. $2000 \mathrm{Apr}$ $3 ; 114(1-3): 101-9$

31. National Toxicology Program, 2000. Ninth report on carcinogens. National Toxicology Program, Research Triangle Park, NC, USA.

32. Waisberg M, Joseph P, Hale B, Beyersmann D. Molecular and cellular mechanisms of cadmium carcinogenesis. Toxicology. 2003 Nov 5;192(2-3):95-117.

33. Waalkes MP. Cadmium carcinogenesis. Mutat Res. 2003 Dec 10;533(1-2):107-20.

34. Wang Z, Templeton DM. Induction of c-fos proto-oncogene in mesangial cells by cadmium. J Biol Chem. 1998 Jan 2;273(1):73-9.

35. Gong Q, Hart BA. Effect of thiols on cadmium-induced expression of metallothionein and other oxidant stress genes in rat lung epithelial cells. Toxicology. 1997 May 16;119(3):179-91.

36. Hirano S, Kitajima H, Hayakawa T, Cui X, Kanno S, Kobayashi Y, Yamamoto M. PCR-based subtraction analyses for upregulated gene transcription in cadmiumexposed rat lung type 2 epithelial cells. Biochem Biophys Res Commun. 2003 Aug $15 ; 308(1): 133-8$.

37. Lee MJ, Nishio H, Ayaki H, Yamamoto M, Sumino K. Upregulation of stress response mRNAs in COS-7 cells exposed to cadmium. Toxicology. 2002 May 24;174(2):109-17. 
38. Joseph P, Muchnok TK, Klishis ML, Roberts JR, Antonini JM, Whong WZ, Ong T. Cadmium-induced cell transformation and tumorigenesis are associated with transcriptional activation of c-fos, c-jun, and c-myc proto-oncogenes: role of cellular calcium and reactive oxygen species. Toxicol Sci. 2001 Jun;61(2):295-303.

39. Bagchi D, Joshi SS, Bagchi M, Balmoori J, Benner EJ, Kuszynski CA, Stohs SJ. Cadmium- and chromium-induced oxidative stress, DNA damage, and apoptotic cell death in cultured human chronic myelogenous leukemic K562 cells, promyelocytic leukemic HL-60 cells, and normal human peripheral blood mononuclear cells. J Biochem Mol Toxicol. 2000;14(1):33-41.

40. Stohs SJ, Bagchi D. Oxidative mechanisms in the toxicity of metal ions. Free Radic Biol Med. 1995 Feb;18(2):321-36.

41. Wang Y, Fang J, Leonard SS, Rao KM. Cadmium inhibits the electron transfer chain and induces reactive oxygen species. Free Radic Biol Med. 2004 Jun $1 ; 36(11): 1434-43$

42. Cappelletti G, Maggioni MG, Candia Carnevali MD, Bonasoro F, Maci R. Dynamic changes in the state of actin polymerization in human alveolar cells exposed to the oxidant agent paraquat. Eur J Cell Biol. 1996 Nov;71(3):293-302.

43. Krantz A, Dorevitch S. Metal exposure and common chronic diseases: a guide for the clinician. Dis Mon. 2004 May;50(5):220-62.

44. Counter SA, Buchanan LH. Mercury exposure in children: a review. Toxicol Appl Pharmacol. 2004 Jul 15;198(2):209-30.

45. Gochfeld M. Cases of mercury exposure, bioavailability, and absorption. Ecotoxicol Environ Saf. 2003 Sep;56(1):174-9.

46. Castoldi AF, Coccini T, Ceccatelli S, Manzo L. Neurotoxicity and molecular effects of methylmercury. Brain Res Bull. 2001 May 15;55(2):197-203. 
47. Kerper LE, Ballatori N, Clarkson TW. Methylmercury transport across the bloodbrain barrier by an amino acid carrier. Am J Physiol. 1992 May;262(5 Pt 2):R761-5.

48. Moller-Madsen B. Localization of mercury in CNS of the rat. V. Inhalation exposure to metallic mercury. Arch Toxicol. 1992;66(2):79-89.

49. Yoshida M, Satoh M, Shimada A, Yasutake A, Sumi Y, Tohyama C. Pulmonary toxicity caused by acute exposure to mercury vapor is enhanced in metallothionein-null mice. Life Sci. 1999;64(20):1861-7.

50. El-Safty IA, Gadallah M, Shafik A, Shouman AE. Effect of mercury vapour exposure on urinary excretion of calcium, zinc and copper: relationship to alterations in functional and structural integrity of the kidney. Toxicol Ind Health. 2002 Sep;18(8):377-88.

51. Cordeiro Q Jr, de Araujo Medrado Faria M, Fraguas R Jr. Depression, insomnia, and memory loss in a patient with chronic intoxication by inorganic mercury. $J$ Neuropsychiatry Clin Neurosci. 2003 Fall;15(4):457-8.

52. Vimercati L, Santarelli L, Pesola G, Drago I, Lasorsa G, Valentino M, Vacca A, Soleo L. Monocyte-macrophage system and polymorphonuclear leukocytes in workers exposed to low levels of metallic mercury. Sci Total Environ. $2001 \mathrm{Apr}$ $10 ; 270(1-3): 157-63$.

53. Bulat P, Dujic I, Potkonjak B, Vidakovic A. Activity of glutathione peroxidase and superoxide dismutase in workers occupationally exposed to mercury. Int Arch Occup Environ Health. 1998 Sep;71 Suppl:S37-9.

54. Matsuoka M, Wispriyono $\mathrm{B}$, Igisu $\mathrm{H}$. Induction of c-fos gene by mercury chloride in LLC-PK1 cells. Chem Biol Interact. 1997 Dec 12;108(1-2):95-106.

55. De Flora S, Bennicelli C, Bagnasco M. Genotoxicity of mercury compounds. A review. Mutat Res. 1994 Feb;317(1):57-79. 
56. Papaconstantinou AD, Brown KM, Noren BT, McAlister T, Fisher BR, Goering PL. Mercury, cadmium, and arsenite enhance heat shock protein synthesis in chick embryos prior to embryotoxicity. Birth Defects Res Part B Dev Reprod Toxicol. 2003 Dec;68(6):456-64.

57. Noda M, Wataha JC, Lewis JB, Lockwood PE, Komatsu H, Sano H. Hg2+ and $\mathrm{Ni2}+$ alter induction of heat shock protein-72 in THP-1 human monocytes. J Biomed Mater Res. 2003 Oct 1;67A(1):240-5.

58. Cedrola S, Guzzi G, Ferrari D, Gritti A, Vescovi AL, Pendergrass JC, La Porta CA. Inorganic mercury changes the fate of murine CNS stem cells. FASEB J. 2003 May;17(8):869-71. Epub 2003 Mar 28.

59. Goering PL, Fisher BR, Noren BT, Papaconstantinou A, Rojko JL, Marler RJ. Mercury induces regional and cell-specific stress protein expression in rat kidney. Toxicol Sci. 2000 Feb;53(2):447-57.

60. Liu J, Lei D, Waalkes MP, Beliles RP, Morgan DL. Genomic analysis of the rat lung following elemental mercury vapor exposure. Toxicol Sci. 2003 Jul;74(1):174-81. Epub 2003 May 02.

61. Dieguez-Acuna FJ, Ellis ME, Kushleika J, Woods JS. Mercuric ion attenuates nuclear factor-kappaB activation and DNA binding in normal rat kidney epithelial cells: implications for mercury-induced nephrotoxicity. Toxicol Appl Pharmacol. 2001 Jun 15;173(3):176-87.

62. Kim SH, Sharma RP. Cytotoxicity of inorganic mercury in murine $T$ and $B$ lymphoma cell lines: involvement of reactive oxygen species, $\mathrm{Ca}(2+)$ homeostasis, and cytokine gene expression. Toxicol In Vitro. 2003 Aug;17(4):385-95.

63. Goering PL, Morgan DL, Ali SF. Effects of mercury vapor inhalation on reactive oxygen species and antioxidant enzymes in rat brain and kidney are minimal. $\mathrm{J}$ Appl Toxicol. 2002 May-Jun;22(3):167-72. 
64. Ercal N, Gurer-Orhan H, Aykin-Burns N. Toxic metals and oxidative stress part I: mechanisms involved in metal-induced oxidative damage. Curr Top Med Chem. 2001 Dec;1(6):529-39.

65. Kim SH, Sharma RP. Mercury-induced apoptosis and necrosis in murine macrophages: role of calcium-induced reactive oxygen species and p38 mitogenactivated protein kinase signaling. Toxicol Appl Pharmacol. 2004 Apr 1;196(1):4757.

66. Tan XX, Tang C, Castoldi AF, Manzo L, Costa LG. Effects of inorganic and organic mercury on intracellular calcium levels in rat $\mathrm{T}$ lymphocytes. J Toxicol Environ Health. 1993 Feb;38(2):159-70.

67. Langard S. One hundred years of chromium and cancer: a review of epidemiological evidence and selected case reports. Am J Ind Med. 1990;17(2):189-215.

68. O'Brien TJ, Ceryak S, Patierno SR. Complexities of chromium carcinogenesis: role of cellular response, repair and recovery mechanisms. Mutat Res. 2003 Dec $10 ; 533(1-2): 3-36$

69. Costa M. Carcinogenic metals. Sci Prog. 1998;81 ( Pt 4):329-39.

70. Bagchi D, Stohs SJ, Downs BW, Bagchi M, Preuss HG. Cytotoxicity and oxidative mechanisms of different forms of chromium. Toxicology. 2002 Oct 30;180(1):5-22.

71. Morris BW, Blumsohn A, Mac Neil S, Gray TA. The trace element chromium--a role in glucose homeostasis. Am J Clin Nutr. 1992 May;55(5):989-91.

72. Cefalu WT, Wang ZQ, Zhang XH, Baldor LC, Russell JC. Oral chromium picolinate improves carbohydrate and lipid metabolism and enhances skeletal muscle Glut-4 translocation in obese, hyperinsulinemic (JCR-LA corpulent) rats. J Nutr. 2002 Jun;132(6):1107-14. 
73. Alexander J, Aaseth J. Uptake of chromate in human red blood cells and isolated rat liver cells: the role of the anion carrier. Analyst. 1995 Mar;120(3):931-3.

74. Shi X, Chiu A, Chen CT, Halliwell B, Castranova V, Vallyathan V. Reduction of chromium(VI) and its relationship to carcinogenesis. J Toxicol Environ Health B Crit Rev. 1999 Jan-Mar;2(1):87-104.

75. Shi XL, Dalal NS. Chromium (V) and hydroxyl radical formation during the glutathione reductase-catalyzed reduction of chromium (VI). Biochem Biophys Res Commun. 1989 Aug 30;163(1):627-34.

76. Shi XG, Dalal NS. On the hydroxyl radical formation in the reaction between hydrogen peroxide and biologically generated chromium(V) species. Arch Biochem Biophys. 1990 Mar;277(2):342-50.

77. Xu J, Wise JP, Patierno SR. DNA damage induced by carcinogenic lead chromate particles in cultured mammalian cells. Mutat Res. 1992 Aug;280(2):129-36.

78. IARC Monograph on the Evaluation of Carcinogenic Risk to Humans, Chromium, Nickel, and Welding, Lyon, France, 1990. vol. 49, pp. 1-677.

79. EPA Health Effects Assessment for Hexavalent Chromium, Office of Emergency and Remedial Response, US Environmental Protection Agency, Cincinnaiti, OH, 1984.

80. Kasprzak KS, Sunderman FW Jr, Salnikow K. Nickel carcinogenesis. Mutat Res. 2003 Dec 10;533(1-2):67-97.

81. Cangul H, Broday L, Salnikow K, Sutherland J, Peng W, Zhang Q, Poltaratsky V, Yee $\mathrm{H}$, Zoroddu MA, Costa M. Molecular mechanisms of nickel carcinogenesis. Toxicol Lett. 2002 Feb 28;127(1-3):69-75.

82. Chen CY, Wang YF, Huang WR, Huang YT. Nickel induces oxidative stress and genotoxicity in human lymphocytes. Toxicol Appl Pharmacol. 2003 Jun 15;189(3):153-9. 
83. Denkhaus E, Salnikow K. Nickel essentiality, toxicity, and carcinogenicity. Crit Rev Oncol Hematol. 2002 Apr;42(1):35-56.

84. Cohen MD, McManus TP, Yang Z, Qu Q, Schlesinger RB, Zelikoff JT. Vanadium affects macrophage interferon-gamma-binding and -inducible responses. Toxicol Appl Pharmacol. 1996 May;138(1):110-20.

85. Pierce LM, Alessandrini F, Godleski JJ, Paulauskis JD. Vanadium-induced chemokine mRNA expression and pulmonary inflammation. Toxicol Appl Pharmacol. 1996 May;138(1):1-11.

86. Grabowski GM, Paulauskis JD, Godleski JJ. Mediating phosphorylation events in the vanadium-induced respiratory burst of alveolar macrophages. Toxicol Appl Pharmacol. 1999 May 1;156(3):170-8.

87. Carter JD, Ghio AJ, Samet JM, Devlin RB. Cytokine production by human airway epithelial cells after exposure to an air pollution particle is metal-dependent. Toxicol Appl Pharmacol. 1997 Oct;146(2):180-8.

88. Ye J, Ding M, Zhang X, Rojanasakul Y, Nedospasov S, Vallyathan V, Castranova $\mathrm{V}$, Shi $\mathrm{X}$. Induction of TNFalpha in macrophages by vanadate is dependent on activation of transcription factor NF-kappaB and free radical reactions. Mol Cell Biochem. 1999 Aug;198(1-2):193-200.

89. Huang C, Ding M, Li J, Leonard SS, Rojanasakul Y, Castranova V, Vallyathan V, Ju G, Shi X. Vanadium-induced nuclear factor of activated $\mathrm{T}$ cells activation through hydrogen peroxide. J Biol Chem. 2001 Jun 22;276(25):22397-403. Epub 2001 Apr 05.

90. Huang C, Zhang Z, Ding M, Li J, Ye J, Leonard SS, Shen HM, Butterworth L, Lu Y, Costa M, Rojanasakul Y, Castranova V, Vallyathan V, Shi X. Vanadate induces p53 transactivation through hydrogen peroxide and causes apoptosis. J Biol Chem. 2000 Oct 20;275(42):32516-22. 
91. Chen F, Shi X. Intracellular signal transduction of cells in response to carcinogenic metals. Crit Rev Oncol Hematol. 2002 Apr;42(1):105-21.

92. Elbetieha $\mathrm{A}$, Bataineh $\mathrm{H}$, Darmani $\mathrm{H}$, Al-Hamood $\mathrm{MH}$. Effects of long-term exposure to manganese chloride on fertility of male and female mice. Toxicol Lett. 2001 Mar 8;119(3):193-201.

93. HaMai D, Bondy SC. Oxidative basis of manganese neurotoxicity. Ann N Y Acad Sci. 2004 Mar;1012:129-41.

94. Dobson AW, Erikson KM, Aschner M. Manganese neurotoxicity. Ann N Y Acad Sci. 2004 Mar;1012:115-28.

95. Daniels AJ, Abarca J. Effect of intranigral Mn2+ on striatal and nigral synthesis and levels of dopamine and cofactor. Neurotoxicol Teratol. 1991 Sep-Oct;13(5):483-7.

96. Simonian NA, Coyle JT. Oxidative stress in neurodegenerative diseases. Annu Rev Pharmacol Toxicol. 1996;36:83-106.

97. Parenti M, Rusconi L, Cappabianca V, Parati EA, Groppetti A. Role of dopamine in manganese neurotoxicity. Brain Res. 1988 Nov 15;473(2):236-40.

98. Ali SF, Duhart HM, Newport GD, Lipe GW, Slikker W Jr. Manganese-induced reactive oxygen species: comparison between $M n+2$ and $M n+3$. Neurodegeneration. 1995 Sep;4(3):329-34.

99. Roth JA, Feng L, Walowitz J, Browne RW. Manganese-induced rat pheochromocytoma (PC12) cell death is independent of caspase activation. J Neurosci Res. 2000 Jul 15;61(2):162-71.

100. Schmidt KN, Traenckner EB, Meier B, Baeuerle PA. Induction of oxidative stress by okadaic acid is required for activation of transcription factor NF-kappa B. J Biol Chem. 1995 Nov 10;270(45):27136-42. 
101. Ramesh GT, Ghosh D, Gunasekar PG. Activation of early signaling transcription factor, NF-kappaB following low-level manganese exposure. Toxicol Lett. 2002 Dec 15;136(2):151-8.

102. Sundin DS. National occupational exposure survey data base, 1981-1983. In NIOSH Criteria for Recommended Standard for Welding, Brazing, and Thermal Cutting (US Department of Health and Human Services, Public Health Service, Centers for Disease Control and National Institute for Occupational Safety and Health, Eds.), Publication No. 88-10.

103. Antonini JM: Health effects of welding. Crit Rev Toxicol 2003;33:61-103.

104. Bureau of Labor Statistics. Welders, cutters, solderers, and brazers. In: Occupational Employment Statistics and Wages: 2002. Available at: http://stats.bls.gov/oes/2002/oes514121.htm.

105. Howden DG, Desmeules MJA, Saracci R, Sprince NL, Herber PI. Respiratory hazards of welding: occupational exposure characterization. Am Rev Respir Dis 1988;138:1047-1048.

106. Stern RM. Process-dependent risk of delayed health effects for welders. Environ Health Perspect 1981;41:235-253.

107. Beach JR, Dennis JH, Avery AJ, Bromly CL, Ward RJ, Walters EH, Stenton SC, Hendrick DJ. An epidemiologic investigation of asthma in welders. Am J Respir Crit Care Med 1996;154(5):1394-1400.

108. Wang ZP, Larsson K, Malmberg P, Sjogren B, Hallberg BO, Wrangskog K. Asthma, lung function, and bronchial responsiveness in welders. Am J Ind Med 1994;26(6):741-754.

109. Lucchini R, Apostoli P, Perrone C, Placidi D, Albini E, Migliorati P, Mergler D, Sassine MP, Palmi S, Alessio L. Long term exposure to low levels of manganese 
oxides and neurofunctional changes in ferroalloy workers. NeuroToxicol 1999;20:287-298.

110. Sobaszek A, Boulenguez C, Frimat P, Robin H, Haguenoer JM, Edme JL. Acute respiratory effects of exposure to stainless steel and mild steel welding fumes. $J$ Occup Environ Med 2000;42(9):923-931.

111. De Flora S, Bagnasco M, Serra D, Zanacchi P. Genotoxicity of chromium compounds. A review. Mutat Res 1990;238(2):99-172.

112. Costa M, Zhitkovich A, Taioli E, Toniolo P. Preliminary report on a simple new assay for DNA-protein cross-links as a biomarker of exposures experienced by welders. J Toxicol Environ Health 1993a;40(2-3):217-222.

113. Costa M, Zhitkovich A, Toniolo P. DNA-protein cross-links in welders: molecular implications. Cancer Res 1993b;53(3):460-463.

114. Connett PH, Wetterhahn KE. Metabolism of the carcinogenic chromate by cellular constituents. Struct Bonding 1983;54:93-124.

115. Costa M. Toxicity and carcinogenicity of $\operatorname{Cr}(\mathrm{VI})$ in animal models and humans. Crit Rev Toxicol 1997;27:431-442.

116. Sferlazza SJ, Beckett WS. The respiratory health of welders. Am Rev Respir Dis 1991;143:1134-1148.

117. Lindquist S, Craig EA. The heat-shock proteins. Annu Rev Genet. 1988;22:63177.

118. Fink AL. Chaperone-mediated protein folding. Physiol Rev. 1999 Apr;79(2):42549.

119. Snoeckx LH, Cornelussen RN, Van Nieuwenhoven FA, Reneman RS, Van Der Vusse GJ. Heat shock proteins and cardiovascular pathophysiology. Physiol Rev. 2001 Oct;81(4):1461-97. 
120. Georgopoulos C, Welch WJ. Role of the major heat shock proteins as molecular chaperones. Annu Rev Cell Biol. 1993;9:601-34.

121. Ciocca DR, Oesterreich S, Chamness GC, McGuire WL, Fuqua SA. Biological and clinical implications of heat shock protein 27,000 (Hsp27): a review. J Natl Cancer Inst. 1993 Oct 6;85(19):1558-70.

122. Kregel KC. Heat shock proteins: modifying factors in physiological stress responses and acquired thermotolerance. J Appl Physiol. 2002 May;92(5):217786.

123. Del Razo LM, Quintanilla-Vega B, Brambila-Colombres E, Calderon-Aranda ES, Manno M, Albores A. Stress proteins induced by arsenic. Toxicol Appl Pharmacol. 2001 Dec 1;177(2):132-48.

124. Hendrick JP, Hartl FU. Molecular chaperone functions of heat-shock proteins. Annu Rev Biochem. 1993;62:349-84.

125. Wu BJ, Kingston RE, Morimoto RI. Human HSP70 promoter contains at least two distinct regulatory domains. Proc Natl Acad Sci U S A. 1986 Feb;83(3):629-33.

126. Freeman BC, Myers MP, Schumacher R, Morimoto RI. Identification of a regulatory motif in Hsp70 that affects ATPase activity, substrate binding and interaction with HDJ-1. EMBO J. 1995 May 15;14(10):2281-92.

127. Green M, Schuetz TJ, Sullivan EK, Kingston RE. A heat shock-responsive domain of human HSF1 that regulates transcription activation domain function. Mol Cell Biol. 1995 Jun;15(6):3354-62.

128. Baler R, Dahl G, Voellmy R. Activation of human heat shock genes is accompanied by oligomerization, modification, and rapid translocation of heat shock transcription factor HSF1. Mol Cell Biol. 1993 Apr;13(4):2486-96.

129. Goodson ML, Sarge KD. Heat-inducible DNA binding of purified heat shock transcription factor 1. J Biol Chem. 1995 Feb 10;270(6):2447-50. 
130. Hung JJ, Cheng TJ, Chang MD, Chen KD, Huang HL, Lai YK. Involvement of heat shock elements and basal transcription elements in the differential induction of the $70-\mathrm{kDa}$ heat shock protein and its cognate by cadmium chloride in $9 \mathrm{~L}$ rat brain tumor cells. J Cell Biochem. 1998 Oct 1;71(1):21-35.

131. Knauf U, Newton EM, Kyriakis J, Kingston RE. Repression of human heat shock factor 1 activity at control temperature by phosphorylation. Genes Dev. 1996 Nov 1;10(21):2782-93.

132. Mivechi NF, Koong AC, Giaccia AJ, Hahn GM. Analysis of HSF-1 phosphorylation in A549 cells treated with a variety of stresses. Int $\mathrm{J}$ Hyperthermia. 1994 May-Jun;10(3):371-9.

133. Santoro MG. Heat shock factors and the control of the stress response. Biochem Pharmacol. 2000 Jan 1;59(1):55-63.

134. Walsh RC, Koukoulas I, Garnham A, Moseley PL, Hargreaves M, Febbraio MA. Exercise increases serum Hsp72 in humans. Cell Stress Chaperones. 2001 Oct;6(4):386-93.

135. Nishizawa J, Nakai A, Matsuda K, Komeda M, Ban T, Nagata K. Reactive oxygen species play an important role in the activation of heat shock factor 1 in ischemic-reperfused heart. Circulation. 1999 Feb 23;99(7):934-41.

136. Harris GK, Shi X. Signaling by carcinogenic metals and metal-induced reactive oxygen species. Mutat Res. 2003 Dec 10;533(1-2):183-200.

137. Park HS, Lee JS, Huh SH, Seo JS, Choi EJ. Hsp72 functions as a natural inhibitory protein of c-Jun N-terminal kinase. EMBO J. 2001 Feb 1;20(3):446-56.

138. Park HS, Cho SG, Kim CK, Hwang HS, Noh KT, Kim MS, Huh SH, Kim MJ, Ryoo K, Kim EK, Kang WJ, Lee JS, Seo JS, Ko YG, Kim S, Choi EJ. Heat shock protein hsp72 is a negative regulator of apoptosis signal-regulating kinase 1. Mol Cell Biol. 2002 Nov;22(22):7721-30. 
139. Gabai VL, Meriin AB, Yaglom JA, Wei JY, Mosser DD, Sherman MY. Suppression of stress kinase JNK is involved in HSP72-mediated protection of myogenic cells from transient energy deprivation. HSP72 alleviates the stewssinduced inhibition of JNK dephosphorylation. J Biol Chem. 2000 Dec 1;275(48):38088-94.

140. Gabai VL, Mabuchi K, Mosser DD, Sherman MY. Hsp72 and stress kinase c-jun $\mathrm{N}$-terminal kinase regulate the bid-dependent pathway in tumor necrosis factorinduced apoptosis. Mol Cell Biol. 2002 May;22(10):3415-24.

141. Beere HM, Wolf BB, Cain K, Mosser DD, Mahboubi A, Kuwana T, Tailor P, Morimoto RI, Cohen GM, Green DR. Heat-shock protein 70 inhibits apoptosis by preventing recruitment of procaspase-9 to the Apaf-1 apoptosome. Nat Cell Biol. 2000 Aug;2(8):469-75.

142. Volloch V, Gabai VL, Rits S, Force T, Sherman MY. HSP72 can protect cells from heat-induced apoptosis by accelerating the inactivation of stress kinase JNK. Cell Stress Chaperones. 2000 Apr;5(2):139-47.

143. Fuller KJ, Issels RD, Slosman DO, Guillet JG, Soussi T, Polla BS. Cancer and the heat shock response. Eur J Cancer. 1994;30A(12):1884-91.

144. Volloch VZ, Sherman MY. Oncogenic potential of Hsp72. Oncogene. 1999 Jun 17;18(24):3648-51.

145. Zylicz M, King FW, Wawrzynow A. Hsp70 interactions with the p53 tumour suppressor protein. EMBO J. 2001 Sep 3;20(17):4634-8.

146. Jolly C, Morimoto RI. Role of the heat shock response and molecular chaperones in oncogenesis and cell death. J Natl Cancer Inst. 2000 Oct 4;92(19):1564-72.

147. Freeman BC, Morimoto RI. The human cytosolic molecular chaperones hsp90, hsp70 (hsc70) and hdj-1 have distinct roles in recognition of a non-native protein and protein refolding. EMBO J. 1996 Jun 17;15(12):2969-79. 
148. Nadeau D, Corneau S, Plante I, Morrow G, Tanguay RM. Evaluation for Hsp70 as a biomarker of effect of pollutants on the earthworm Lumbricus terrestris. Cell Stress Chaperones 6:153-63, 2001.

149. Lewis S, Donkin ME, Depledge MH. Hsp70 expression in Enteromorpha intestinalis (Chlorophyta) exposed to environmental stressors. Aquat Toxicol $51: 277-91,2001$.

150. Sanders BM, Martin LS. Stress proteins as biomarkers of contaminant exposure in archived environmental samples. Sci Total Environ 139-140:459-70, 1993.

151. Delmas F, Trocheri V, Miro C, Villaescusa I, Murat JC. Expression of stress proteins in cultured human cells as a sensitive indicator of metal toxicity. Fresenius J Anal Chem. 354: 615-619, 1996.

152. Child DF, Williams CP, Jones RP, Hudson PR, Jones M, Smith CJ. Heat shock protein studies in type 1 and type 2 diabetes and human islet cell culture. Diabet Med. 1995 Jul;12(7):595-9.

153. Hightower LE, Guidon PT Jr. Selective release from cultured mammalian cells of heat-shock (stress) proteins that resemble glia-axon transfer proteins. J Cell Physiol. 1989 Feb;138(2):257-66. 


\section{MATERIALS AND METHODS I}

(FOR CHAPTERS I-IV)

\section{Reagents}

Arsenic $\left(\mathrm{AsCl}_{3}\right)$, cadmium $\left(\mathrm{CdCl}_{2}\right)$, mercury $\left(\mathrm{HgCl}_{2}\right)$, chromium $\left(\mathrm{Na}_{2} \mathrm{Cr}_{2} \mathrm{O}_{7}\right)$, nickel $\left(\mathrm{NiCl}_{2}\right)$, vanadium $\left(\mathrm{NaVO}_{3}\right)$, and manganese $\left(\mathrm{MnSO}_{4}\right)$ were purchased from Aldrich (Milwaukee, $\mathrm{WI}$ ), and catalase, superoxide dismutase (SOD), sodium formate (SF), Nacetyl-cysteine (NAC), and actinomycin D were obtained from Sigma (St Louis, MO). DMPO (5,5-dimethyl-1-pyrroline N-oxide) was purchased from Alexis Biochemicals (San Diego, CA). Hoechst 33342, $\mathrm{H}_{2}$ DCFDA and dihydroethidium were purchased from Molecular Probes (Eugene, OR).

\section{Cell Culture}

BEAS-2B cells (ATCC, Rockville, MD) were grown to $95 \%$ confluence at $37^{\circ} \mathrm{C}$ in a $5 \% \mathrm{CO}_{2}$ atmosphere using Dulbecco's modified Eagles' growth medium (DMEM) supplemented with $5 \%$ FBS and penicillin (100 units/ml)-streptomycin (100 $\mu \mathrm{g} / \mathrm{ml})$. Medium was changed every 2-3 days and cells were subcultured using trypsin-EDTA at confluence. Exposure of BEAS-2B cells to metals in culture was performed in the presence of $0.1 \%$ serum. After metal exposure, the cells were placed in fresh medium containing $5 \%$ serum for various periods $(0-96 \mathrm{hr})$.

\section{Cytotoxicity Assay}

The effects of metal treatments on the cytotoxicity of cells were determined by the MTT (3-[4, 5-dimethylthiazol-2-yl]-2, 5-diphenyl tetrazolium bromide) assay (1), according to the manufacturer's protocol (Roche, Indianapolis, IN). 
Apoptosis Assay

BEAS-2B $\left(2 \times 10^{5} /\right.$ well $)$ cells were seeded in the wells of 12 -well plate for $24 \mathrm{hr}$. The cells were exposed to metals for $4 \mathrm{hr}$ and then stained with the Hoechst dye 33342 (Molecular Probes, Eugene, OR) at $1 \mu \mathrm{g} / \mathrm{ml}$ for $15 \mathrm{~min}$. Cells were observed by UV fluorescence microscopy with appropriate filter block set. Non-exposed cells served as negative control. At least 100 cells in five random areas per well were analyzed for apoptosis based on the presence of nucleic acid condensation. Images were acquired using a digital camera (Pixera Pro 150ES), Viewfinder 3.0 and Studio 3.0 program (Pixera Corporation, CA).

\section{ESR Measurements}

Electron spin resonance (ESR) was used to detect short-lived free radical intermediates. Short-lived free radical intermediates were spin trapped with DMPO present in the reaction medium. ESR measurements were carried out, using a Bruker EMX ESR spectrometer (Bruker Instruments Inc., Billerica, MA) and a flat-cell assembly (2, 3). Hyperfine couplings were measured (0.1 Gauss) directly from magnetic field separation, using $\mathrm{K}_{3} \mathrm{CrO}_{8}$ and 1,1-diphenyl-2-picrylhydrazyl as standards. All the measurements were carried out at room temperature at $50 \mathrm{~mW}$ microwave power, $2 \mathrm{G}$ modulation amplitude and a magnetic field of $3490 \pm 50 \mathrm{G}$. Three scans were integrated for all the samples, and the scaling and analysis of the spectra were made using an Acquist program (Bruker Instruments Inc., Billerica, MA).

BEAS-2B cells $\left(1 \times 10^{6}\right)$ were mixed with $200 \mathrm{mM}$ DMPO, and metals $(100 \mu \mathrm{M})$ in a final volume of $1 \mathrm{ml}$. Reactants were incubated for $10 \mathrm{~min}$ at $37^{\circ} \mathrm{C}$ and transferred to a flat cell for ESR measurements.

Western Blot Analysis 
Cells were washed three times with PBS and harvested by scraping. The cells were sedimented by centrifugation. The supernatant was aspirated, and cells resuspended in lysis buffer at $\mathrm{pH} 7.5$, containing ( $20 \mathrm{mM}$ Tris- $\mathrm{HCl}, 150 \mathrm{mM} \mathrm{NaCl}, 1 \mathrm{mM}$ $\mathrm{Na}_{2}$ EDTA, $1 \mathrm{mM}$ EGTA, $1 \%$ Triton, $2.5 \mathrm{mM}$ sodium pyrophosphate, $1 \mathrm{mM} \beta-$ glycerophosphate, $1 \mathrm{mM} \mathrm{Na} \mathrm{VO}_{4}, 1 \mu \mathrm{g} / \mathrm{ml}$ leupeptin) and protease inhibitors (Roche, Indianapolis, IN). After a brief sonication, lysed cells were centrifuged at $12,000 \mathrm{~g}$ for 10 min at $4{ }^{\circ} \mathrm{C}$, and supernatants were transferred to new tubes and stored at $-70^{\circ} \mathrm{C}$. The concentration of protein in the samples was determined by the DC protein assay (BioRad, Hercules, CA). Hsp70 protein was separated from $30 \mu \mathrm{g}$ of total protein aliquots of samples using $10 \%$ SDS-PAGE and then transferred onto $0.2 \mu \mathrm{m}$ nitrocellulose membranes (Bio-Rad, Hercules, CA). The membrane blots were incubated with a blocking buffer (non-fat milk $5 \%(\mathrm{w} / \mathrm{v})$ in Tris buffered saline and $0.1 \%$ Tween-20) for 1 $\mathrm{hr}$, and then incubated with AP conjugated mouse monoclonal antibodies specific for Hsp70 (StressGen, Victoria, BC, Canada) in the blocking buffer for $1 \mathrm{hr}$ at room temperature. Antibody was diluted 1:10,000 in the blocking buffer. After three washes in buffer, the blots were incubated with color developing reagent (Bio-Rad, Hercules, $\mathrm{CA}$ ), according to the manufacturer's protocol. To test the effect of antioxidants on metal-induced Hsp70 protein expression, BEAS-2B cells were exposed to various concentrations of metals with or without antioxidants for 3 or $6 \mathrm{hr}$ and harvested for Western blotting as described above. For actinomycin D experiments, cells were exposed to actinomycin D solution with $0.5 \mu \mathrm{g} / \mathrm{ml}$ of final concentration in cell culture media 30 min prior to a $3 \mathrm{hr}$ treatment with metals followed by a $12 \mathrm{hr}$ recovery period.

\section{Hsp70 ELISA}

An enzyme-linked immunosorbent assay (StressGen, Victoria, BC, Canada) was used to determine the relative expression of Hsp70 protein in cell lysates. Cell lysates 
were prepared according to manufacturer's protocol, using extraction buffer containing protease inhibitors. One hundred microliters of total protein samples $(0.025 \mu \mathrm{g}$ of total proteins $/ \mu \mathrm{l}$ ) were added to the microassay plate. After the completion of the color developing reaction, the absorbance of samples were measured at $450 \mathrm{~nm}$ using a microplate spectrophotometer (Molecular Devices, Sunnyvale, CA). The Hsp70 concentrations were expressed as $\mathrm{ng} / \mathrm{mg}$ protein interpolated from the constructed standard curve.

Isolation of Total RNA and RT-PCR

To determine the expression of Hsp70A, B, and C, $500 \mathrm{ng}$ of total RNA was reverse transcribed with random hexamer primers. The samples were reverse transcribed for $15 \mathrm{~min}$ at $42^{\circ} \mathrm{C}$, followed by a 5 min denaturation step at $99^{\circ} \mathrm{C}$, using a DNA thermal cycler (Hybaid, Middlesex, UK). The resulting cDNA was amplified in 100 $\mu l$ reaction by PCR (30 cycles) with commercially available oligonucleotides specific for Hsp70A, B, or C (StressGen, Victoria, BC, Canada). Hsp70 primers specific for Hsp A, $B$, or C were (forward and reverse, respectively): 5'TGTTCCGTTTCCAGCCCCCAA3' and $\quad$ 5'GGGCTTGTCTCCGTCGTTGAT3' (STM-506) for 5'CTCCAGCATCCGACAAGAAGC3' and 5'ACGGTGTTGTGGGGGTTCAGG3' (STM507) for 70B; and 5'TTGAGGAGGTGGATAGGGGC3' and 5'AGCCTTTGTAGTGTTTTCGCC3' (STM-508) for 70C. Primers for the determination of glyceraldehyde 3-phosphate dehydrogenase (G3PDH) housekeeping gene expression were purchased commercially (Clontech, Palo Alto, CA). PCR cycles consisted of 2 min initial step at $95^{\circ} \mathrm{C}$ followed by $30 \mathrm{sec}$ at $95^{\circ} \mathrm{C}, 30 \mathrm{sec}$ at $58^{\circ} \mathrm{C}$, and $30 \mathrm{sec}$ at $72^{\circ} \mathrm{C}$ with a final elongation step for $15 \mathrm{~min}$ at $72^{\circ} \mathrm{C}$. The final PCR products were electrophoresed on $2 \%$ agarose gels containing ethidium bromide along with DNA markers. Optical densities of the samples were obtained by ethidium bromide 
fluorescent imaging into an ImageQuant 5.1 (Molecular Dynamics, Piscataway, NJ), using a Stratagene Eagle Eye II (La Jolla, CA). The amount of Hsp70 mRNA expressed was calculated by the ratio of the Hsp70 reaction product to that of the housekeeping gene, G3PDH (4).

\section{Lipid Peroxidation Measurements}

A lipid peroxidation by-product, 8-isoprostane, was measured in the supernatant as a marker of oxidative injury to cells exposed to arsenic. The isoprostanes are produced by non-enzymatic random oxidation of tissue phospholipids by oxygen radicals. The method used for isoprostane assay is a competitive enzyme-linked assay for determining 8-isoprostane in biological samples, using an 8-isoprostaneacetylcholineserase (AChE) conjugate for a limited number of 8-isoprostane-specific rabbit antiserum sites. The ELISA method (Cayman, Ann Arbor, MI) was used, according to manufacturer's protocol, to determine time and concentration-dependent lipid peroxidation induced by metals. After exposure to metals, the media was analyzed for 8-isoprostane in duplicate aliquots of $50 \mu$ of samples. Samples were exposed for $18 \mathrm{hr}$ in plates coated with antibody and then treated with substrate for one hr for color development. Absorbance of color developed was read at $410 \mathrm{~nm}$, using a microplate spectrophotometer with standards and controls treated similarly. The concentration of 8isoprostane produced was calculated from a standard curve.

Intracellular $\mathrm{H}_{2} \mathrm{O}_{2}$ and ${ }^{\circ} \mathrm{O}_{2}^{-}$Detection by Confocal Microscopy

Intracellular ROS production was tested using $\mathrm{H}_{2}$ DCFDA and dihydroethidium for $\mathrm{H}_{2} \mathrm{O}_{2}$ and $\mathrm{O}_{2}^{-}$, respectively $(5,6)$. BEAS-2B cells $\left(1 \times 10^{5} /\right.$ well $)$ were seeded onto a glass coverslip in the wells of 24-well plate for $24 \mathrm{hr}$. The cells were exposed to metals for $1 \mathrm{hr}$ in the presence of $\mathrm{H}_{2}$ DCFDA $(25 \mu \mathrm{M})$ or dihydroethidium $(10 \mu \mathrm{M})$. The cells 
were then washed with PBS, fixed with $10 \%$ buffered formalin for $10 \mathrm{~min}$, and mounted on glass slides using Prolong Antifade (Molecular Probes, Eugene, OR). Slides were observed using a Zeiss LSM 510 (Carl Zeiss, Inc., Thornwood, NY) laser scanning confocal microscope.

Statistical Analysis

Statistical analysis of data was undertaken, using the Sigma Stat (Jandel Scientific Software, San Rafael, CA) statistical program. Data presented are the means \pm SE of values compared and analyzed using a one-way ANOVA, and values of $p<0.05$ were considered statistically significant. 


\section{MATERIALS AND METHODS II}

(FOR CHAPTER V)

\section{Study Population}

The study population consisted of 197 healthy male welders with one to 33 years of exposure history in a large ship building industry in Ulsan, South Korea. All welders were employed full time and involved in the use of a gas metal arc welding process with carbon dioxide as shielding gas. All the welders in the study population did not work in a single specific job or work site on a regular basis, but were involved in various welding related processes including welding, cutting, fitting, and work on the docks of the shipyard. They worked in various conditions, such as semi-enclosed or open areas, and were exposed to different levels of welding fumes in all occupations. Most of the workers used single use disposable half mask respirators for particulates. As controls, 150 white-collar office workers in the same industrial complex matched for age and cigarette smoking were used.

Basic demographic data on 150 controls including height, weight, years smoked and cigarette smoked per day are presented in Table I. Demographic information, with population characteristics on height, weight, age, years smoked, cigarettes smoked per day and welding exposure are presented for welders in Table II with mean values for manganese and lead levels in blood.

\section{Welding Fume Exposure Assessment}

Ambient air samples were collected with personal air samplers (Gil-Air Sampler, Gilian Instrument Corp. West Caldwell, NJ) on mixed cellulose ester membrane filters (Millipore Corp., Billerica, MA) with a pore size of $0.8 \mu \mathrm{m}$ and $37 \mathrm{~mm}$ diameter. Sampling was done for six hours at a flow rate of $1-2.5 \mathrm{l} / \mathrm{min}$. Measurements of ambient 
air samples taken outside the welding helmet ranged from 1.8 to $13.2 \mathrm{mg} / \mathrm{m}^{3}$ for welding fume particulate load. Samples of welding fume particulates collected on cellulose filters were analyzed by flame absorption spectrometry using a Varian 300 plus spectrophotometer (Varian Techtron Pty, Victoria, Australia) according to NIOSH 7300 analytical methods for $\mathrm{Mn}, \mathrm{Fe}, \mathrm{Zn}, \mathrm{Pb}, \mathrm{Cr}, \mathrm{Cu}$, and $\mathrm{Ni}$. The data obtained for ambient air concentrations of these metals and welding fume in the welding work areas are presented in Table III. Biological exposures to $\mathrm{Mn}$ and $\mathrm{Pb}$ in welders were assessed in whole blood samples collected after work shift. $\mathrm{Mn}$ and $\mathrm{Pb}$ in blood samples were measured by atomic absorption spectroscopy using a Varian Spectra AA Spectrophotometer (Varian Techtron Pty, Victoria, Australia). The data obtained for 197 welders used in this study are presented in Table II with other demographic data. From all the welders and controls, peripheral venous blood was collected without any anticoagulants in plain tubes and kept at room temperature for $10 \mathrm{~min}$. The serum was then separated by centrifugation at $1500 \times \mathrm{g}$ for $10 \mathrm{~min}$ and stored in plastic tubes at $80^{\circ} \mathrm{C}$ until separated into aliquots and assayed. The study protocol was approved by the Bioethics Committee of the University of Ulsan School of Medicine, Ulsan, South Korea. An informed consent was obtained from all the study participants.

At the completion of analytical studies of serum samples on a blind basis, the data were segregated and analyzed in four groups consisting of 150 controls (75 smokers and 75 nonsmokers), 142 welders with 1-10 years of welding exposure (103 smokers and 39 nonsmokers), 27 welders (17 smokers and 10 nonsmokers) with 11-20 years of welding exposure, and 28 welders (5 smokers and 23 nonsmokers) with 20 or more years of welding exposure. Detailed demographic data on welders based on exposure duration with mean values for manganese and lead levels in the blood are presented in Table IV. 
Total Protein and Albumin

Total serum protein and albumin levels are valuable markers for monitoring several disease conditions and changes caused by oxidative stress. Amino acid side chains and albumin are susceptible to oxidative damage. A Sigma Diagnostics (St Louis, MO) method was used to determine the concentration of total proteins in the serum samples. This method is based on the biuret reaction. The copper ions in the alkaline biuret reagent react with peptide bonds of serum proteins to form a purple color which was measured at an absorbance of $540 \mathrm{~nm}$. Total serum albumin was determined by a Sigma Diagnostics (St Louis, MO) method based on the reaction of albumin with bromocresol green (BCG). The reaction product of serum albumin in both welders and controls was measured using an autoanalyzer at an absorbance of $600 \mathrm{~nm}$ (Cobas Mira Roche, Montclair, NJ). The concentrations of total protein and albumin in the serum samples were calculated from standards constructed with known amounts of protein and albumin.

Total Antioxidant Status (TAS)

Total antioxidant activity was measured by monitoring the radical cation formation from 2,2'-azino-di[3-ethylbenzthiazoline sulphonate] (ABTS) incubated with a peroxidase (metmyoglobin) and $\mathrm{H}_{2} \mathrm{O}_{2}$ to produce a radical cation with a stable blue color, which was measured at $600 \mathrm{~nm}(7)$. Antioxidants present in the serum samples cause a suppression of this color which is proportional to total antioxidant concentration. The colorimetric method was programmed into a Cobas Mira Autoanalyzer using a Randox kit (Randox Laboratories, San Francisco, CA). Serum samples from welders and controls were analyzed for total antioxidant status and results, expressed in $\mathrm{mmol} / \mathrm{L}$, were calculated from a standard curve. 


\section{Aconitase}

Aconitase activity is considered a sensitive and specific indicator of oxidative injury and disease progression. Aconitase activity was measured in serum samples of welders and controls using a Bioxytech aconitase-340 assay kit, according to manufacturer's protocol (OxisResearch, Portland, OR). The assay is based on the isomerization of citrate to isocitrate and the measurement of $\mathrm{NADPH}$ formed from $\mathrm{NADP}^{+}$which is proportional to aconitase activity (8). Measurements were performed with a Cobas Mira Autoanalyzer (Roche, Montclair, NJ) at $340 \mathrm{~nm}$ for $5 \mathrm{~min}$ at $37^{\circ} \mathrm{C}$. The concentration of aconitase was expressed in $\mathrm{mU} / \mathrm{ml}$ serum.

\section{Glutathione Peroxidase (GPx)}

GPx is an important antioxidant enzyme involved in the detoxification of peroxides and protecting cells from lipid peroxidation. GPx catalyzes the reduction of $\mathrm{H}_{2} \mathrm{O}_{2}$ to water. GPx was measured in welder and control serum samples with a Cobas Mira Autoanalyzer (Roche, Montclair, NJ) using a detection kit programmed according to manufacturer's protocol at an absorbance of $340 \mathrm{~nm}$. All the reagents were made fresh at the time of use, and the enzyme activity was calculated from a constructed standard curve. GPx was expressed as the amount of enzyme that transformed one $\mu \mathrm{mol}$ of NADPH to NADP per minute at $37^{\circ} \mathrm{C}$.

\section{Manganese-Superoxide Dismutase (Mn-SOD)}

Activity of Mn-SOD in the serum samples was measured using a superoxide dismutase assay kit (Cayman, Ann Arbor, MI) according to the protocol of the manufacturer. For analysis, $10 \mu \mathrm{l}$ of serum samples were treated with $190 \mu \mathrm{l}$ of tetrazolium and $10 \mu \mathrm{l}$ of $1 \mathrm{mM}$ potassium cyanide to inhibit both $\mathrm{Cu} / \mathrm{Zn}-\mathrm{SOD}$ and extracellular SOD. The reaction was initiated by adding $20 \mu \mathrm{l}$ of xanthine oxidase 
followed by incubation for $20 \mathrm{~min}$ at room temperature. Absorbance change was read at $450 \mathrm{~nm}$, using a microplate reader. The activity of Mn-SOD (U/ml) was calculated from a standard curve constructed with known amounts of standards processed with samples. Mn-SOD activity was defined as the amount of enzyme needed to exhibit $50 \%$ dismutation of the superoxide radical and was expressed as $\mathrm{U} / \mathrm{ml}$ serum.

\section{Chemiluminescence (CL)}

Potential to cause oxidative activity by the generation of free radicals by the serum of welders and non-exposed controls was determined by monitoring luminolmediated $\mathrm{CL}$. The reaction mixture contained $10 \mu \mathrm{l}$ serum and $0.1 \mathrm{mM}$ luminol in $10 \mathrm{mM}$ sodium phosphate buffer $\left(\mathrm{pH}\right.$ 7.4). The reaction was initiated by the addition of $\mathrm{H}_{2} \mathrm{O}_{2}$ at a final concentration of $1 \mathrm{mM}$ using an automatic injector. CL was measured for $10 \mathrm{~min}$ with a microplate luminometer (Berthold Technologies, Bad Wildbad, Germany). CL under different experimental conditions was performed to serve as baseline controls for ROS generation by omitting serum, $\mathrm{H}_{2} \mathrm{O}_{2}$, luminol or catalase. To confirm the generation of ROS, catalase was added to the reaction and CL generation monitored. Addition of catalase resulted in the inhibition of more than $80 \%$ of CL (data not shown). The reaction was performed at $37^{\circ} \mathrm{C}$, and values were expressed in relative light unit (RLU).

\section{Lipid Peroxidation}

Oxidation of tissue phospholipids by non-enzymatic random oxidation by free radicals produces isoprostane, and changes in isoprostane levels are considered good markers of oxidative injury (9). Using an ELISA kit (Cayman, Ann Arbor, MI), 8isoprostane in the serum of welders and controls was measured according to the manufacturer's protocol in duplicate samples. The method is a competitive enzymelinked assay for determining 8-isoprostane in biological samples using an 8-isoprostane- 
acetylcholinesterase (AChE) conjugate for a limited number of 8-isoprostane-specific rabbit antiserum binding sites. For analysis, the serum samples were diluted 1:25 and then $50 \mu \mathrm{l}$ of sample, $50 \mu \mathrm{l}$ of isoprostane AChE and $50 \mu \mathrm{l}$ of 8-isoprostane antiserum were incubated in the antibody-coated wells for $18 \mathrm{hr}$ at room temperature. The plate was washed to remove unbound reagents and then treated with Ellman's reagent containing AChE substrate for one hr. A distinct yellow color developed by enzymatic reaction is read at $412 \mathrm{~nm}$, using a microplate spectrophotometer with standards and controls treated similarly (Molecular Devices, Sunnyvale, CA). The intensity of color produced, which was inversely proportional to the amount of isoprostane produced, was calculated from a standard curve and expressed as $\mathrm{pg} / \mathrm{ml}$ serum.

Heat Shock Protein 70

An anti-human Hsp70 (lgG/A/M) enzyme-linked immunosorbent assay (ELISA) kit (Stressgen, Victoria, BC, Canada) was used to determine the amount of $\lg G, \lg A$ and IgM antibodies to human Hsp70 in serum samples from welders and controls. Briefly, the serum samples were diluted to $1: 500$ using sample diluent, and $100 \mu \mathrm{l}$ of samples were added to each well and then incubated at room temperature for $2 \mathrm{hr}$. After four washes, anti-human GAM-HRP conjugate was added and incubated for $1 \mathrm{hr}$ at $37^{\circ} \mathrm{C}$. After four washes, TMB substrate and acid stop solution were added to develop color. Absorbance was measured at $450 \mathrm{~nm}$ using a microplate spectrophotometer (Molecular Devices, Sunnyvale, CA). The concentrations of the Hsp70 (ng/ml) in serum samples were calculated from a constructed standard curve with known concentrations of Hsp 70.

\section{Statistical Analysis}

In population studies of welders and unexposed controls analysis variables were analyzed using two-way analysis of variance (ANOVA) with welding duration and 
smoking status as classification variables. Subjects were classified into groups based on the number of years employed as welder as follows; 0 years, 1-10 yrs, 11-20 yrs and $>20$ years. Smoking status was included in the analysis as well as using two categories as follows; ever smoked and never smoked. Post-hoc comparisons, were made using Fishers LSD, and all differences were considered significant at $p<0.05$. Data presented are the means \pm SE of values using a one-way ANOVA with welding exposure as the independent variable. Additional statistical models were evaluated to determine if the age of the individual could account for differences between groups on various variables. Incorporation of age into models did not substantially change the results for most of the variables. 


\section{REFERENCE}

1. Mosmann T. Rapid colorimetric assay for cellular growth and survival: Application to proliferation and cytotoxicity assays. J Immun Meth 65: 55-63, 1983.

2. Vallyathan V, Castranova V, Pack D, Leonard S, Shumaker J, Hubbs AF, Shoemaker DA, Ramsey DM, Pretty JR, McLaurin JL, Khan A, Teass A. Freshly fractured quartz inhalation leads to enhanced lung injury and inflammation. Potential role of free radicals. Am J Respir Crit Care Med 152:1003-9, 1995.

3. Ding M, Shi X, Lu Y, Huang C, Leonard S, Roberts J, Antonini J, Castranova V, Vallyathan V. Induction of activator protein-1 through reactive oxygen species by crystalline silica in JB6 cells. J Biol Chem 276:9108-14. 2001.

4. Somji S, Todd JH, Sens MA, Garrett SH, Sens DA. Expression of the constitutive and inducible forms of heat shock protein 70 in human proximal tubule cells exposed to heat, sodium arsenite, and CdCl. Environ Health Perspect 107:887-93, 1999.

5. Ding M, Shi X, Lu Y, Huang C, Leonard S, Roberts J, Antonini J, Castranova V, Vallyathan V. Induction of activator protein-1 through reactive oxygen species by crystalline silica in JB6 cells. J Biol Chem. 276(12):9108-14, 2001.

6. Zeidler PC, Roberts JR, Castranova V. Response of alveolar macrophages from inducible nitric oxide synthase knockout or wild-type mice to an in vitro lipopolysaccharide or silica exposure: J Toxicol and Environ Health. Part A. 66:9951013, 2003

7. Miller NJ, Rice-Evans C, Davies MJ, Gopinathan V, Milner A. A novel method for measuring antioxidant capacity and its application to monitoring the antioxidant status in premature neonates. Clin Sci 1993;84:407-412. 
8. Kennedy MC, Antholine WE, Beinert H. An EPR investigation of the products of the reaction of cytosolic and mitochondrial aconitases with nitric oxide. J Biol Chem $1997 ; 272: 20340-20347$.

9. Morrow JD, Roberts LJ. The isoprostanes: unique bioactive products of lipid peroxidation. Prog Lipid Res 1997;36:1-21. 


\section{CHAPTER I}

COMPARATIVE CYTOTOXICITY OF METALS AND THEIR CORRELATION WITH FREE RADICAL GENERATION, AND HEAT SHOCK PROTEIN EXPRESSION IN A HUMAN BRONCHIAL EPITHELIAL CELL LINE, BEAS-2B 


\section{INTRODUCTION}

Several toxic heavy metals such as arsenic (As), chromium (Cr), cadmium (Cd), manganese $(\mathrm{Mn})$, mercury $(\mathrm{Hg})$, nickel $(\mathrm{Ni})$, and vanadium $(\mathrm{V})$, are widely used in industrial settings, and occupational exposure to these metals is associated with the development of several pulmonary diseases (1). The adult human lung, providing an enormous surface area of approximately $140 \mathrm{~m}^{2}$ to outside direct ambient air contact, is a major target organ to toxic agents to interact either directly or systemically when exposed to metals. Several of the toxic metals such as $\mathrm{As}, \mathrm{Cr}, \mathrm{Cd}, \mathrm{Mn}, \mathrm{Ni}$, and $\mathrm{V}$ have oxidative potential (2-4). Oxidative stress induced by the generation of ROS by these metals makes the lung vulnerable to a wide spectrum of oxidative damage and disease development (2-4). Therefore, to investigate the comparative potential of these metals to induce cytotoxicity and apoptosis, and to correlate with the generation of reactive oxygen species (ROS) they were tested using a normal human bronchial epithelial cell line, BEAS-2B. Because Hsp70 over-expression was observed as an early sensitive biomarker of cellular stress (5), a comparative study of Hsp70 expression by all these metals was undertaken. 


\section{RESULTS}

Cytotoxicity of Toxic Heavy Metals to BEAS-2B Cells

Seven toxic heavy metals including $\mathrm{As}, \mathrm{Cr}, \mathrm{Cd}, \mathrm{Hg}, \mathrm{Ni}, \mathrm{V}$, and $\mathrm{Mn}$ were used to test cytotoxicity. MTT assay was performed to determine the cytotoxic effects of these metals in human bronchial epithelial cell line BEAS-2B, with $50 \mu \mathrm{M}$ concentrations of these metals for $24 \mathrm{hr}$ (Fig. 1). After $24 \mathrm{hr}$ of metal exposure, significant numbers of cells were killed by all the metals tested. Cr was the most toxic ( $<1 \%$ of survival rate), and $\mathrm{As}, \mathrm{Cd}$, and $\mathrm{Mn}$ treatment resulted in less than $50 \%$ of cell survival while $\mathrm{Hg}, \mathrm{Ni}$, and $\mathrm{V}$ were relatively less toxic ( $>50 \%$ of survival rate) than others.

\section{Apoptosis of BEAS-2B Cells to Toxic Heavy Metals}

Apoptotic cell death caused by toxic heavy metals was observed based on the presence of condensed nuclei upon treatment with Hoechst 33342 dye (Molecular Probes, Eugene, OR) that emit blue fluorescence (Fig. 2). Cells were exposed to seven different metals at $50 \mu \mathrm{M}$ for $4 \mathrm{hr}$. Significant increase of apoptotic death was shown in all the metals tested compared to control, however $\mathrm{Cr}$ (6.9-fold), As (3.2-fold), Cd (3.5fold), and $\mathrm{Hg}$ (3.6-fold) were relatively the strongest apoptosis-inducing metals. $\mathrm{Ni}, \mathrm{Mn}$, and $\mathrm{V}$ also induced a significant 2.3 to 2.6 -fold increase of apoptotic cell death.

\section{Expression of Hsp70 Protein by Metal Exposure}

The expression of Hsp70 protein was determined after exposing BEAS-2B cells to seven toxic heavy metals for $6 \mathrm{hr}$, followed by recovery periods of $12 \mathrm{hr}$. Western blot analysis showed no increase of $\mathrm{Hsp} 70$ protein by exposure to $\mathrm{Cr}, \mathrm{Ni}, \mathrm{V}$, and $\mathrm{Mn}$ at $0-200$ uM concentrations (Fig. 3A). However, there was a significant increase of Hsp70 protein by $\mathrm{As}, \mathrm{Cd}$, and $\mathrm{Hg}$ exposure (Fig. 3B). Hsp70 protein was increased approximately 11, 
10, and 6-fold at $50 \mathrm{uM}$ of $\mathrm{As}, \mathrm{Cd}$ and $\mathrm{Hg}$ exposure, respectively, following a $6 \mathrm{hr}$ exposure and a $12 \mathrm{hr}$ recovery period (Fig. 3B). The maximum accumulation of Hsp70 was observed at $20 \mu \mathrm{M}$ Cd exposure.

Effect of actinomycin D on Hsp70 protein synthesis in As, Cd, and Hg exposed cells

Actinomycin $D$ is an antibiotic that inhibits cell proliferation by interfering with DNA-dependent RNA synthesis. BEAS-2B cells were pre-treated with actinomycin D for $30 \mathrm{~min}$ followed by exposure to three metals (As, Cd, and $\mathrm{Hg}$ ) for $3 \mathrm{hr}$. After a $12 \mathrm{hr}$ recovery with fresh media, Hsp70 expression was observed using Western blot analysis. The increase in Hsp70 protein synthesis was largely blocked by the action of actinomycin D (Fig. 4). This result demonstrates that the expression of Hsp70 protein is regulated at the level of transcription.

Generation of Hydroxyl Radicals $(\mathrm{OH})$ by various metals

In an effort to investigate the mechanisms by which metals induce ROS generation, we exposed BEAS-2B cells to $100 \mu \mathrm{M}$ of various metals for $10 \mathrm{~min}$ in the presence of DMPO and phosphate buffer at $37^{\circ} \mathrm{C}$. ESR spectra, recorded $10 \mathrm{~min}$ after the initiation of reaction at a $\mathrm{pH} 7.4$ in phosphate buffer containing $200 \mathrm{mM}$ DMPO and various metals, showed a typical 1:2:2:1 quartet with hyperfine splittings of $a_{H}=a_{N}=$ $14.9 \mathrm{G}$. Based on these splitting constants of hydrogen and nitrogen, the signal was assigned to a $\mathrm{DMPO} /{ }^{\circ} \mathrm{OH}$ adduct, demonstrating the generation of ${ }^{\circ} \mathrm{OH}$ radicals. Figure 5 shows typical ESR spectra generated from mixtures containing DMPO, cells, and various metals. Control experiments without the addition of cells with equivalent volumes of DMPO did not develop significant signal intensity, implying that the effect was not due its reactants. Also, cells with DMPO and no added metals failed to produce the ${ }^{\circ} \mathrm{OH}$ signal. However, $\mathrm{Cr}$ with DMPO produced a strong DMPO/ ${ }^{\circ} \mathrm{OH}$ signal, while 
other metals showed weak signals. These data demonstrate that the seven toxic metals investigated have catalytic properties by which ROS can be generated, and the ROS generation potential is markedly different based on their own chemical properties. 


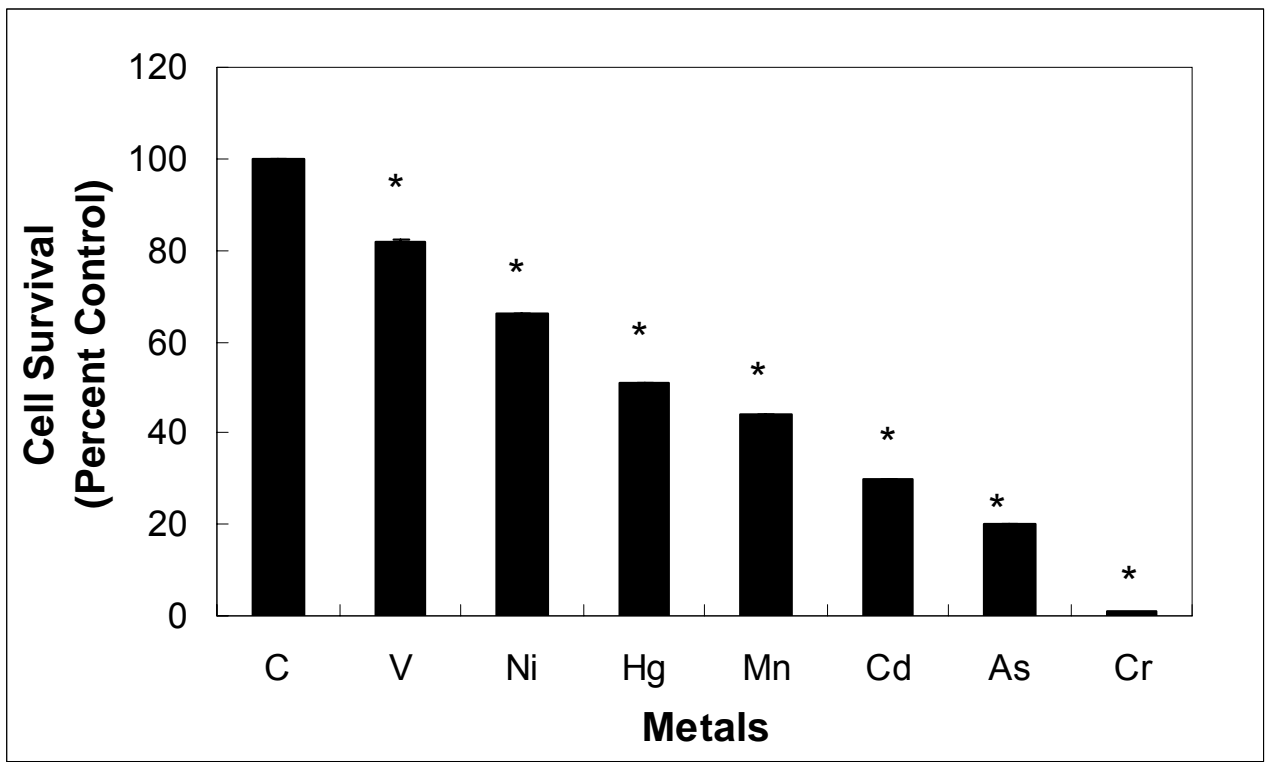

Figure 1. MTT cytotoxicity test in BEAS-2B cells by metal exposure. BEAS-2B cells were seeded in 96 -well plates at a $2 \times 10^{4}$ cell/well and incubated for $24 \mathrm{hr}$. The medium was changed, and cells were exposed in triplicate to metals $(50 \mu \mathrm{M})$ for 1 day. The optical density was measured at $570 \mathrm{~nm}$, and values presented represent the mean \pm SE of six assay wells from two independent experiments. * Indicates a significant decrease of cell viability from control $(p<0.05)$. 


\section{A}

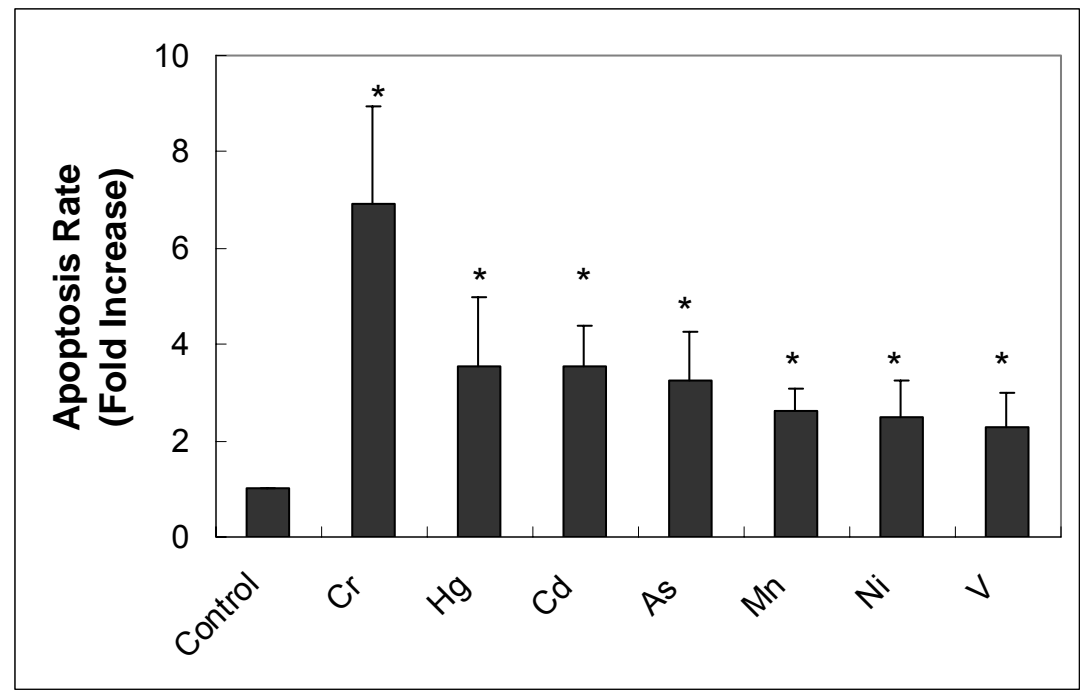

B

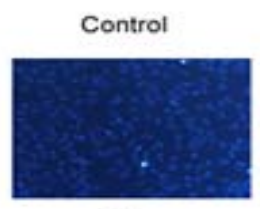

As

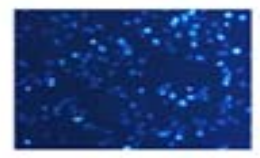

$\mathrm{Cr}$

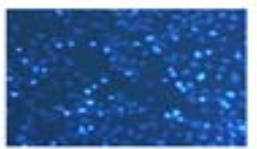

Mn

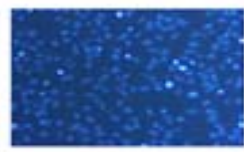

$\mathrm{Hg}$

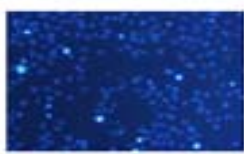

$\mathrm{Ni}$

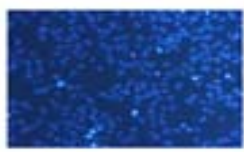

Cd

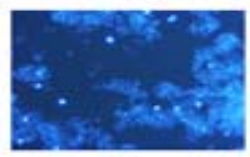

V

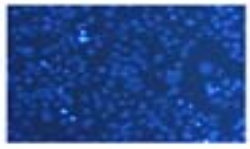

Figure 2. Apoptosis of BEAS-2B cells determined by Hoechst dye. BEAS-2B cells were seeded in 12-well plates at $2 \times 10^{5}$ cell/well and incubated for $24 \mathrm{hr}$. Cells were exposed to various metals $(50 \mu \mathrm{M})$ for $4 \mathrm{hr}$. Apoptotic cells (shown by bright blue nuclear fluorescence) were revealed by staining with Hoechst 33342 dye. (A) Quantitative results from two independent studies. (B) Fluorescence microphotographs of one typical experiment. *Indicates a significant increase of apoptosis compared to control $(p<0.05)$. 

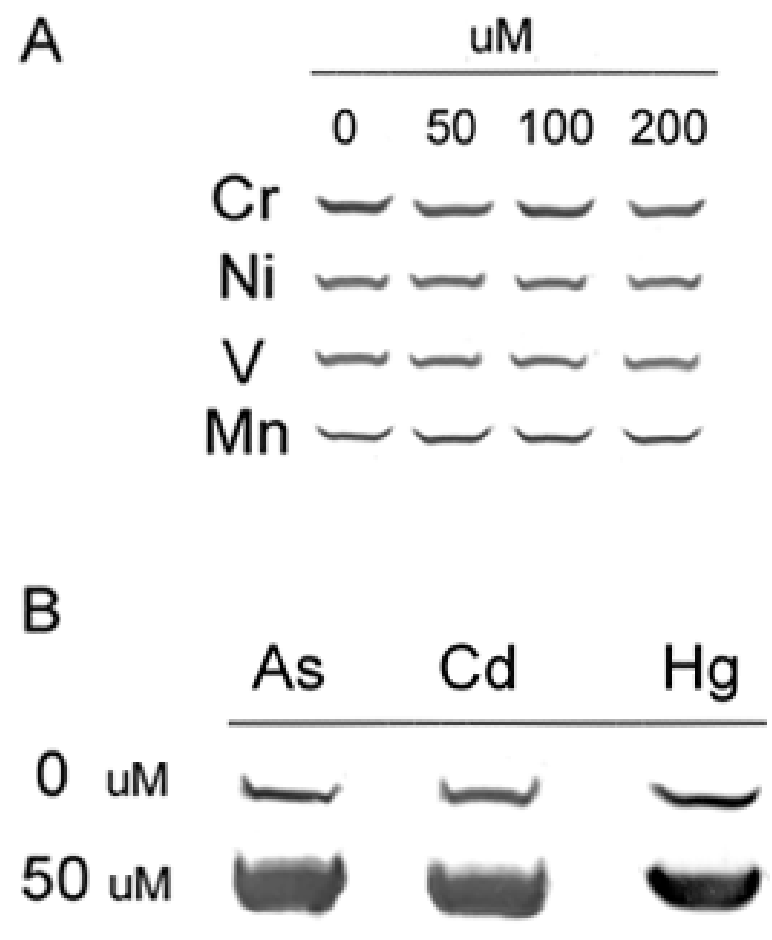

Figure 3. Hsp70 protein detection by Western blotting. BEAS-2B cells were exposed to various metals for $6 \mathrm{hr}$, followed by recovery with fresh media for $12 \mathrm{hr}$. Cells were harvested and $30 \mu \mathrm{g}$ of total protein samples separated by $10 \%$ SDS-PAGE were transferred onto $0.2 \mu \mathrm{m}$ nitrocellulose membranes. Western blotting was performed with the anti-Hsp70 monoclonal antibody. 


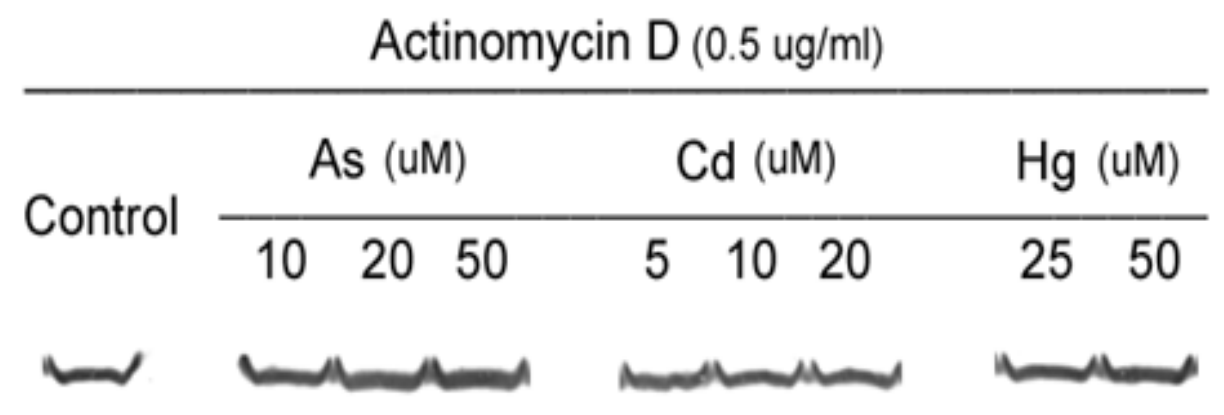

Figure 4. Effect of actinomycin D on Hsp70 protein expression in BEAS-2B cells exposed to As, Cd, and Hg. BEAS-2B cells were pretreated with actinomycin D with final concentration of $0.5 \mu \mathrm{g} / \mathrm{ml}$. Cells were then exposed to As, Cd, and $\mathrm{Hg}$ for $3 \mathrm{hr}$, followed by recovery with fresh media for $12 \mathrm{hr}$. Western blotting was performed with the anti-Hsp70 monoclonal antibody. 

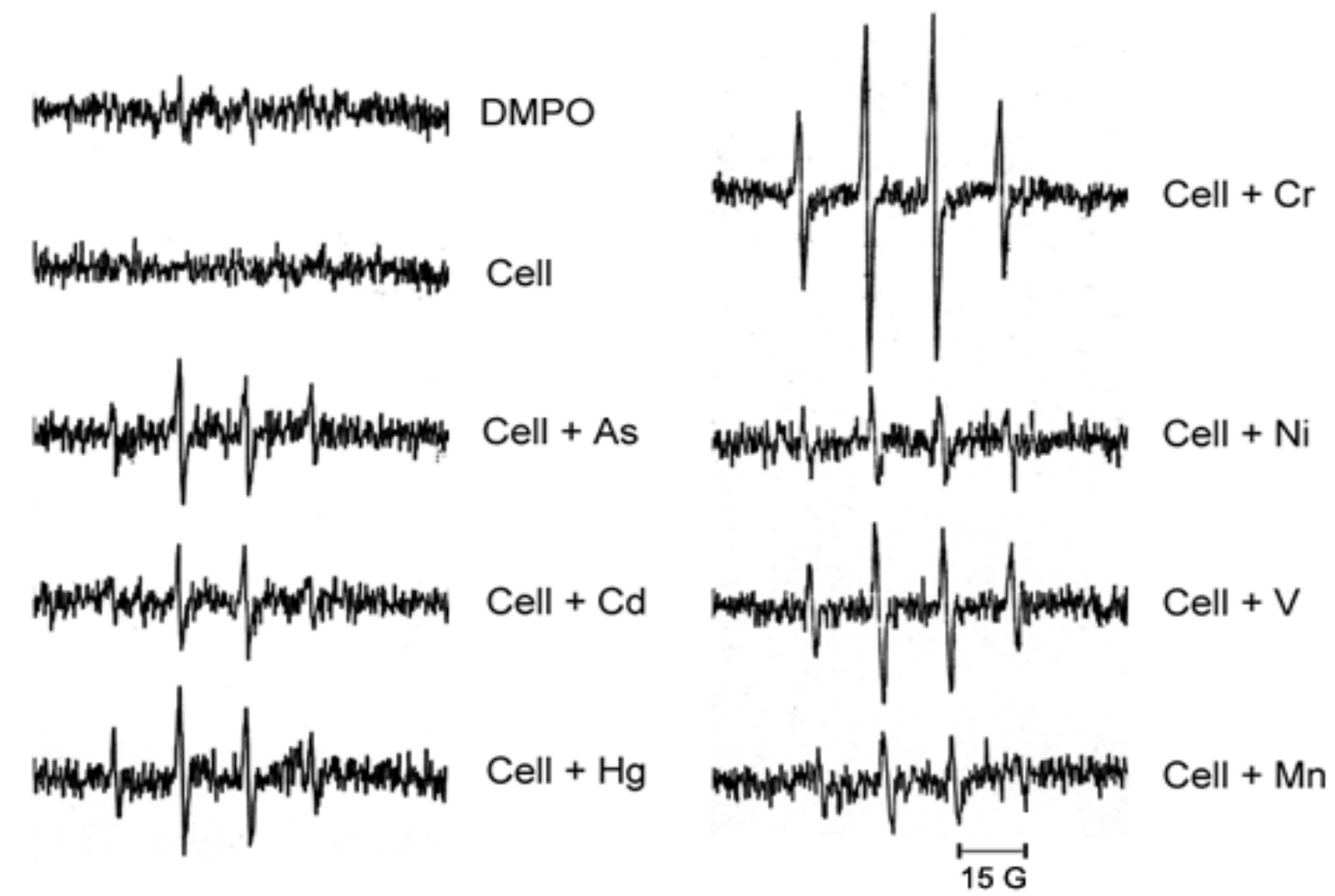

Figure 5. Comparative ESR spectra obtained from BEAS-2B cells exposed to $\mathrm{As}, \mathrm{Cd}, \mathrm{Cr}, \mathrm{Hg}, \mathrm{Mn}, \mathrm{Ni}$, and $\mathrm{V}$. DMPO/ ${ }^{\circ} \mathrm{OH}$ adducts document the generation of $\mathrm{OH}$ radicals. BEAS-2B cells $\left(1 \times 10^{6}\right)$ were incubated with $200 \mathrm{mM}$ of DMPO and 100 $\mu \mathrm{M}$ of various metals for $10 \mathrm{~min}$ at $37^{\circ} \mathrm{C}$. The spectra were integrated by 3 scans. The spectrometer settings were: receiver gain, $6.32 \times 10^{4}$; time constant, $40.960 \mathrm{~ms}$; modulation amplitude, $1.0 \mathrm{G}$; scan time, $41.943 \mathrm{~s}$; magnetic field, $3490 \pm 50 \mathrm{G}$. 


\section{DISCUSSION}

In this chapter, the toxic effects of seven heavy metals (As, Cd, $\mathrm{Cr}, \mathrm{Hg}, \mathrm{Mn}, \mathrm{Ni}$, and V) were compared, using a normal human bronchial epithelial cell line, BEAS-2B. All metals were cytotoxic and induced apoptosis in BEAS-2B cells. However, the comparative toxicities of these seven metals showed significant differences in terms of the degree of toxicity.

In cytotoxicity studies $\mathrm{Cr}$ was significantly cytotoxic and $\mathrm{V}$ was the least cytotoxic to BEAS-2B cells. In ranking of the toxicity $\mathrm{Cr}$ was the most cytotoxic and $\mathrm{V}$ was the least cytotoxic and other metals are presented in decreasing order of $\mathrm{Cr}>\mathrm{As}>\mathrm{Cd}>\mathrm{Mn}$ $>\mathrm{Hg}>\mathrm{Ni}>\mathrm{V}$. Apoptotic cell death was significantly higher in decreasing order of $\mathrm{Cr}>\mathrm{Hg}$ $>\mathrm{Cd}>\mathrm{As}>\mathrm{Mn}>\mathrm{Ni}>\mathrm{V}$ in BEAS-2B cells. In cytotoxicity as well as apoptosis $\mathrm{Cr}$ was the most toxic metal compared to others. This corresponded also with the potential of $\mathrm{Cr}$ to generate ROS as seen from the result of ESR experiments demonstrating $\mathrm{Cr}$ as the most powerful inducer $\cdot \mathrm{OH}$ radicals upon interaction with BEAS-2B cells under similar experimental conditions and concentrations. It has been documented that transition metals can contribute oxidation of biomolecules leading to oxidative tissue damage (4). These metals can increase ROS generation such as ${ }^{\circ} \mathrm{OH}, \mathrm{H}_{2} \mathrm{O}_{2}$, and $\mathrm{O}_{2}{ }^{-}$. $\mathrm{Cr}(\mathrm{VI})$ is the most toxic metal because $\mathrm{Cr}(\mathrm{VI})$ is absorbed much better than $\mathrm{Cr}(\mathrm{III})$, and its conversion into $\mathrm{Cr}$ (III) generates various unstable toxic intermediates such as $\mathrm{Cr}(\mathrm{V})$, and $\mathrm{Cr}$ (IV). Our ESR studies also demonstrated that all seven metals can cause an increase of ROS generation. The potential to generate ROS was greatest with $\mathrm{Cr}$ and decreased in the order $\mathrm{Cr}>\mathrm{V}>\mathrm{Hg}>\mathrm{As}>\mathrm{Cd}>\mathrm{Ni}>\mathrm{Mn}$. These findings corroborate with other studies reported in literature showing that $\mathrm{Cr}(\mathrm{VI})$ and chromium intermediates are the most species with the potential to generate ROS through cycling with sustained enhanced redox potential (6). ROS generated by $\mathrm{Cr}$ can cause a variety of toxic effects including 
DNA damage, lipid damage, and protein damage. Although other metals also showed evidence for ROS generation in ESR experiments, the relative levels of ROS generation potential was significantly smaller compared to $\mathrm{Cr}(\mathrm{VI})$ and $\mathrm{V}$, probably because they are redox-inactive metals (7).

It has been documented that ROS produced by metal exposure act to elevate the expression of stress proteins (8). Our study showed that enhanced expressions of Hsp70 by BEAS-2B cells caused only with exposure of As, Cd and $\mathrm{Hg}$. These three metals are redox-inactive metals with the potential to produce oxidative stress by the depletion of antioxidants and binding to SH groups and proteins $(8,11)$. Therefore, these studies suggest that Hsp70 induction is mainly through oxidative stress generated by the lack of antioxidant balance and depletion of $\mathrm{SH}$ groups and through some other mechanisms leading to denatured intracellular proteins. The oxidative stress resulting from these metal-induced ROS generation and denatured proteins may enhance the activity of heat shock factor 1 (HSF1) resulting in the binding of heat shock element (HSE) to induce the Hsp70 gene expression (9-12). However, from these studies it can be hypothesized that the relationship between generation of ROS and induction of Hsp70 is probably not the direct cause and effect mechanism. $\mathrm{Cr}$ and $\mathrm{V}$, which had the greatest potential to generate ROS, indued no increase in Hsp70 expression even at much higher concentrations. Therefore the complex mechanisms involved in the ability of these three metals to induce the expression of Hsp70 remains to be elucidated. Results presented here also suggest that the expression of Hsp70 is regulated at the level of transcription. The data also indicate that all the seven metals studied have a potential to generate ROS and can induce toxic effects through oxidative stress in human lung cell line, BEAS-2B. Oxidative stress is known to induce Hsp70 expression as a protective mechanism only in the cells exposed to $\mathrm{As}, \mathrm{Cd}$, and $\mathrm{Hg}$, and this induction is regulated at the level of transcription. 


\section{REFERENCES}

1. Jarup L. Hazards of heavy metal contamination. Br Med Bull. 2003;68:167-82.

2. Harris GK, Shi $X$. Signaling by carcinogenic metals and metal-induced reactive oxygen species. Mutat Res. 2003 Dec 10;533(1-2):183-200.

3. Galaris D, Evangelou A. The role of oxidative stress in mechanisms of metalinduced carcinogenesis. Crit Rev in Oncol Hemato. 2002;42:93-103.

4. Ercal N, Gurer-Orhan H, Aykin-Burns N. Toxic metals and oxidative stress part I: mechanisms involved in metal-induced oxidative damage. Curr Top Med Chem. 2001 Dec;1(6):529-39.

5. Delmas F, Trocheri V, Miro C, Villaescusa I, Murat JC. Expression of stress proteins in cultured human cells as a sensitive indicator of metal toxicity. Fresenius $\mathrm{J}$ Anal Chem. 354: 615-619, 1996.

6. Ding M, Shi X, Castranova V, Vallyathan V. Predisposing factors in occupational lung cancer: inorganic minerals and chromium. J Environ Pathol Toxicol Oncol. 2000;19(1-2):129-38.

7. Stohs SJ, Bagchi D. Oxidative mechanisms in the toxicity of metal ions. Free Radic Biol Med 1995;18(2):321-336.

8. Del Razo LM, Quintanilla-Vega B, Brambila-Colombres E, Calderon-Aranda ES, Manno M, Albores A. Stress proteins induced by arsenic. Toxicol Appl Pharmacol $177: 132-48,2001$.

9. Knauf U, Newton EM, Kyriakis J, Kingston RE. Repression of human heat shock factor 1 activity at control temperature by phosphorylation. Genes Dev. 1996 Nov $1 ; 10(21): 2782-93$

10. Mivechi NF, Koong AC, Giaccia AJ, Hahn GM. Analysis of HSF-1 phosphorylation in A549 cells treated with a variety of stresses. Int J Hyperthermia. 1994 MayJun;10(3):371-9. 
11. Santoro MG. Heat shock factors and the control of the stress response. Biochem Pharmacol. 2000 Jan 1;59(1):55-63.

12. Nishizawa J, Nakai A, Matsuda K, Komeda M, Ban T, Nagata K. Reactive oxygen species play an important role in the activation of heat shock factor 1 in ischemicreperfused heart. Circulation. 1999 Feb 23;99(7):934-41. 
CHAPTER II

HSP70 EXPRESSION AND REACTIVE OXYGEN SPECIES GENERATION IN HUMAN BRONCHIAL CELL LINE, BEAS-2B, CAUSED BY EXPOSURE TO ARSENIC 


\section{INTRODUCTION}

Based on the results of Chapter I, the mechanisms of Hsp70 upregulation were further studied. The aim of this investigation was to analyze the mechanisms involved in Hsp70 induction, as well as the level of Hsp70 expression by exposure to trivalent arsenic $\left(\mathrm{AsCl}_{3}\right)$ using human bronchial epithelial cell line, BEAS-2B. Thus, in this study, the relationship of As exposure and the levels of Hsp70 expression were investigated in correlation with ROS generation. Several indicators for ROS generation were used. Also, an attempt was made to determine whether As-induced molecular and cellular mechanisms correlate with corresponding changes in the secretion of Hsp70. If results are positive, monitoring Hsp70 in workers exposed to As may prove to be a sensitive biomarker for exposure/response. 


\section{RESULTS}

Cytotoxicity of As to BEAS-2B Cells

To determine the cytotoxic effects and to select optimal concentrations without causing significant cytotoxicity to As in human bronchial epithelial cell line BEAS-2B, we performed the MTT assay with different concentrations of arsenic for different time periods (Fig. 6). Cytotoxicity resulting from As was increased in a dose and time dependent manner during the 3 day exposure period. On day one, the survival rate was decreased to 86,52 and $24 \%$ at 10,20 , and $50 \mu \mathrm{M}$ concentrations of As, respectively. On day two, the survival rate was further decreased to 30,19 and $5 \%$ in $10,20,50 \mu \mathrm{M}$ concentrations of As, respectively, compared to control. On day three, almost all of the cells were killed in the presence of As compared to control. The analysis of cytotoxicity data indicated a decrease in cell viability beginning at $24 \mathrm{hr}$ exposure to arsenic. Cytotoxicity continued to increase substantially at day two and three. Therefore, this dose and time-dependent cytotoxicity was taken into consideration in all further studies.

Expression of Hsp70 Protein is Increased in a Dose-dependent Manner by As Exposure

The expression of Hsp70 protein was determined after exposing BEAS-2B cells to As for 6 and $12 \mathrm{hr}$, followed by recovery periods (0-12 hr). Western blot analysis showed a significant increase in Hsp70 protein with all the As concentrations used (Fig. 7). Hsp70 protein was increased approximately $2.5,4.8$ and 9.4-fold at 10, 20 and 50 $\mu \mathrm{M}$ As concentrations, respectively, following a $6 \mathrm{hr}$ exposure and $8 \mathrm{hr}$ recovery period (Fig. 7, A). It was also increased approximately 3.7, 4.1 and 11.5-fold at 10, 20 and 50 $\mu \mathrm{M}$ concentrations of As, respectively, following a $12 \mathrm{hr}$ exposure and $8 \mathrm{hr}$ recovery period (Fig. 7, B). The maximum accumulation of Hsp70 was observed at $50 \mu \mathrm{M}$ As exposure. Note the control level of Hsp70 protein increased from $6 \mathrm{hr}$ exposure to $12 \mathrm{hr}$; 
therefore, the overall expression level after As was higher in the $12 \mathrm{hr}$ As exposed cells. To determine the Hsp70 protein accumulation over longer recovery periods, cells were recovered for 0-96 hr after $50 \mathrm{uM}$ As exposure for $6 \mathrm{hr}$ (Fig. 7, C). The maximum accumulation was achieved at 12 and $24 \mathrm{hr}$ recovery periods (over 6-fold compared to control) followed by decrease but the accumulation was still higher in the $96 \mathrm{hr}$ recovery time (over 2-fold) compared to control. The Hsp70 ELISA assay was also performed to quantify the expression of Hsp70 and verify a similar dose response with As exposure (Fig. 8). In the Hsp70 ELISA assay, the expression of Hsp70 was most prominent in the cells exposed to As for 6 and $12 \mathrm{hr}$ with a $8 \mathrm{hr}$ recovery period. Hsp70 protein expression was increased approximately $8.7,14.9$ and 22.8 -fold at 10,20 and 50 uM As concentrations, respectively, in the $6 \mathrm{hr}$ exposure and $8 \mathrm{hr}$ recovery period (Fig. 8). In the $12 \mathrm{hr}$ exposure and an $8 \mathrm{hr}$ recovery time, the expression was increased $8.3,13.5$ and 18.5-fold at 10, 20 and $50 \mu \mathrm{M}$ As concentrations, respectively (Fig. 8).

Hsp70 mRNA Expression in BEAS-2B Cells Exposed to As

The Hsp70 family of proteins is encoded by several genes, including Hsp70A, Hsp70B and Hsp70C genes (1). To investigate the effects of As exposure on the expression of these three Hsp mRNAs in BEAS-2B cell, we analyzed the expression of mRNA of the three isoforms after a $6 \mathrm{hr}$ exposure and a recovery period of $0-12 \mathrm{hr}$. The results for the expression of mRNA generated for the Hsp70A, B and C genes are presented from a typical agarose gel experiment (Fig. 9, D). Graphic illustration of the mean values from three independent experiments on the expression of these Hsp genes, compared to mRNA from the G3PDH housekeeping gene, is presented in Figures 9, A, B and C. The analysis showed that message for each Hsp70 gene had a differential expression pattern when the cells were exposed to As. Message for the Hsp70A isoform was highly expressed in all As concentrations tested. The Hsp70A mRNA 
expression was increased approximately $2.7,2.2$, and 1.9-fold at 10,20 and $50 \mu \mathrm{M}$ As concentrations, respectively, in the zero hr recovery period (Fig. 9, A). During the recovery periods of 4-12 hr, the Hsp70A mRNA expression decreased toward the control level. Hsp70B mRNA expression increased approximately 2.4-fold at $10 \mu \mathrm{M}$ concentration of As and did not increase further at a higher $50 \mu \mathrm{M}$ concentration of arsenic (Fig. 9, B). At 4-12 hours of recovery, the Hsp70B mRNA expression returned to the control level except in cells treated with the $50 \mu \mathrm{M}$ concentration of As. The expression pattern of Hsp70C mRNA was similar to that of Hsp70A mRNA. The Hsp70C mRNA expression was increased approximately 4.8, 5.2, and 6.4-fold at 10, 20 and $50 \mu \mathrm{M}$ As concentrations, respectively, after a zero hr recovery period (Fig. 9, C). Hsp70C mRNA returned to the control level by $8 \mathrm{hr}$ post exposure at 10 and $20 \mu \mathrm{M}$ As but remained elevated during the recovery period after a $50 \mu \mathrm{M}$ As treatment. From these results it is apparent that the expression of mRNA of Hsp70A, Hsp70B and Hsp70C isoforms are rapidly increased in response to As exposure.

Effect of Antioxidants and Other Reagents on As-induced Hsp70 Protein Expression by Western Blotting

I hypothesized that As-induced Hsp70 expression is mediated through ROS and that antioxidants may suppress the expression of Hsp. To test this hypothesis, the effects of antioxidants and other reagents on As-induced Hsp70 expression were investigated. BEAS-2B cells were exposed to $50 \mu \mathrm{M}$ As along with antioxidants for $6 \mathrm{hr}$ and the expression of Hsp70 was tested. The concentrations of the antioxidants and other reagents used were: catalase, 2,000 units/ml; superoxide dismutase (SOD), 2,000 units/ml; $N$-acetylcysteine (NAC), $10 \mathrm{mM}$; sodium formate (SF), $50 \mathrm{mM}$.

The effects of antioxidants and other reagents on As-induced Hsp70 expression are shown in Figure 10. Catalase, a $\mathrm{H}_{2} \mathrm{O}_{2}$-scavenging enzyme, inhibited $\mathrm{As}(\mathrm{III})$-induced 
Hsp70 protein expression by $40 \%$. SOD, a ${ }^{\circ} \mathrm{O}_{2}^{-}$radical scavenger that generates $\mathrm{H}_{2} \mathrm{O}_{2}$, and sodium formate, a ${ }^{\circ} \mathrm{OH}$ radical scavenger had some inhibitory effect approximately 28 and $34 \%$, respectively, on the induction of Hsp70 protein. $\mathrm{N}$-acetylcysteine, a thiolcontaining general antioxidant, completely inhibited the induction of Hsp70 protein to the control level. These results suggests that ROS play a role in As(III)-induced Hsp70 protein expression.

\section{Generation of Hydroxyl Radicals by As}

To test whether As induces ROS generation, I exposed BEAS-2B cells to $100 \mu \mathrm{M}$ of As for $10 \mathrm{~min}$ in the presence DMPO and phosphate buffer at $37^{\circ} \mathrm{C}$. ESR spectra, recorded 10 min after the initiation of reaction at a $\mathrm{pH} 7.4$ in phosphate buffer containing $200 \mathrm{mM}$ DMPO and $100 \mu \mathrm{M}$ As, showed a typical 1:2:2:1 quartet with hyperfine splittings of $a_{H}=a_{N}=14.9 \mathrm{G}$. Based on these splitting constants of hydrogen and nitrogen, the signal was assigned to a $\mathrm{DMPO} /{ }^{\circ} \mathrm{OH}$ adduct, demonstrating the generation of ${ }^{\circ} \mathrm{OH}$ radicals. Figure 11 shows that DMPO with cells, or DMPO alone failed to produce the ${ }^{\circ} \mathrm{OH}$ signal, while As with DMPO and cells produced ${ }^{\circ} \mathrm{OH}$ radicals. The addition of catalase, a $\mathrm{H}_{2} \mathrm{O}_{2}$ decomposing enzyme, inhibited ${ }^{\circ} \mathrm{OH}$ generation substantially implying that $\mathrm{H}_{2} \mathrm{O}_{2}$ was produced in the As-treated cells. Addition of sodium formate, a ${ }^{\circ} \mathrm{OH}$ radical scavenger, decreased the signal intensity. Addition of $\mathrm{NADPH}$, a cellular reductant, significantly increased the ${ }^{\circ} \mathrm{OH}$ signal. These data suggest that As can produce ROS such as $\mathrm{H}_{2} \mathrm{O}_{2}$ and ${ }^{\circ} \mathrm{OH}$, by interaction with cells.

\section{Detection of Intracellular ROS Generation by Exposure to As using Confocal Microscopy}

Generation of ROS by As was further confirmed by confocal microscopy. BEAS2B cells were exposed to As in the presence of $\mathrm{H}_{2}$ DCFDA, a specific fluorescent dye for $\mathrm{H}_{2} \mathrm{O}_{2}$, or dihydroethidium, a specific fluorescent dye for ${ }^{\circ} \mathrm{O}_{2}^{-}$. Images are displayed in 
pseudocolor where blue indicates areas of low intensity and increasingly high intensity areas are green $<$ yellow $<$ red $<$ white. In the presence of increasing concentrations of As the intensity of fluorescence increased compared to control. To document the high intensity gradient levels of $\mathrm{H}_{2} \mathrm{O}_{2}$ and ${ }^{\circ} \mathrm{O}_{2}{ }^{-}$generated cells were exposed to 50 and 100 $\mu \mathrm{M}$ of As and results obtained are displayed (Fig. 12).

\section{Lipid Peroxidation from BEAS-2B Cells Exposed to As}

To ensure the generation of ROS, a lipid peroxidation by-product produced by cells in response to As was analyzed immediately after a $24 \mathrm{hr}$ exposure. Isoprostane is produced by the oxidation of phospholipids by oxygen radicals, and is considered an ideal marker of oxidative stress. Analysis of conditioned media from cells exposed to As showed dose-dependent, significant increases in the levels of 8-isoprostane (Fig. 13). The 8-isoprostane production was increased approximately 1.9, 3.1 and 6.6-fold at 5, 10 and $20 \mu \mathrm{M}$ As concentrations, respectively. 


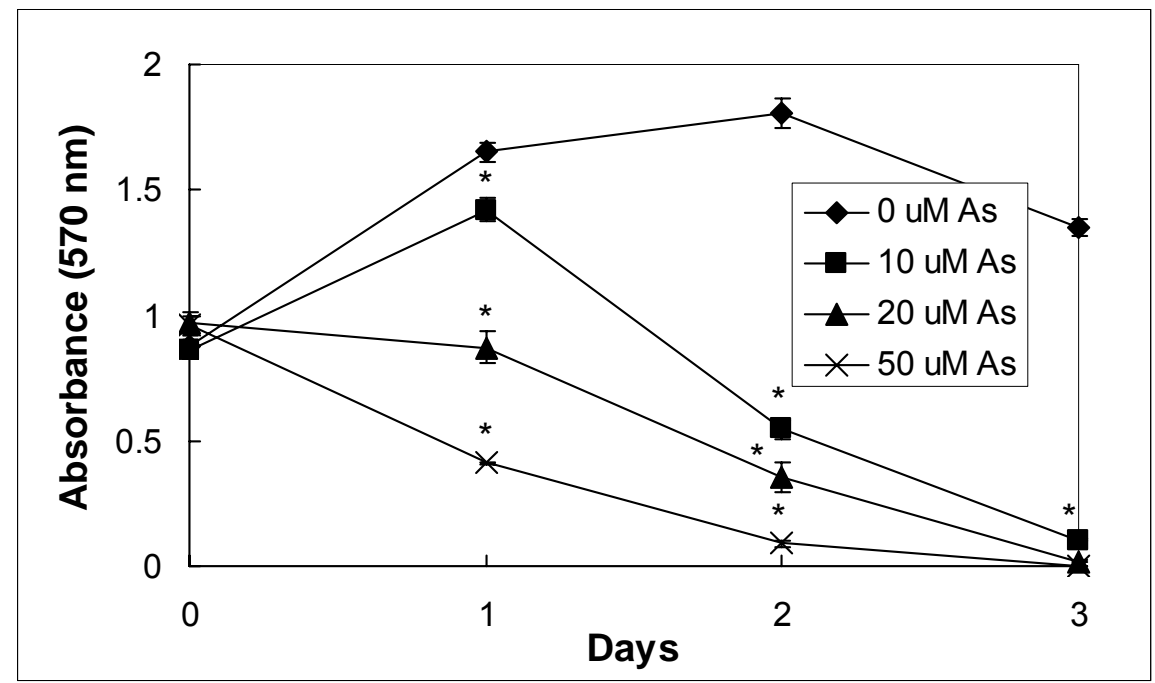

Figure 6. Cytotoxicity of As to BEAS-2B cells determined by the MTT assay. BEAS2B cells were seeded in 96 -well plates at $2 \times 10^{4}$ cell/well and incubated for $24 \mathrm{hr}$. The medium was changed, and cells in triplicate were exposed to different As $(0-50 \mu \mathrm{M})$ concentrations for 3 days. The optical density was measured at $570 \mathrm{~nm}$, and values presented represent the mean \pm SE of six assay wells from two independent experiments. *Indicates a significant decrease of cell viability from control $(p<0.05)$. 


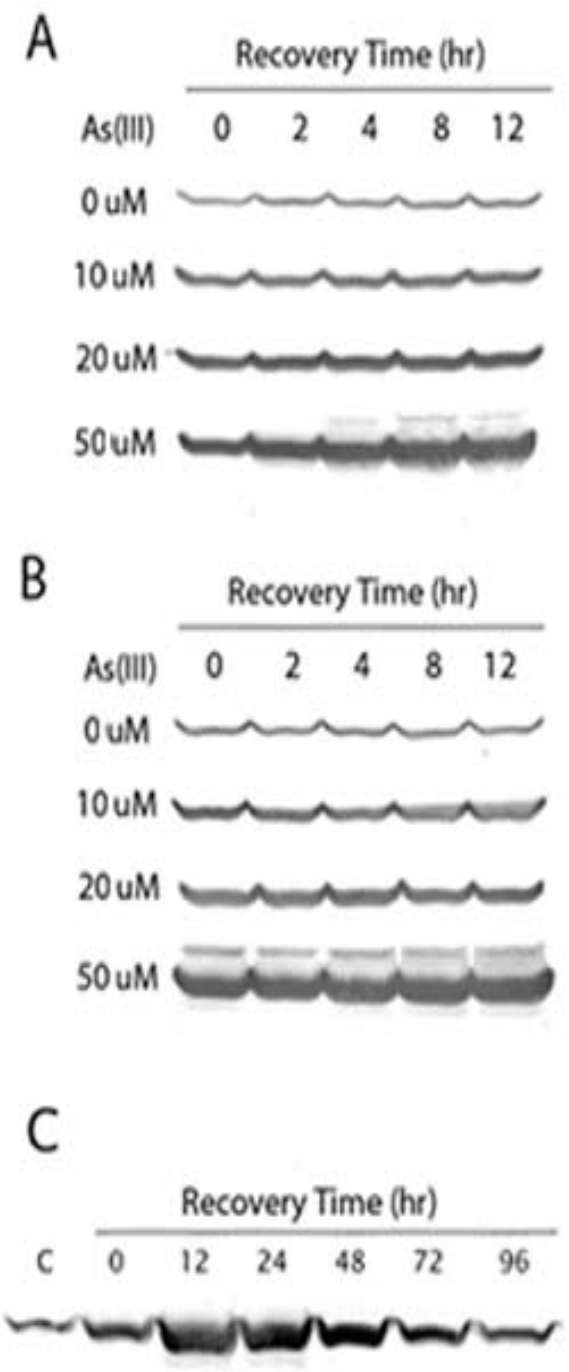

Figure 7. Hsp70 protein detection by Western blotting during recovery periods. BEAS-2B cells were exposed to As for two different times, $6 \mathrm{hr}(\mathrm{A})$ and $12 \mathrm{hr}(\mathrm{B})$, followed by recovery with fresh media for five different times periods (0-12 hr) as indicated. (C) Cells were exposed to As $(50 \mu \mathrm{M})$ for $6 \mathrm{hr}$, followed by 0-96 hr recovery periods. Cells were harvested and $30 \mu \mathrm{g}$ of total protein samples separated by $10 \%$ SDS-PAGE were transferred onto $0.2 \mu \mathrm{m}$ nitrocellulose membranes. Western blotting was performed with the anti-Hsp70 monoclonal antibody. 


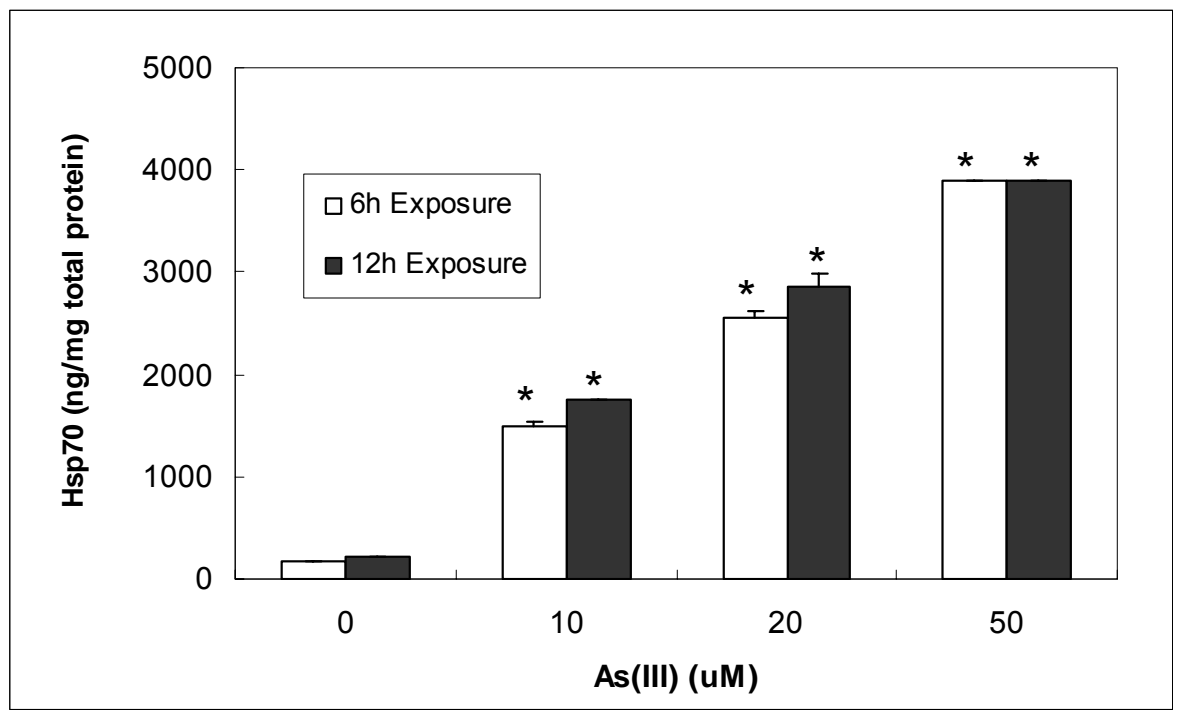

Figure 8. Hsp70 protein detection by ELISA. BEAS-2B cells were exposed to As for two different times, $6 \mathrm{hr}$ and $12 \mathrm{hr}$, followed by recovery with fresh media for $8 \mathrm{hr}$. Cells were harvested and the total protein samples $(0.025 \mu \mathrm{g} / \mu \mathrm{l})$ were tested by Hsp70 ELISA kit. The absorbance of samples was measured at $450 \mathrm{~nm}$, using a microplate spectrophotometer. The values of Hsp70 concentrations ( $\mathrm{ng} / \mathrm{mg}$ total protein) of each sample presented represent the mean \pm SE of six assay wells from two independent experiments. *Indicates a significant increase from control $(p<0.05)$. 

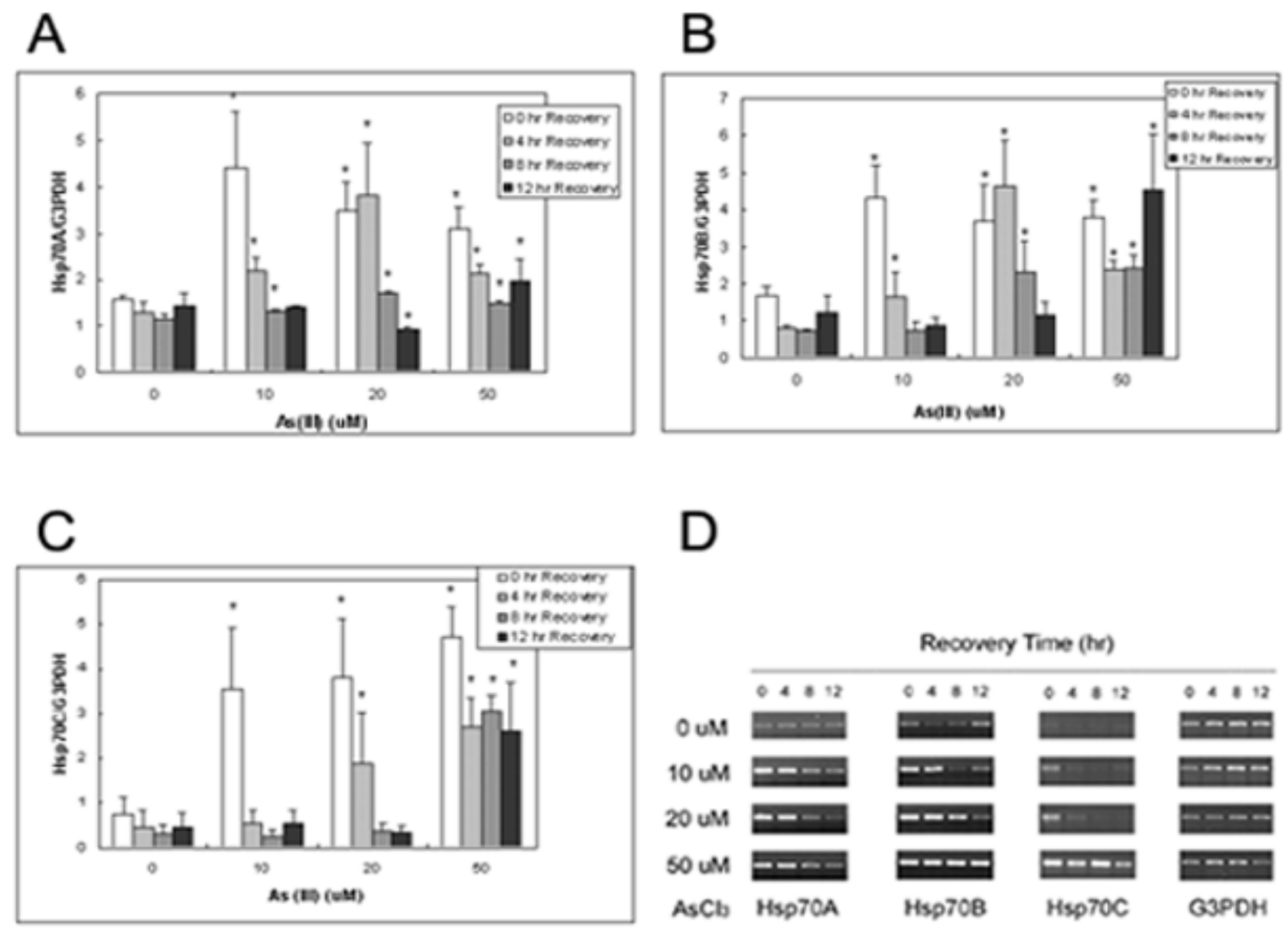

Figure 9. RT-PCR analysis of mRNA from BEAS-2B cells exposed to As. BEAS-2B cells were exposed to $0-50 \mu \mathrm{M}$ As for $6 \mathrm{hr}$, followed by a 0-12 hr recovery period. The values of $\operatorname{Hsp70A}(\mathrm{A})$, Hsp70B (B), and Hsp70C (C) mRNA expression presented represent mean \pm SE of relative integrated optical density of bands divided by that for the housekeeping gene, G3PDH, from three independent experiments. (D) A representative agarose gel picture from one of the experiments used for data analysis. *Indicates a significant increase from control $(p<0.05)$. 


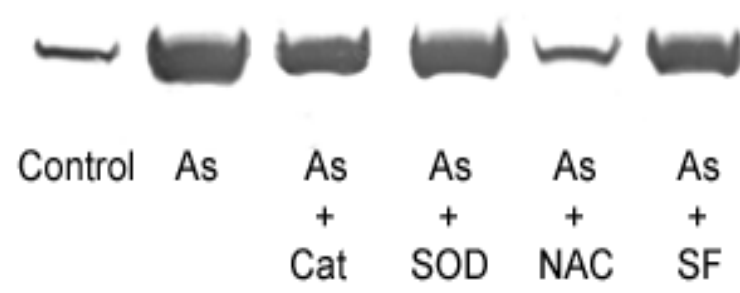

Figure 10. Effect of antioxidants and other reagents on As-induced Hsp70 protein expression by Western blotting. BEAS-2B cells were exposed to $50 \mu \mathrm{M}$ As with or without antioxidants for $6 \mathrm{hr}$. Western blotting was performed as those described in the legend to Fig 8. The concentrations of the antioxidants and other reagents used were: catalase, 2,000 units/ml; superoxide dismutase (SOD), 2,000 units $/ \mathrm{ml} ; \mathrm{N}$-acetylcysteine (NAC), $10 \mathrm{mM}$; sodium formate (SF), $50 \mathrm{mM}$. 


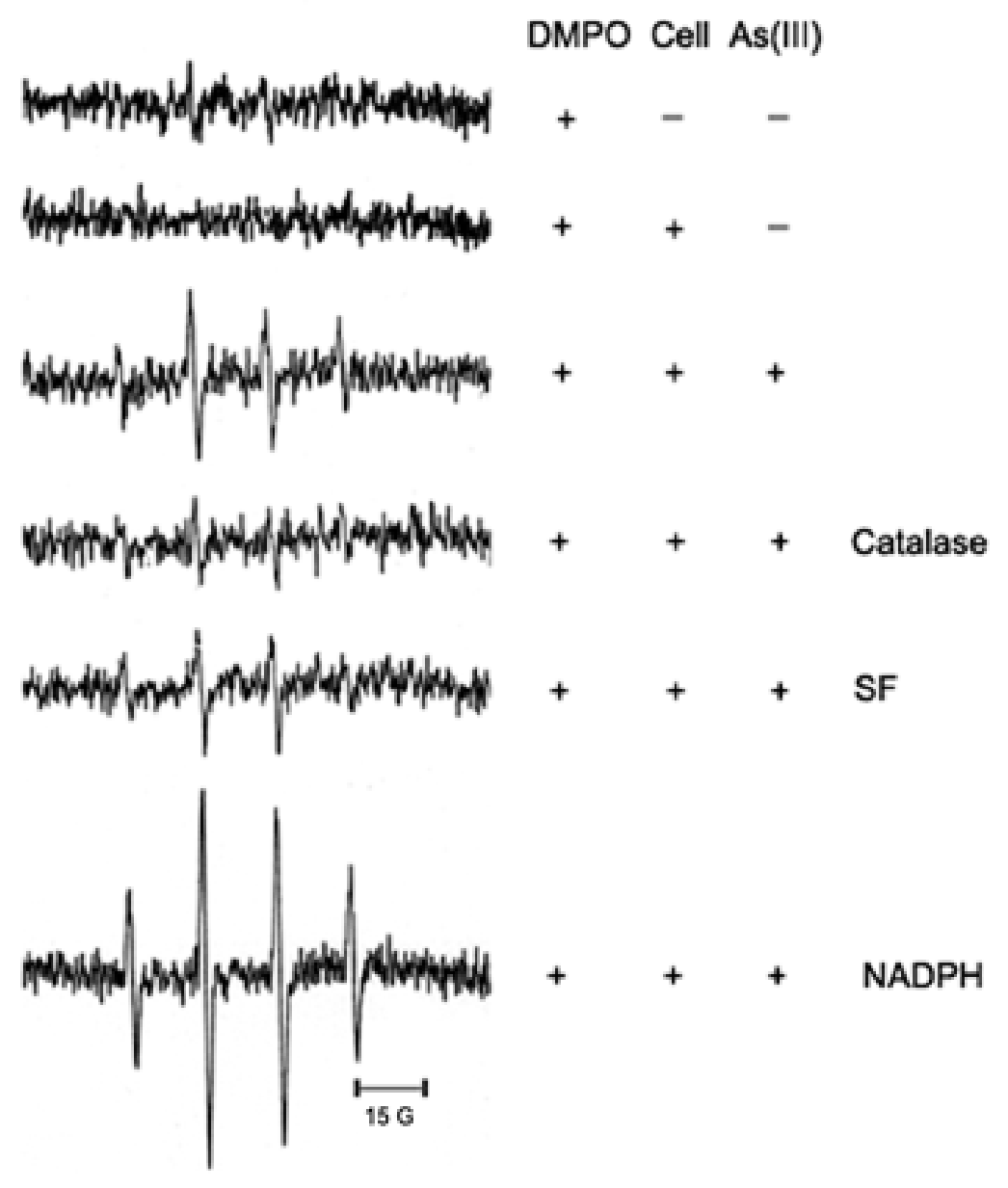

Figure 11. ESR spectra generated by DMPO/ ${ }^{\circ} \mathrm{OH}$ adducts obtained from BEAS-2B cells treated with As. BEAS-2B cells $\left(1 \times 10^{6}\right)$ were incubated with $200 \mathrm{mM}$ of DMPO, and $100 \mu \mathrm{M}$ of As for $10 \mathrm{~min}$ at $37^{\circ} \mathrm{C}$ with or without other reagents. The spectra were integrated by 3 scans. The spectrometer settings were: receiver gain, $6.32 \times 10^{4}$; time constant, $40.960 \mathrm{~ms}$; modulation amplitude, $1.0 \mathrm{G}$; scan time, $41.943 \mathrm{~s}$; magnetic field, $3490 \pm 50 G$. The concentrations of the enzymes and reagent used were: catalase, 2,000 units/ml; sodium formate (SF), $500 \mathrm{mM}$; NADPH, 5mM. 

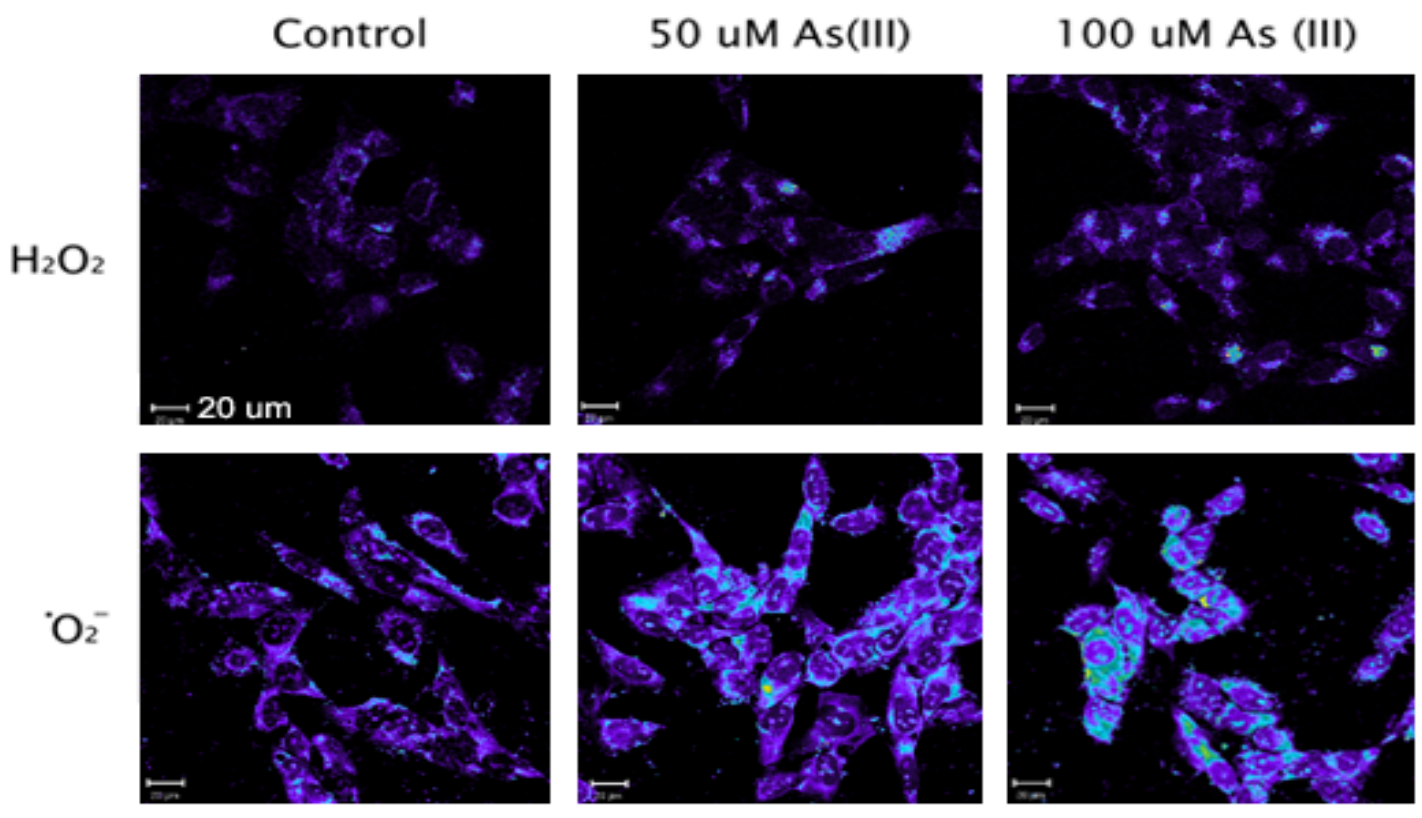

Figure 12. Detection of intracellular $\mathrm{H}_{2} \mathrm{O}_{2}$ and ${ }^{\circ} \mathrm{O}_{2}{ }^{-}$generation by exposure to $\mathrm{As}$ using confocal microscopy. BEAS-2B cells $\left(1 \times 10^{6}\right)$ were exposed with either 50 or $100 \mu \mathrm{M}$ of $\mathrm{As}$ in the presence of $\mathrm{H}_{2}$ DCFDA $(25 \mu \mathrm{M})$ or dihydroethidium $(10 \mu \mathrm{M})$ for $1 \mathrm{hr}$. The cells were washed with PBS, fixed with $10 \%$ buffered formalin for $10 \mathrm{~min}$, and mounted on glass slides. The images were captured with a laser scanning confocal microscope. The bright green, yellow and red areas in the cells represent oxidized DCFHDA and dihydroethidium indicating the intracellular generation and localization of $\mathrm{H}_{2} \mathrm{O}_{2}$ and ${ }^{\circ} \mathrm{O}_{2}^{-}$in BEAS-2B cells. 


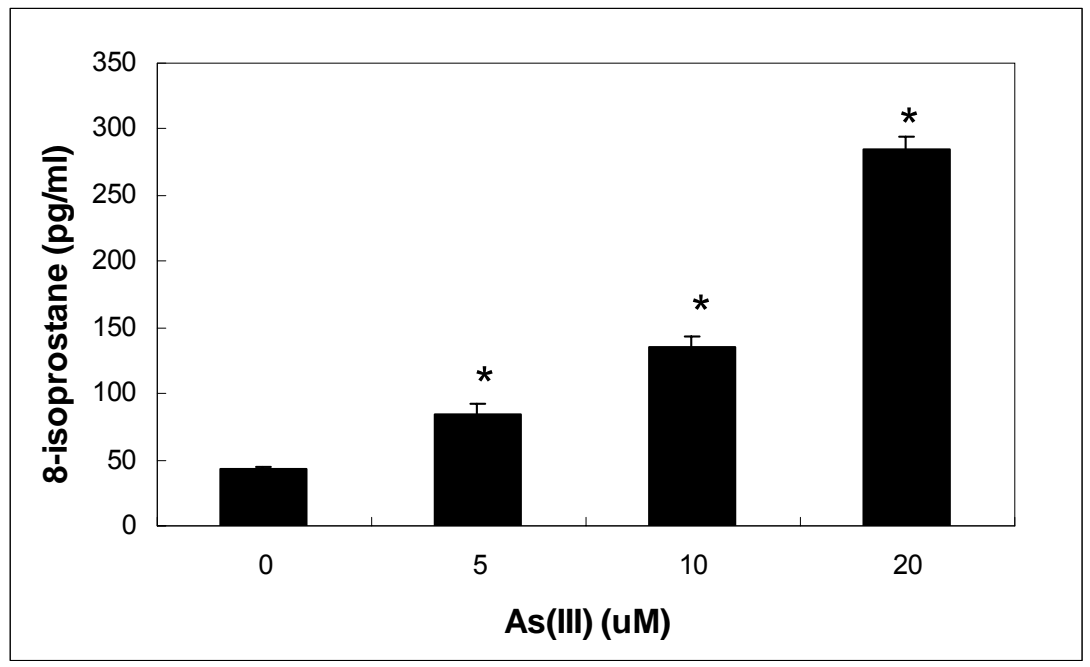

Figure 13. Lipid peroxidation detection by 8-isoprostane ELISA method. Cells were exposed to As for various concentrations $(0-20 \mu \mathrm{M})$ for $24 \mathrm{hr}$ in the 6-well plate with $1 \mathrm{ml}$ culture medium. Immediately after exposure, the medium was directly used for 8isoprostane generation according to the manufacturer's protocol. The optical density was measured at $410 \mathrm{~nm}$, using a microplate spectrophotometer, and values presented represent the mean \pm SE of six assay wells from two independent experiments. *Indicates a significant increase of 8-isoprostane generation from control $(p<0.05)$. 


\section{DISCUSSION}

It is well established that exposure to trivalent and pentavalent arsenic through occupational and environmental sources causes many diseases, including cancer of the lung, skin, liver, kidney and bladder (2). Although exposure to arsenic through inhalation is only one of the routes of exposure, the lung is one of the main targets for toxicity of arsenic. The toxic mechanisms of interactions for arsenic include, but are not limited to, oxidative stress, mutation, gene amplification, DNA methylation, inhibition of DNA repair, uncoupling of oxidative phosphorylation or by combination with thiol groups on the active sites of enzymes and cellular proteins $(3,4)$. Also, it is proposed that arsenic generates free radicals, such as hydrogen peroxide, hydroxyl radical, nitric oxide, and superoxide anion, and all of these reactive species are known to be involved in the stress response induced by arsenic (5).

Heat shock proteins are known to be highly conserved and ubiquitous molecules found in prokaryotic and eukaryotic cells throughout the evolution. They provide a defense and a mechanism for protection of cells in adverse conditions. They have a wide range of housekeeping and cytoprotective roles and are released into the extracellular milieu in adverse conditions, upon injury to cells, or during necrosis. The generation of heat shock proteins is usually transient except under prolonged and sustained damaging conditions. Because homeostasis of heat shock proteins is important for intracellular functions, synthesis is regulated at the expression level through the repression of heat shock gene (6). However, a growing number of reports suggest that, ROS and RNS are involved in the regulation Hsp 70, which may be through the activation of the JAK/STAT pathway (7). In this regard, heavy metals have the potential to generate hydroxyl radicals through a Fenton-like reaction, which may induce oxidative stress resulting in the upregulation of heat shock protein $(8,9,10)$. 
In the present study, investigations were undertaken to explore the effects of trivalent arsenic $\left(\mathrm{AsCl}_{3}\right)$ on $\mathrm{Hsp} 70$ protein expression and the cellular and molecular mechanisms involved. The aim of this study was to explore whether Hsp70 is a sensitive biomarker for arsenic-induced cellular stress or perturbations and to determine the time course of this response to injury. The results demonstrate that exposure of trivalent arsenic to the human bronchial epithelial cell line, BEAS-2B, induces a significant expression of Hsp70 protein and mRNA in a time- and dose-dependent manner. Hsp70 protein and its isoforms were highly expressed in a relatively short time (after a $6 \mathrm{hr}$ exposure) and the protein accumulation rapidly increased during a $12 \mathrm{hr}$ recovery period following exposure. This implies that $\mathrm{Hsp} 70$ and its isoform Hsp70C are potential biomarkers for monitoring cellular damages induced by arsenic with other markers of oxidative injury may provide an excellent finger-print for the early events in arsenic-induced lung injury. The augmented generation of ROS appears to have a profound influence in the induction of heat shock proteins. This is also supported by the direct involvement of ROS in the induction of heat shock proteins and the protective roles of antioxidant enzymes during heat-induced stress in yeast cells (11).

There are at least three highly homologous Hsp70 genes. They are Hsp70A, Hsp70B and Hsp70C (12). These three isoforms are believed to be translated to yield a single Hsp70 protein. In this study, we investigated the differential expression of these three isoforms. Hsp70A and Hsp70B, and Hsp70C mRNA were over-expressed after a $6 \mathrm{hr}$ exposure to arsenic with the expression decreasing during the $12 \mathrm{hr}$ recovery period. This implies that Hsp70 mRNA expression is largely dependent on the transcriptional regulation of the early toxic effect of As exposure, but the protein expression was probably regulated at the translational level in the later recovery stage of cells. Also, it is assumed that the accumulation of Hsp70 protein remained upregulated until the protein turnover gained a faster rate than the synthesis of new protein. 
As stated earlier, arsenic is a well known ROS inducer, and ROS are powerful inducers of heat shock proteins. In this context, investigations were undertaken to study the relationship between the Hsp70 protein expression and the production of ROS and oxidative damage. The Hsp70 protein expression was decreased when the BEAS-2B cells were co-exposed to arsenic and catalase, a $\mathrm{H}_{2} \mathrm{O}_{2}$-scavenging enzyme, and $\mathrm{N}$ acetylcysteine (NAC), a thiol-containing general antioxidant. The results of these investigations indicate that $\mathrm{H}_{2} \mathrm{O}_{2}$ might be an important mediator of As-induced stress protein expression. Compared to catalase, NAC showed a more powerful inhibitory effect on heat shock protein expression, indicating potential binding of As with thiol groups on the active sites of enzymes or cellular proteins. Superoxide dismutase, involved in the conversion of ${ }^{\circ} \mathrm{O}_{2}^{-}$to $\mathrm{H}_{2} \mathrm{O}_{2}$, and sodium formate, a ${ }^{\circ} \mathrm{OH}$ scavenger, had little effect on the induction of Hsp70 protein. The present study shows that As is also able to generate ROS inside of cells. The lipid peroxidation assay showed a significant increase of 8-isoprostane in the cells exposed to As, suggesting oxidative stress in response to As exposure. As-mediated ROS generation was further confirmed by fluorescence staining of As-exposed cells and ESR spin trapping studies. Both ${ }^{\circ} \mathrm{O}_{2}{ }^{-}$and $\mathrm{H}_{2} \mathrm{O}_{2}$ were highly increased in As-exposed cells as measured by confocal microscopy. By ESR spectroscopy and spin trapping ${ }^{\circ} \mathrm{OH}$ generation was confirmed as the final end product of As exposure to BEAS-2B cells. However, reactive nitrogen species were detected in As-exposed BEAS-2B cells (data not shown).

Findings presented here suggest that Hsp70 is a sensitive biomarker of cellular stress or perturbations induced by arsenic. ROS appears to play a crucial role in arsenic-induced Hsp70 expression. It is possible that monitoring $\mathrm{Hsp} 70$ and oxidative stress biomarkers in the serum of workers exposed to arsenic may prove to be a valuable tool to monitor arsenic exposure/response. 


\section{REFERENCES}

1. Kim D, Somji S, Garrett SH, Sens MA, Shukla D, Sens DA. Expression of hsp 27, hsp 60, hsc 70, and hsp 70 by immortalized human proximal tubule cells (HK-2) following exposure to heat shock, sodium arsenite, or cadmium chloride. J Toxicol Environ Health $10:: 475-93,2001$.

2. Chen F, Lu Y, Zhang Z, Vallyathan V, Ding M, Castranova V, Shi X. Opposite effects of NF-kB and c-Jun N-terminal kinase on p53-independent GADD45 induction by arsenic. J Biol Chem 276: 11414-11419, 2001.

3. Kitchin KT. Recent advances in arsenic carcinogenesis: modes of action, animal model systems, and methylated arsenic metabolites. Toxicol Appl Pharmacol 172: 249-261, 2001.

4. Chattopadhyay S, Bhaumik S, Nag Chaudhury A, Das Gupta S. Arsenic induced changes in growth development and apoptosis in neonatal and adult brain cells in vivo and in tissue culture. Toxicol Lett 128:73-84, 2002.

5. Del Razo LM, Quintanilla-Vega B, Brambila-Colombres E, Calderon-Aranda ES, Manno M, Albores A. Stress proteins induced by arsenic. Toxicol Appl Pharmacol 177:132-48, 2001.

6. Shi Y, Mosser DD, Morimoto RI. Molecular chaperones as HSF1-specific transcriptional repressors. Genes Dev 12: 654-666, 1998.

7. Madamanchi NR, Li S, Patterson C, Runge MS. Reactive oxygen species regulate heat-shock protein 70 via the JAK/STAT pathway. Arterioscler Thromb Vasc Biol 21: 321-326, 2001.

8. Ciocca DR, Oesterreich S, Chamness GC, McGuire WL, Fuqua SAW. Biological and clinical implication of heat shock protein 27000 (Hsp27): a review. J Nat Cancer Inst 85(19):1558-1570, 1993. 
9. Shi X, Chiu A, Chen CT, Halliwell B, Castranova V, Vallyathan V. Reduction of chromium(VI) and its relationship to carcinogenesis. J Toxicol Environ Health B Crit Rev 2: 87-104, 1999.

10. Kamp DW, Vallyathan V. Influence of mineral dust surface characteristics and generation of reactive species. In: Oxygen/Nitrogen Radicals Lung Injury and Disease, 2004, Eds. Vallyathan V, Castranova V, Shi X, Marcel Dekker, New York, NY, pp 139-157.

11. Davidson JF, Whyte B, Bissinger PH, Schiestl RH. Oxidative stress is involved in heat-induced cell death in Saccharomyces cerevisiae. Proc Natl Acad Sci U.S.A.93: 5116-5121, 1996.

12. Leung TK, Rajendran MY, Monfries C, Hall C, Lim L. The human heat-shock protein family. Expression of a novel heat-inducible HSP70 (HSP70B') and isolation of its cDNA and genomic DNA. Biochem J 267:125-32, 1990. 


\section{CHAPTER III}

HSP70 EXPRESSION AND REACTIVE OXYGEN SPECIES GENERATION IN HUMAN

BRONCHIAL CELL LINE, BEAS-2B, CAUSED BY EXPOSURE TO CADMIUM 


\section{INTRODUCTION}

The principle aim of studies presented in this chapter was to analyze how BEAS2B cells respond to toxic metal, cadmium $\left(\mathrm{CdCl}_{2}\right)$. It was shown in the Chapter I that $\mathrm{Cd}$ is toxic to BEAS-2B cells leading to apoptosis and cell death. Cd induced ROS generation, and Hsp70 protein expression was upregulated at the level of transcription. In this chapter, the relationship of Cd exposure and the levels of Hsp70 expression were further investigated in correlation with ROS generation. Also, from the results obtained it is reasonable to propose that Hsp could be used as a sensitive biomarker for studies on human serum of $\mathrm{Cd}$ exposure in occupational and environmental settings. 


\section{RESULTS}

Cytotoxicity of Cd to BEAS-2B Cells

Cd is believed to induce cell damage and other molecular changes including apoptosis and necrosis. To determine the cytotoxic effects and to select optimal concentrations without causing significant cytotoxicity to $\mathrm{Cd}$ in human bronchial epithelial cell line BEAS-2B, studies were performed using a MTT assay with different concentrations of Cd and time periods exposure (Fig. 14). Cytotoxicity resulting from Cd increased in a dose and time dependent manner during a 3 day exposure period. On day one, the survival rate decreased significantly to 64,44 and $7 \%$ at 10,20 , and $50 \mu \mathrm{M}$ concentrations of $\mathrm{Cd}$, respectively. The survival rate decreased further to 29 , and $28 \%$ on day two and three, respectively in $10 \mu \mathrm{M}$ concentration of $\mathrm{Cd}$; however almost all cells were killed in 20 and $50 \mu \mathrm{M}$ concentrations of $\mathrm{Cd}$ compared to control. The analysis of cytotoxicity data indicated a decrease in cell viability beginning before $24 \mathrm{hr}$ exposure to Cd. Cytotoxicity continued to increase substantially at day two and three. Therefore, this dose and time-dependent cytotoxicity was taken into consideration in all further studies.

\section{Expression of Hsp70 Protein is Increased in a Dose-dependent Manner by Cd Exposure}

The expression of Hsp70 protein was determined after exposing BEAS-2B cells to $\mathrm{Cd}$ for 3 and $6 \mathrm{hr}$, followed by recovery periods (0-24 hr). Western blot analysis showed that Hsp70 protein expression increased approximately 1.4, 2.0 and 3.5-fold at 5, 10 and $20 \mu \mathrm{M}$ Cd concentrations, respectively, following a $3 \mathrm{hr}$ exposure and a $12 \mathrm{hr}$ recovery period (Fig. 15, A). Hsp70 was also increased approximately 2.9, 5.0 and 6.0fold at 5, 10 and $20 \mu \mathrm{M}$ concentrations of Cd, respectively, following a $6 \mathrm{hr}$ exposure and $12 \mathrm{hr}$ recovery period (Fig. 15, B). The maximum accumulation of Hsp70 was observed 
at $20 \mu \mathrm{M} \mathrm{Cd}$ exposure. To determine the Hsp70 protein accumulation for longer recovery periods, cells were recovered for extended times (0-96 hr) after $20 \mathrm{uM} \mathrm{Cd}$ exposure for $3 \mathrm{hr}$ (Fig 15, C). The maximum accumulation was achieved at a 12-24 hr recovery period followed by decrease, but the accumulation was still elevated at the 96 hr recovery time compared to control. To further confirm, the Hsp70 ELISA assay was performed. The quantity of Hsp70 expressed were dose dependent with $\mathrm{Cd}$ exposure (Fig. 16). In the Hsp70 ELISA assay, the expression of Hsp70 was most prominent in the cells exposed to $\mathrm{Cd}$ for 3 and $6 \mathrm{hr}$ with a $12 \mathrm{hr}$ recovery period. Hsp70 protein expression was increased approximately 3.1, 7.2 and 9.5-fold at 5, 10 and $20 \mathrm{uM} \mathrm{Cd}$ concentrations, respectively, in a $3 \mathrm{hr}$ exposure and a $12 \mathrm{hr}$ recovery period (Fig. 16). In a $6 \mathrm{hr}$ exposure and a $12 \mathrm{hr}$ recovery time, the expression was increased 8.0, 9.5 and 9.6-fold at 5, 10 and $20 \mu \mathrm{M} \mathrm{Cd}$ concentrations, respectively (Fig. 16).

\section{Hsp70 mRNA Expression in BEAS-2B Cells Exposed to Cd}

To investigate the effects of $\mathrm{Cd}$ exposure on the expression of three Hsp mRNA isoforms in BEAS-2B cell, we analyzed the expression of three isoforms of mRNA after a $6 \mathrm{hr}$ exposure and a recovery period of 0-24 hr. The results for the expression of mRNA generated for the Hsp70A, B and C genes are presented from a typical agarose gel experiment (Fig. 17, D). Graphic illustration of the mean values from three independent experiments on the expression of these Hsp genes, compared to mRNA from the G3PDH housekeeping gene, is presented in Figure 17, A, B and C. The analysis showed that each isoform of Hsp70 genes had a differential expression pattern when the cells were exposed to $\mathrm{Cd}$. Hsp70A mRNA expression was not significantly changed in all $\mathrm{Cd}$ concentrations tested. However, there was a non-significant overexpression during a 0-12 hr of recovery periods in all the Cd concentrations (Fig. 17, A). During the recovery periods of $18-24 \mathrm{hr}$, the Hsp70A mRNA expression decreased toward the 
control level. Hsp70B mRNA expression was increased approximately 7.5, 22.8, and 19-fold at 5, 10 and $20 \mu \mathrm{M} \mathrm{Cd}$ concentrations, respectively, after a zero hr recovery time (Fig. 17, B). At 12-24 hours of recovery, the Hsp70B mRNA expression returned to the control level in $5 \mu \mathrm{M}$ concentration of Cd; however the expression was still higher in 10 $\mu \mathrm{M}$ and $20 \mu \mathrm{M}$ of $\mathrm{Cd}$ exposure. The expression pattern of Hsp70C mRNA was similar to that of Hsp70B mRNA. The Hsp70C mRNA expression was increased approximately 1.6, 1.5, and 1.6-fold at 5, 10 and $20 \mu \mathrm{M}$ Cd concentrations, respectively, after a zero $\mathrm{hr}$ recovery period (Fig. 17, C). Hsp70C mRNA returned to the control level during 18-24 hr of recovery time at 5 , and $10 \mu \mathrm{M} \mathrm{Cd}$ but remained elevated during the recovery period in $20 \mu \mathrm{M} \mathrm{Cd}$ exposed cells. Taken together, it was apparent that the expression of mRNA of Hsp70B and Hsp70C genes are rapidly increased and are responsible for overexpression of $\mathrm{Hsp} 70$ protein in response to $\mathrm{Cd}$ exposure. Hsp70B was the most sensitive in response to Cd exposure.

Effect of Antioxidants on Cd-induced Hsp70 Protein Expression by Western Blotting

Figure 18 shows the effects of antioxidants on Cd-induced Hsp70 expression. Catalase, a $\mathrm{H}_{2} \mathrm{O}_{2}$-scavenging enzyme, $\mathrm{SOD}$, a ${ }^{\circ} \mathrm{O}_{2}^{-}$radical scavenger that generates $\mathrm{H}_{2} \mathrm{O}_{2}$, and $\mathrm{SF}$, an ${ }^{\circ} \mathrm{OH}$ radical scavenger had non-significant effect $(<10 \%)$ on the inhibition of Hsp70 protein expression. N-acetylcysteine, a thiol-containing general antioxidant, significantly inhibited the induction of Hsp70 protein by 2-fold. These results suggest that oxidative stresses such as cell's thiol status appear to play a key role in Cdinduced Hsp70 protein expression.

\section{Generation of Hydroxyl Radicals by Cd}

To test whether Cd induces ROS generation, BEAS-2B cells were exposed to various concentrations of $\mathrm{Cd}$ for $10 \mathrm{~min}$ in the presence of DMPO and phosphate buffer 
at $37^{\circ} \mathrm{C}$ with and without free radical scavengers. ESR spectra, recorded $10 \mathrm{~min}$ after the initiation of reaction in phosphate buffer containing $200 \mathrm{mM}$ DMPO and Cd, showed a typical 1:2:2:1 quartet with hyperfine splittings of $a_{H}=a_{N}=14.9 \mathrm{G}$. Based on these splitting constants of hydrogen and nitrogen, the signal was assigned to a DMPO/ $\mathrm{OH}$ adduct, demonstrating the generation of ${ }^{\circ} \mathrm{OH}$ radicals. Figure 19 shows the ESR signal generated. Addition of either catalase, a $\mathrm{H}_{2} \mathrm{O}_{2}$ scavenger, or sodium formate, ${ }^{\circ} \mathrm{OH}$ radical scavenger, inhibited ${ }^{\circ} \mathrm{OH}$ generation substantially. Addition of NADPD, a reducing agent, significantly increased the ${ }^{\circ} \mathrm{OH}$ signal. Control experiments without the addition of cells or $\mathrm{Cd}$ with equivalent volumes of DMPO and phosphate buffer did not develop significant signal intensity.

Detection of Intracellular ROS Generation by Exposure to Cd using Confocal Microscopy Generation of ROS by Cd was further confirmed by confocal microscopy. BEAS2B cells were exposed with $\mathrm{Cd}$ in the presence of $\mathrm{H}_{2}$ DCFDA, a specific fluorescent dye for $\mathrm{H}_{2} \mathrm{O}_{2}$, or dihydroethidium, a specific fluorescent dye for $\mathrm{O}_{2}^{-}$. Images are displayed in pseudocolor where blue indicates areas of low intensity and increasingly high intensity areas are green $<$ yellow $<$ red $<$ white. In the presence of increasing concentrations of Cd the intensity of fluorescence increased compared to control. To document the high intensity gradient levels of $\mathrm{H}_{2} \mathrm{O}_{2}$ and ${ }^{\circ} \mathrm{O}_{2}{ }^{-}$generated cells were exposed to 20 and $40 \mu \mathrm{M}$ of $\mathrm{Cd}$ and results obtained are displayed (Fig. 20). Both $\mathrm{H}_{2} \mathrm{O}_{2}$ and ${ }^{\circ} \mathrm{O}_{2}^{-}$were increased inside of cells in a dose dependent manner. 


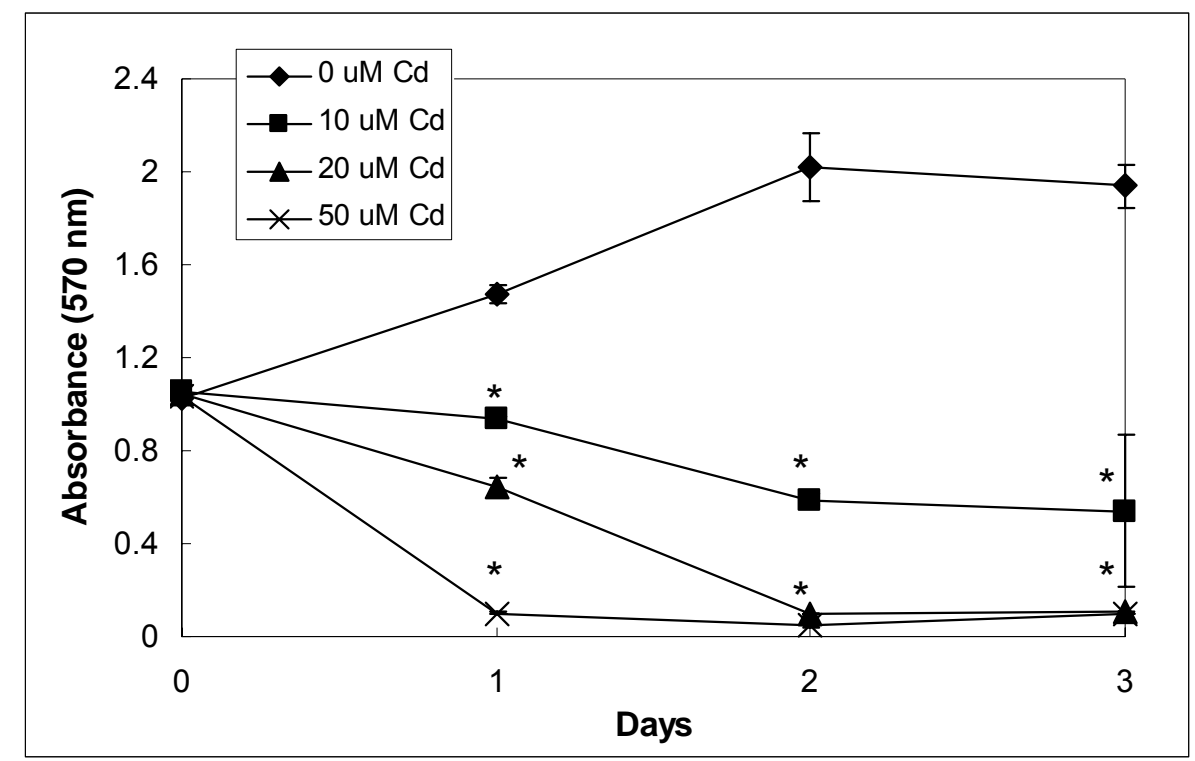

Figure 14. Cytotoxicity of Cd to BEAS-2B cells determined by the MTT assay. BEAS2B cells were seeded in 96 -well plates at $2 \times 10^{4}$ cell/well and incubated for $24 \mathrm{hr}$. The medium was changed, and cells in triplicate were exposed to different $\mathrm{Cd}(0-50 \mu \mathrm{M})$ concentrations for 3 days. The optical density was measured at $570 \mathrm{~nm}$, and values presented represent the mean \pm SE of six assay wells from two independent experiments. *Indicates a significant decrease of cell viability from control $(p<0.05)$. 


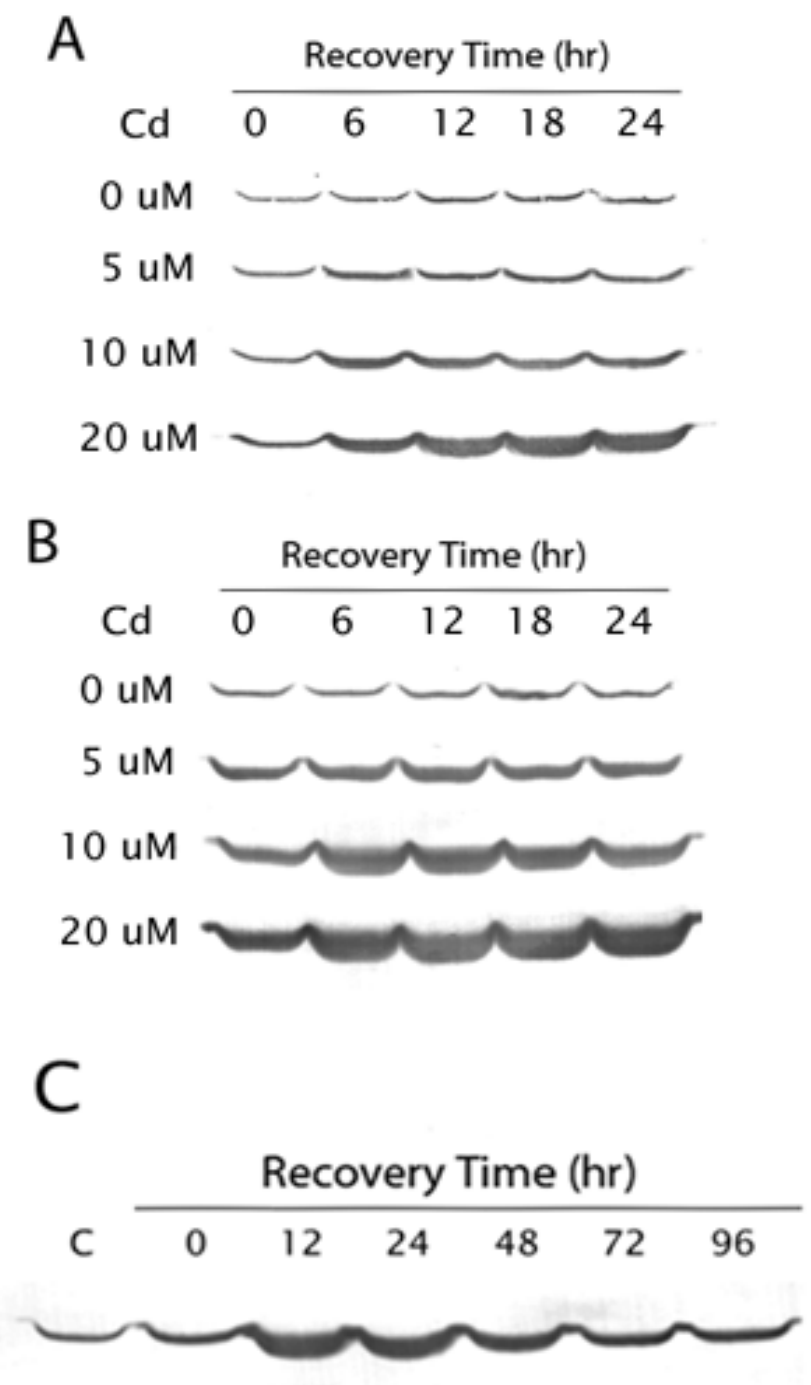

Figure 15. Hsp70 protein detection by Western blotting during recovery periods. BEAS-2B cells were exposed to $\mathrm{Cd}$ for two different times, $3 \mathrm{hr}(\mathrm{A})$ and $6 \mathrm{hr}(\mathrm{B})$, followed by recovery with fresh media for five different time periods (0-24 hr) as indicated. (C) Cells were exposed to $\mathrm{Cd}$ for $3 \mathrm{hr}$ and recovered for $96 \mathrm{hr}$ periods. Cells were harvested and $30 \mu \mathrm{g}$ of total protein samples separated by $10 \%$ SDS-PAGE were transferred onto $0.2 \mu \mathrm{m}$ nitrocellulose membranes. Western blotting was performed with the anti-Hsp70 monoclonal antibody. 


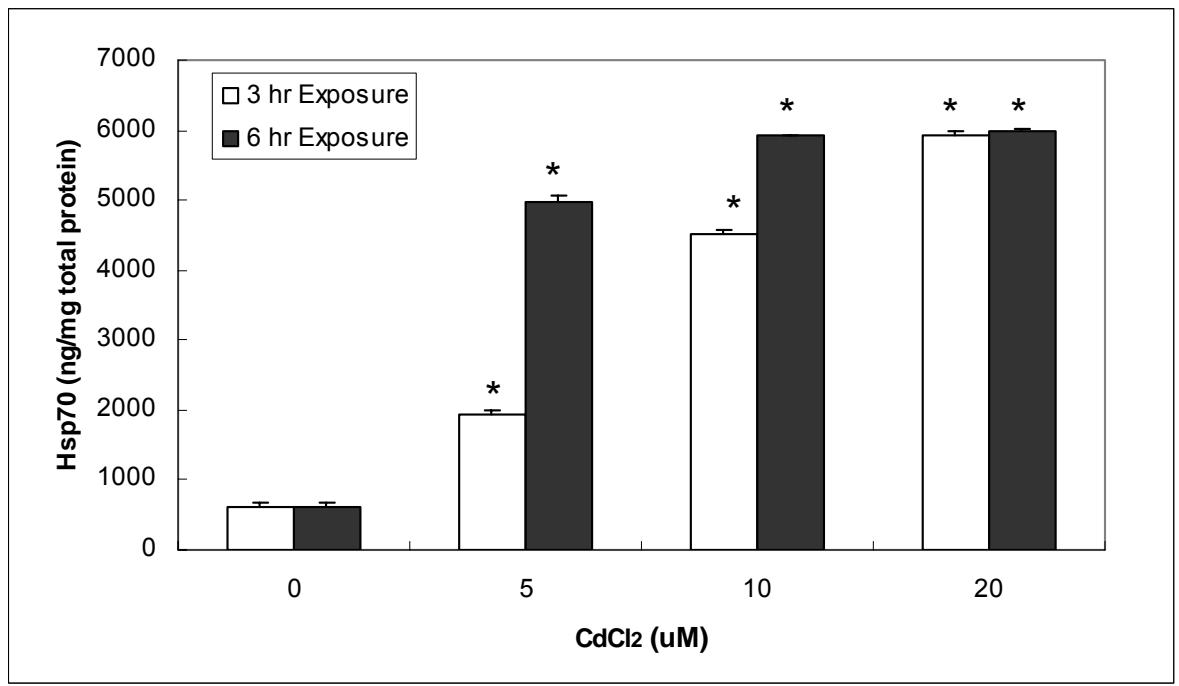

Figure 16. Hsp70 protein detection by ELISA. BEAS-2B cells were exposed to Cd for two different times, $3 \mathrm{hr}$ and $6 \mathrm{hr}$, followed by recovery with fresh media for $12 \mathrm{hr}$. Cells were harvested and the total protein samples $(0.025 \mu \mathrm{g} / \mu \mathrm{l})$ were tested by Hsp70 ELISA kit. The absorbance of samples was measured at $450 \mathrm{~nm}$, using a microplate spectrophotometer. The values of Hsp70 concentrations ( $\mathrm{ng} / \mathrm{mg}$ total protein) of each sample presented represent the mean \pm SE of six assay wells from two independent experiments. *Indicates a significant increase from control $(p<0.05)$. 


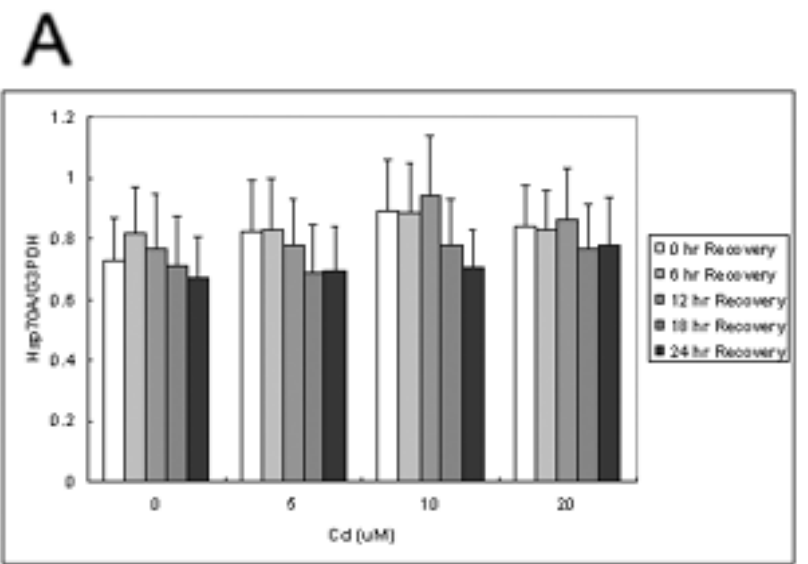

B
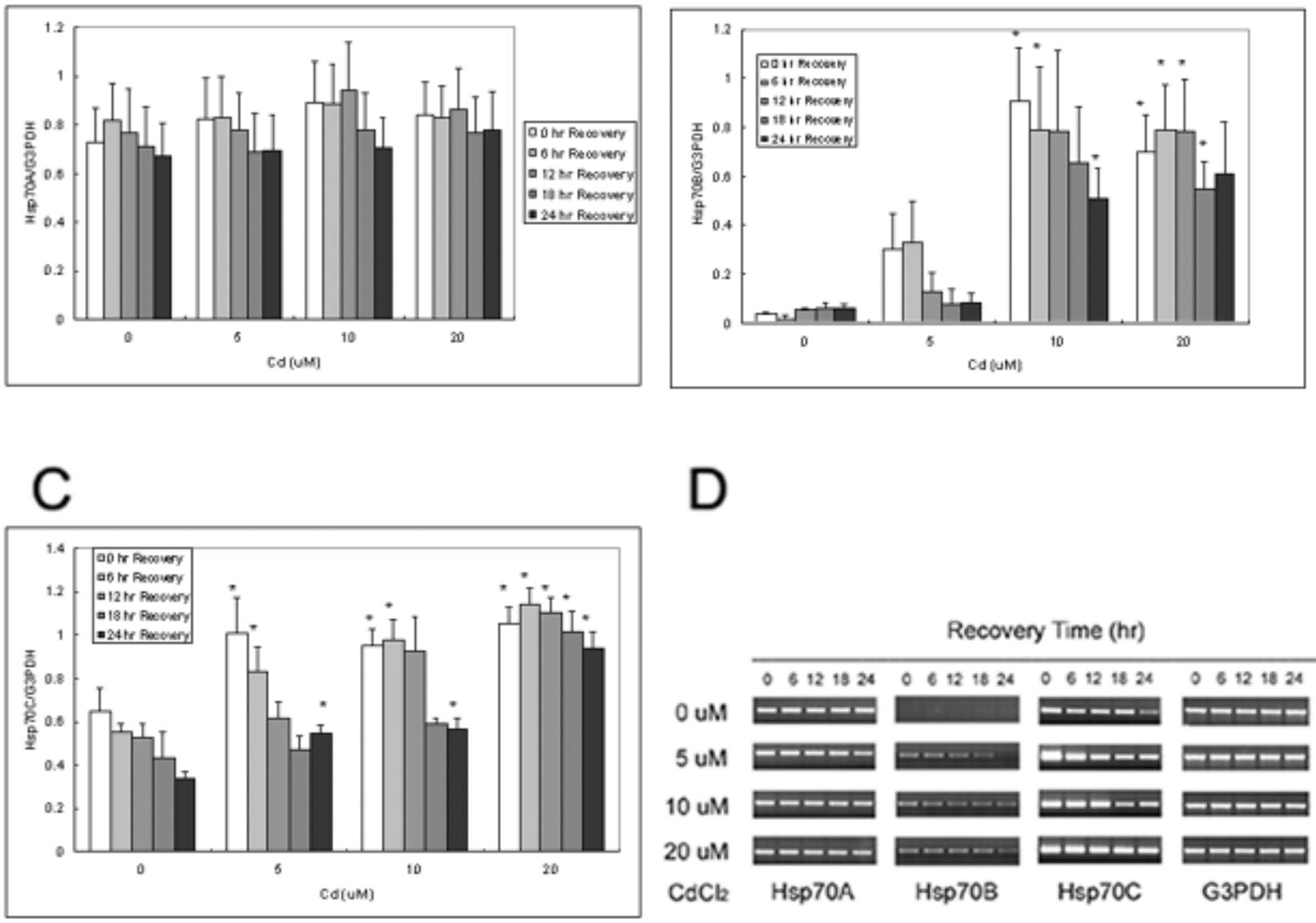

Figure 17. RT-PCR analysis of mRNA from BEAS-2B cells exposed to $C d$. BEAS-2B cells were exposed to $0-20 \mu \mathrm{M}$ Cd for $6 \mathrm{hr}$, followed by a $0-24 \mathrm{hr}$ recovery period. The values of Hsp70A (A), Hsp70B (B), and Hsp70C (C) mRNA expression presented represent mean \pm SE of relative integrated optical density of bands divided by that for the housekeeping gene, G3PDH, from three independent experiments. (D) A representative agarose gel picture from one of the experiments used for data analysis. *Indicates a significant increase from control $(p<0.05)$. 


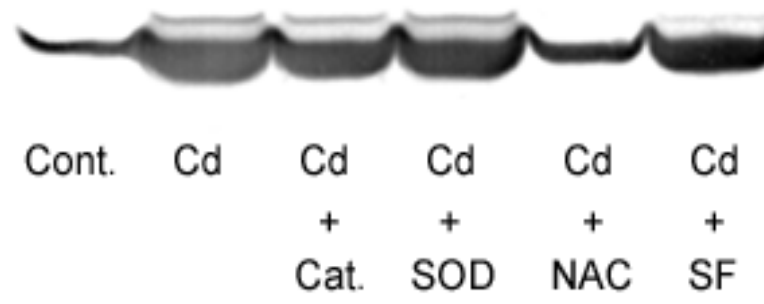

Figure 18. Effect of antioxidants and other reagents on Cd-induced Hsp70 protein expression by Western blotting. BEAS-2B cells were exposed to $20 \mu \mathrm{M} \mathrm{Cd}$ with or without antioxidants for $6 \mathrm{hr}$. Western blotting was performed to test the level of Hsp70 expression. The concentrations of the antioxidants used were: catalase, 2,000 units/ml; superoxide dismutase (SOD), 2,000 units/ml; $N$-acetylcysteine (NAC), 10mM; sodium formate (SF), $50 \mathrm{mM}$. 
DMPO Cell Cd
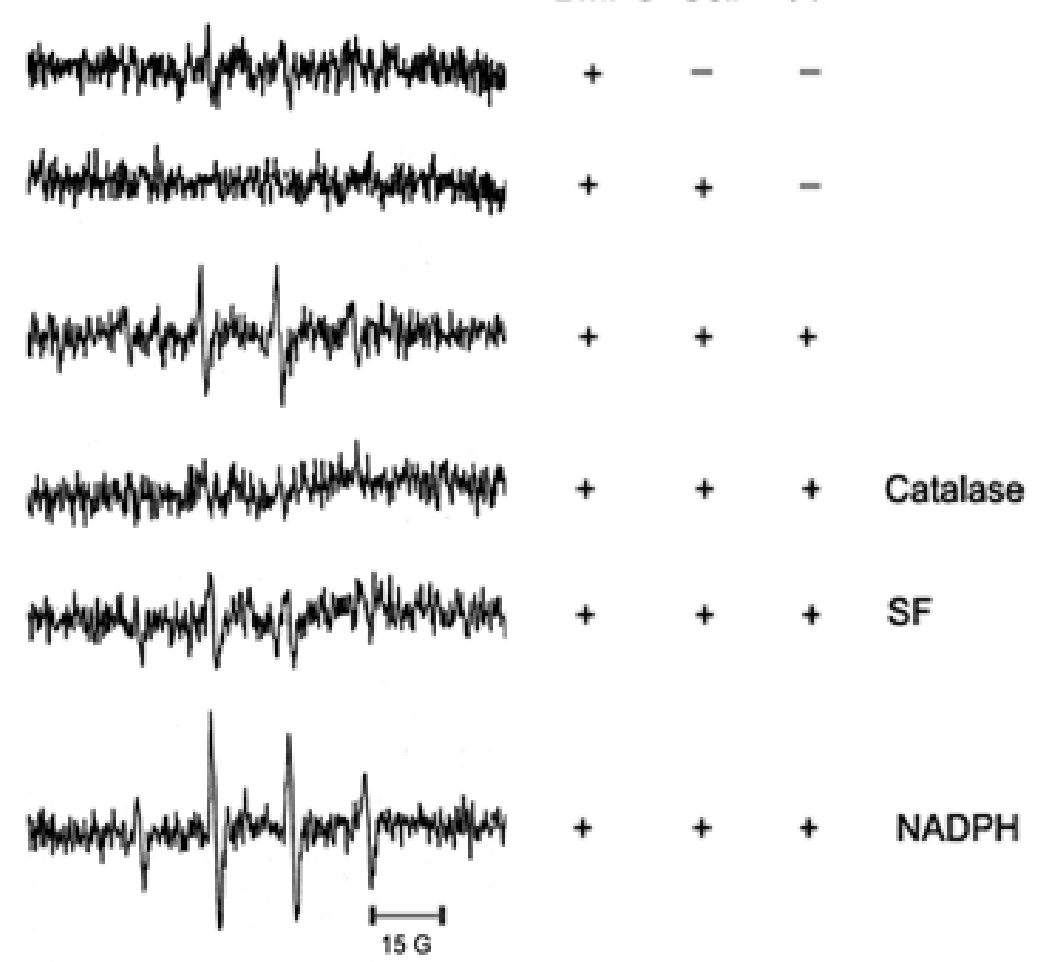

Figure 19. ESR spectra generated by DMPO/OH adducts obtained from BEAS2B cells treated with $C d$. BEAS-2B cells $\left(1 \times 10^{6}\right)$ were incubated with $200 \mathrm{mM}$ of DMPO and $100 \mu \mathrm{M}$ of $\mathrm{Cd}$ for $10 \mathrm{~min}$ at $37{ }^{\circ} \mathrm{C}$ with or without other reagents. The spectra were integrated by 3 scans. The spectrometer settings were: receiver gain, 6.32 X 104; time constant, $40.960 \mathrm{~ms}$; modulation amplitude, $1.0 \mathrm{G}$; scan time, $41.943 \mathrm{~s}$; magnetic field, $3490 \pm 50 \mathrm{G}$. The concentrations of the enzymes and reagent used were: catalase, 2,000 units/ml; sodium formate (SF), $500 \mathrm{mM}$; NADPH, $5 \mathrm{mM}$. 

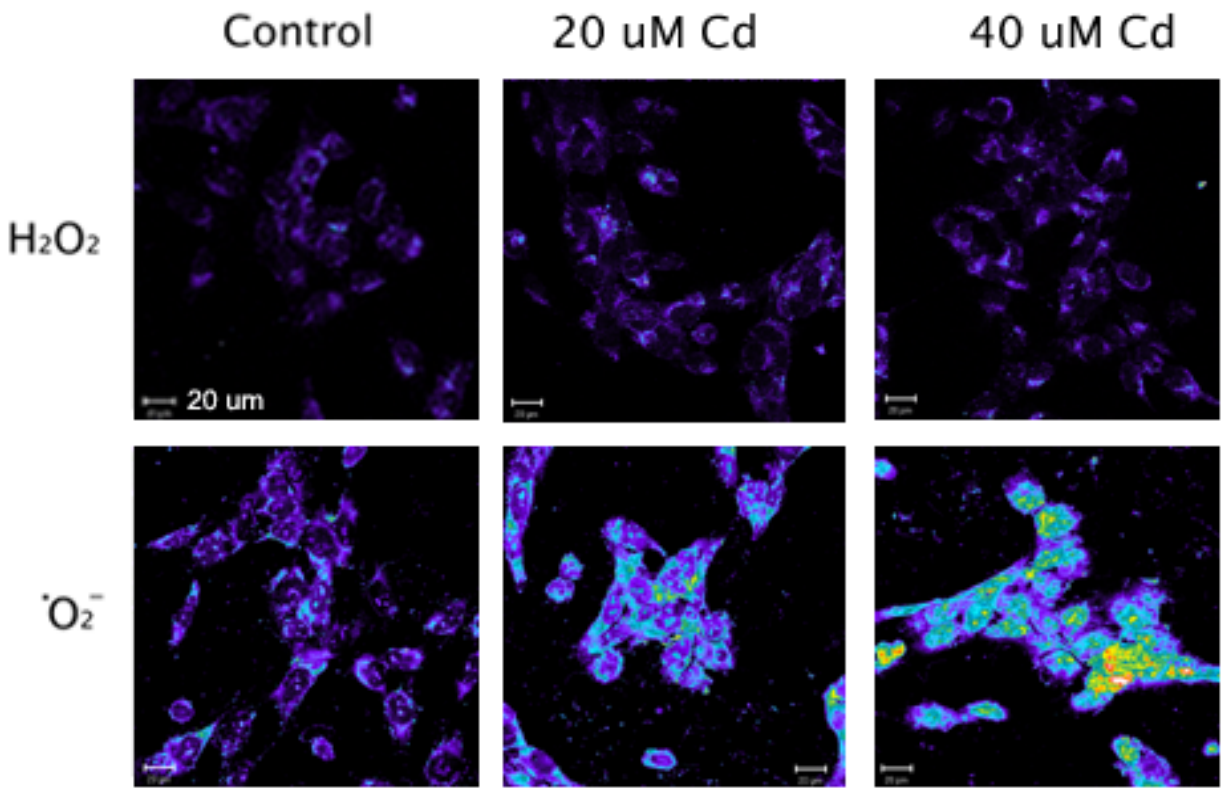

Figure 20. Detection of intracellular $\mathrm{H}_{2} \mathrm{O}_{2}$ and $\mathrm{O}_{2}{ }^{-}$generation by exposure to $\mathrm{Cd}$ using confocal microscopy. BEAS-2B cells $\left(1 \times 10^{6}\right)$ were exposed with either 20 or 40 $\mu \mathrm{M}$ of $\mathrm{Cd}$ in the presence of $\mathrm{H}_{2}$ DCFDA $(25 \mu \mathrm{M})$ or dihydroethidium $(10 \mu \mathrm{M})$ for $1 \mathrm{hr}$. The cells were washed with PBS, fixed with $10 \%$ buffered formalin for $10 \mathrm{~min}$, and mounted on glass slides. The images were captured with a laser scanning confocal microscope. The bright green, yellow and red areas in the cells represent oxidized DCFHDA and dihydroethidium indicating the intracellular generation and localization of $\mathrm{H}_{2} \mathrm{O}_{2}$ and ${ }^{\circ} \mathrm{O}_{2}^{-}$ in BEAS-2B cells. 


\section{DISCUSSION}

It has been known that exposure to cadmium through occupational and environmental sources causes several harmful health effects in humans (1). Cd is used in many different industries and human exposure may cause accumulation in several organs including lung, kidney, and liver $(1,2)$. Lung is one of the main targets of Cdinduced toxicity and cancer is reported to be the major outcome $(3,4)$. In Cd exposed cadmium plant workers an excess of lung cancer was reported with two or more years of exposure history documenting a clear association between $\mathrm{Cd}$ exposure and lung cancer. The toxic mechanisms of $\mathrm{Cd}$ are not fully understood, but its toxicity is prolonged by long half life of $\mathrm{Cd}(5)$. Cd is called a redox-inactive metal that does not catalyze Fenton-type reaction $(6,7)$. However, the toxic mechanisms of Cd include oxidative stress, lipid peroxidation, altered antioxidant balance, and depletion of GSH levels $(6,8)$. It is proposed that $\mathrm{Cd}$ generates ROS, such as hydrogen peroxide, hydroxyl radical, nitric oxide, or superoxide anion, by depletion of cellular GSH, and antioxidants (9).

Heat shock proteins are known to be highly conserved and ubiquitous molecules providing a defensive mechanism for protection of cells from conditions of stress. As stated earlier in Chapter II, Hsps have a wide range of housekeeping and cytoprotective roles and are released into the extracellular milieu in adverse conditions, upon injury to cells, or during necrosis. Hsp70 expression is actively enhanced in the cells under adverse conditions. These adverse conditions include a variety of physical, physiological, and pathological conditions $(10,11)$. ROS were believed to be involved in the upregulation of Hsp70. Cd has the potential to generate ROS through depletion of GSH and protein-bound $\mathrm{SH}$ groups which may induce oxidative stress resulting in the upregulation of heat shock protein $(7,12,13)$. 
In this study, we investigated the effects of cadmium chloride $\left(\mathrm{CdCl}_{2}\right)$ on $\mathrm{Hsp} 70$ protein expression and the cellular and molecular mechanisms involved. The goal of this study was to explore whether Hsp70 is a sensitive biomarker for cadmium-induced cellular stress or perturbations and to determine the time course of this response to injury. The results demonstrate that exposure of $\mathrm{Cd}$ to the human bronchial epithelial cell line, BEAS-2B, induces a significant expression of Hsp70 protein and mRNA in a time- and dose-dependent manner. Hsp70 protein and its genes were highly expressed in a relatively short time (after a $3 \mathrm{hr}$ exposure) and the protein accumulation rapidly increased during a $24 \mathrm{hr}$ recovery period following exposure. This implies that Hsp70 protein and its Hsp70B gene expression may be potential biomarkers for monitoring cellular damages induced by $\mathrm{Cd}$. The increased generation of ROS appears to be an important stimulator in the induction of Hsp70 at least in part.

Expression of the three highly homologous Hsp70 genes (Hsp70A, Hsp70B and Hsp70C) was investigated. Hsp70B, and Hsp70C mRNA was over-expressed after a 6 hr exposure to Cd, while Hsp70A expression was not changed. This implies that Hsp70 expression is largely dependent on the transcriptional regulation in the early stages of Cd-induced toxicity. It was further supported by the experiments using actinomycin $D$ as described in Chapter I.

However, the Hsp70 protein overexpression was probably regulated at the translational level in the later recovery stage of cells because Hsp70 protein level remained higher during $96 \mathrm{hr}$ recovery periods despite of no new synthesis of mRNA. It is also assumed that the accumulation of Hsp70 protein remained upregulated due to a slower protein turnover rate.

Cadmium is able to induce oxidative stress which is a powerful inducer of heat shock proteins. In this context, we investigated the relationship between the Hsp70 protein expression and the production of ROS and oxidative damage. The Hsp70 
protein expression was decreased when the BEAS-2B cells were exposed with $N$ acetylcysteine (NAC), a thiol-containing general antioxidant. These results indicate that binding of $\mathrm{Cd}$ with thiol groups of the active sites of enzymes or cellular proteins promotes Hsp70 expression. Catalase, a $\mathrm{H}_{2} \mathrm{O}_{2}$ scavenging enzyme, superoxide dismutase, involving the conversion of ${ }^{\circ} \mathrm{O}_{2}{ }^{-}$to $\mathrm{H}_{2} \mathrm{O}_{2}$, and sodium formate, ${ }^{\circ} \mathrm{OH}$ scavenger, had little effect $(<10 \%$ each) on the induction of Hsp70 protein. These results are parallel with a weak generation of ROS in ESR studies. Also, these results suggest that Cd-induced Hsp70 expression is mainly through denaturation of thiol-containing proteins that is an inducer of heat shock factor instead of through generation of ROS and influencing its expression.

The lipid peroxidation assay did not show a significant increase in cultured human lung cells while other studies on animals showed increased lipid peroxidation by exposure to $\mathrm{Cd}$ (14). Although it is minimal, this study shows that $\mathrm{Cd}$ is capable of generating ROS inside of cells by fluorescence staining of Cd-exposed cells. Both ${ }^{\circ} \mathrm{O}_{2}^{-}$ and $\mathrm{H}_{2} \mathrm{O}_{2}$ were increased in $\mathrm{Cd}$-exposed cells as measured by confocal microscopy. By ESR spectroscopy and spin trapping ${ }^{\circ} \mathrm{OH}$ generation was confirmed as the final end product of Cd exposure to BEAS-2B cells.

The findings reported in these studies suggest that Hsp70 is a sensitive biomarker of cellular stress or perturbations induced by cadmium. Oxidative damage by depletion of thiol-containing antioxidants and ROS generation appears to play a role in Cd-induced Hsp70 expression. 


\section{REFERENCES}

1. Jarup L. Hazards of heavy metal contamination. Br Med Bull. 2003;68:167-82.

2. Gerhardsson L, Englyst V, Lundstrom NG, Sandberg S, Nordberg G. Cadmium, copper and zinc in tissues of deceased copper smelter workers. J Trace Elem Med Biol. 2002;16(4):261-6.

3. International Agency for Research on Cancer, 1993. Beryllium, cadmium, mercury, and exposure in the glass manufacturing industry. In: International Agency for Research on Cancer Monographs on the Evaluation of Carcinogenesis Risks to Humans, vol. 58. IARC Scientific Publications, Lyon, pp. 119-237.

4. National Toxicology Program, 2000. Ninth report on carcinogens. National Toxicology Program, Research Triangle Park, NC, USA.

5. Waalkes MP. Cadmium carcinogenesis. Mutat Res. 2003 Dec 10;533(1-2):107-20.

6. Ercal N, Gurer-Orhan H, Aykin-Burns N. Toxic metals and oxidative stress part I: mechanisms involved in metal-induced oxidative damage. Curr Top Med Chem. 2001 Dec;1(6):529-39.

7. Stohs SJ, Bagchi D. Oxidative mechanisms in the toxicity of metal ions. Free Radic Biol Med. 1995 Feb;18(2):321-36.

8. Shaikh ZA, Vu TT, Zaman K. Oxidative stress as a mechanism of chronic cadmiuminduced hepatotoxicity and renal toxicity and protection by antioxidants. Toxicol Appl Pharmacol. 1999 Feb 1;154(3):256-63.

9. Waisberg M, Joseph P, Hale B, Beyersmann D. Molecular and cellular mechanisms of cadmium carcinogenesis. Toxicology. 2003 Nov 5;192(2-3):95-117.

10. Snoeckx LH, Cornelussen RN, Van Nieuwenhoven FA, Reneman RS, Van Der Vusse GJ. Heat shock proteins and cardiovascular pathophysiology. Physiol Rev. 2001 Oct;81(4):1461-97. 
11. Ciocca DR, Oesterreich S, Chamness GC, McGuire WL, Fuqua SA. Biological and clinical implications of heat shock protein 27,000 (Hsp27): a review. J Natl Cancer Inst. 1993 Oct 6;85(19):1558-70.

12. Del Razo LM, Quintanilla-Vega B, Brambila-Colombres E, Calderon-Aranda ES, Manno M, Albores A. Stress proteins induced by arsenic. Toxicol Appl Pharmacol. 2001 Dec 1;177(2):132-48.

13. Harris GK, Shi X. Signaling by carcinogenic metals and metal-induced reactive oxygen species. Mutat Res. 2003 Dec 10;533(1-2):183-200.

14. Manca D, Ricard AC, Trottier B, Chevalier G. Studies on lipid peroxidation in rat tissues following administration of low and moderate doses of cadmium chloride. Toxicology. 1991 May;67(3):303-23. 
CHAPTER IV

HSP70 EXPRESSION AND REACTIVE OXYGEN SPECIES GENERATION IN HUMAN BRONCHIAL CELL LINE, BEAS-2B, CAUSED BY EXPOSURE TO MERCURY 


\section{INTRODUCTION}

The previous two chapters (Chapters II and III) detailed the gene and protein expression patterns of Hsp70 in BEAS-2B cells exposed to As and Cd. In this Chapter, Hsp70 gene and protein expression are examined in response to mercury $\left(\mathrm{HgCl}_{2}\right)$ exposure. Hg-induced ROS generation is also examined as a mediator of Hsp70 overexpression in the cells exposed to $\mathrm{Hg}$. From these it is postulated that Hsp70 is a sensitive indicator for monitoring human exposure to $\mathrm{Hg}$ in occupational and environmental exposures. 


\section{RESULTS}

Cytotoxicity of $\mathrm{Hg}$ to BEAS-2B Cells

$\mathrm{Hg}$ is a toxic heavy metal and exposure to cells is believed to induce cellular damage through various molecular and cellular mechanisms. To determine the cytotoxic effects and to select optimal concentrations and exposure time without causing significant cytotoxicity to $\mathrm{Hg}$ in human bronchial epithelial cell line BEAS-2B, we performed a MTT assay (Fig. 21). Cytotoxicity resulting from $\mathrm{Hg}$ increased in a dose and time dependent manner during 3 day exposure time period. On day one, the survival rate was decreased to $88 \%$, and $66 \%$ at 25 , and $50 \mu \mathrm{M}$ concentration of $\mathrm{Hg}$, respectively. On day two, the survival rate decreased to $88 \%$, and $39 \%$ with $25 \mu \mathrm{M}$ and $50 \mu \mathrm{M}$ concentrations of $\mathrm{Hg}$, respectively, compared to control. On day three, the survival rate decreased to $69 \%$, and $32 \%$ with $25 \mu \mathrm{M}$ and $50 \mu \mathrm{M}$ concentrations of $\mathrm{Hg}$, respectively, compared to control. This cytotoxicity data indicated that cytotoxicity is not prominent for 2 days at $25 \mu \mathrm{M}$ of $\mathrm{Hg}$, while significant at $50 \mu \mathrm{M}$ of $\mathrm{Hg}$. On day three, cytotoxicity increased significantly at these two concentrations. Therefore, this dose and time-dependent cytotoxicity was taken into consideration in all further studies.

\section{Expression of Hsp70 Protein is Increased in a Dose-dependent Manner by Hg Exposure}

The expression of Hsp70 protein was observed after exposing BEAS-2B cells to $\mathrm{Hg}$ for 3 and $6 \mathrm{hr}$, followed by recovery periods (0-24 hr). Significant increase of Hsp70 protein was observed with all the $\mathrm{Hg}$ concentrations used (Fig. 22). Hsp70 protein increased approximately to 1.6 and 3.8-fold greater than controls at 25 and $50 \mu \mathrm{M} \mathrm{Hg}$ concentrations, respectively, following a $3 \mathrm{hr}$ exposure and a $12 \mathrm{hr}$ recovery period (Fig. 22, A). It showed further increase approximately to 2.0 and 4.4 -fold at 25 and $50 \mu \mathrm{M}$ concentrations of $\mathrm{Hg}$, respectively, following a $6 \mathrm{hr}$ exposure and $12 \mathrm{hr}$ recovery period 
(Fig. 22, B). Maximum expression was achieved during 12-24 hr recovery periods in the cells exposed to $50 \mu \mathrm{M}$ of $\mathrm{Hg}$ (Fig. 22, C). Even after $96 \mathrm{hr}$ of recovery with fresh media, Hsp70 remained higher compared to control. The Hsp70 ELISA assay was also performed to ensure and quantify the expression of Hsp70 (Fig. 23). In the Hsp70 ELISA assay, Hsp70 protein expression increased approximately 2.5 and 9.2-fold at 25 and $50 \mu \mathrm{M} \mathrm{Hg}$ concentrations, respectively, in the cells with a $3 \mathrm{hr}$ exposure and a $12 \mathrm{hr}$ recovery time (Fig. 23). In the cells with a $6 \mathrm{hr}$ exposure and a $12 \mathrm{hr}$ recovery time, the expression was increased 2.8 and 8.3-fold at 25 and $20 \mu \mathrm{M} \mathrm{Hg}$ concentrations, respectively (Fig. 23).

\section{Hsp70 mRNA Expression in BEAS-2B Cells Exposed to $\mathrm{Hg}$}

It has been documented that Hsp70 protein is encoded by three different genes, called Hsp70A, Hsp70B, and Hsp70C. To investigate these three mRNA expression levels in the cells exposed to $\mathrm{Hg}$ exposure, RT-PCR technique used three different isoform specific primers. The expression of mRNA of the three isoforms was analyzed after a $6 \mathrm{hr}$ exposure and a recovery period of 0-24 hr. Figure 24, D shows the agarose gel picture taken from one typical experiment used in quantitation. Graphic illustration of the mean values from three independent experiments on the expression of these Hsp genes, compared to mRNA from the G3PDH housekeeping gene, is presented in Figure 24, A, B and C. The analysis showed that Hsp70 gene expression had a differential pattern when the cells were exposed to $\mathrm{Hg}$. Hsp70A mRNA expression was not significantly changed in all the $\mathrm{Hg}$ concentrations tested suggesting that this gene is not sensitive to $\mathrm{Hg}$ exposure (Fig. 24, A). Hsp70B mRNA expression was increased approximately 12.2 , and 15.8-fold at 25 and $50 \mu \mathrm{M} \mathrm{Hg}$ concentrations, respectively, after a zero hr recovery period (Fig. 24, B). At 12-24 hours of recovery, the Hsp70B mRNA expression returned to the control level in $25 \mu \mathrm{M}$ concentration of $\mathrm{Hg}$; however the 
expression was still significantly higher in $50 \mu \mathrm{M}$ of $\mathrm{Hg}$ exposure. The expression pattern of Hsp70C mRNA was similar to that of Hsp70B mRNA. The Hsp70C mRNA expression was significantly increased approximately 1.5 -fold at both 25 and $50 \mu \mathrm{M} \mathrm{Hg}$ concentrations after a zero $\mathrm{hr}$ recovery period (Fig. 24, C). Hsp70C mRNA returned to the control level during 6-24 $\mathrm{hr}$ of recovery time. Taken together, it was apparent that the expression of mRNA of Hsp70B and Hsp70C isoforms are rapidly increased and are responsible for overexpression of $\mathrm{Hsp} 70$ protein in response to $\mathrm{Hg}$ exposure, while Hsp70A is not significantly stimulated. It was also obvious that Hsp70B was the most sensitive indicator in BEAS-2B cells exposed to $\mathrm{Hg}$.

Effect of Antioxidants on Hg-induced Hsp70 Protein Expression by Western Blotting

The effects of antioxidants on Hg-induced Hsp70 expression are shown in Figure 25. SOD, a ${ }^{\circ} \mathrm{O}_{2}^{-}$radical scavenger that generates $\mathrm{H}_{2} \mathrm{O}_{2}$, and $\mathrm{SF}$, an ${ }^{\circ} \mathrm{OH}$ radical scavenger, did not show a significant effect (10-15\%) on the inhibition of Hsp70 protein expression. Induction of $\mathrm{Hsp} 70$ protein was significantly inhibited by catalase, a $\mathrm{H}_{2} \mathrm{O}_{2-}$ scavenging enzyme, and $\mathrm{N}$-acetylcysteine, a thiol-containing antioxidant, by 4.1 and 3.9fold respectively compared to cells exposed to $\mathrm{Hg}$ without any antioxidant. These results suggest that ROS, especially $\mathrm{H}_{2} \mathrm{O}_{2}$, play an important role in $\mathrm{Hg}$-induced $\mathrm{Hsp} 70$ protein expression.

\section{Generation of Hydroxyl Radicals by $\mathrm{Hg}$}

To test whether $\mathrm{Hg}$ induces generation of ROS by interaction with cells, we exposed BEAS-2B cells to $100 \mu \mathrm{M}$ of $\mathrm{Hg}$ for $10 \mathrm{~min}$ in the presence DMPO and phosphate buffer at $37^{\circ} \mathrm{C}$ with or without ROS scavengers. ESR spectra, recorded 10 min after the initiation of reaction at a pH 7.4 in phosphate buffer containing $200 \mathrm{mM}$ DMPO and $\mathrm{Hg}$, showed a typical 1:2:2:1 quartet with hyperfine splittings of $a_{H}=a_{N}=$ 
$14.9 \mathrm{G}$. Based on these splitting constants of hydrogen and nitrogen, the signal was assigned to a $\mathrm{DMPO} /{ }^{\circ} \mathrm{OH}$ adduct, demonstrating the generation of ${ }^{\circ} \mathrm{OH}$ radicals. Omission of cells, or DMPO with cells failed to produce the ${ }^{\circ} \mathrm{OH}$ signal. Addition of catalase, a $\mathrm{H}_{2} \mathrm{O}_{2}$ scavenging enzyme, and $\mathrm{SF}$, a ${ }^{\circ} \mathrm{OH}$ radical scavenger minimized ${ }^{\circ} \mathrm{OH}$ generation, while NADPH increased the signal as expected (Fig. 26).

Detection of Intracellular ROS Generation by Exposure to Hg using Confocal Microscopy Intracellular ROS generation in BEAS-2B cells exposed to $\mathrm{Hg}$ was tested using confocal microscopy. BEAS-2B cells were exposed with $\mathrm{Hg}$ in the presence of $\mathrm{H}_{2}$ DCFDA, a specific fluorescent dye for $\mathrm{H}_{2} \mathrm{O}_{2}$, or dihydroethidium, a specific fluorescent dye for $\cdot \mathrm{O}_{2^{-}}$. Images are displayed in pseudocolor where blue indicates areas of low intensity and increasingly high intensity areas are green $<$ yellow $<$ red $<$ white. In the presence of increasing concentrations of $\mathrm{Hg}$ the intensity of fluorescence increased significantly. Intracellular generation of $\mathrm{H}_{2} \mathrm{O}_{2}$ and ${ }^{\circ} \mathrm{O}_{2}^{-}$were observed after exposure to 50 and $100 \mu \mathrm{M}$ of $\mathrm{Hg}$ for $1 \mathrm{hr}$ and results obtained are displayed (Fig. 27). These studies suggest that both $\mathrm{H}_{2} \mathrm{O}_{2}$ and ${ }^{\circ} \mathrm{O}_{2}^{-}$are generated in a dose-dependent manner. 


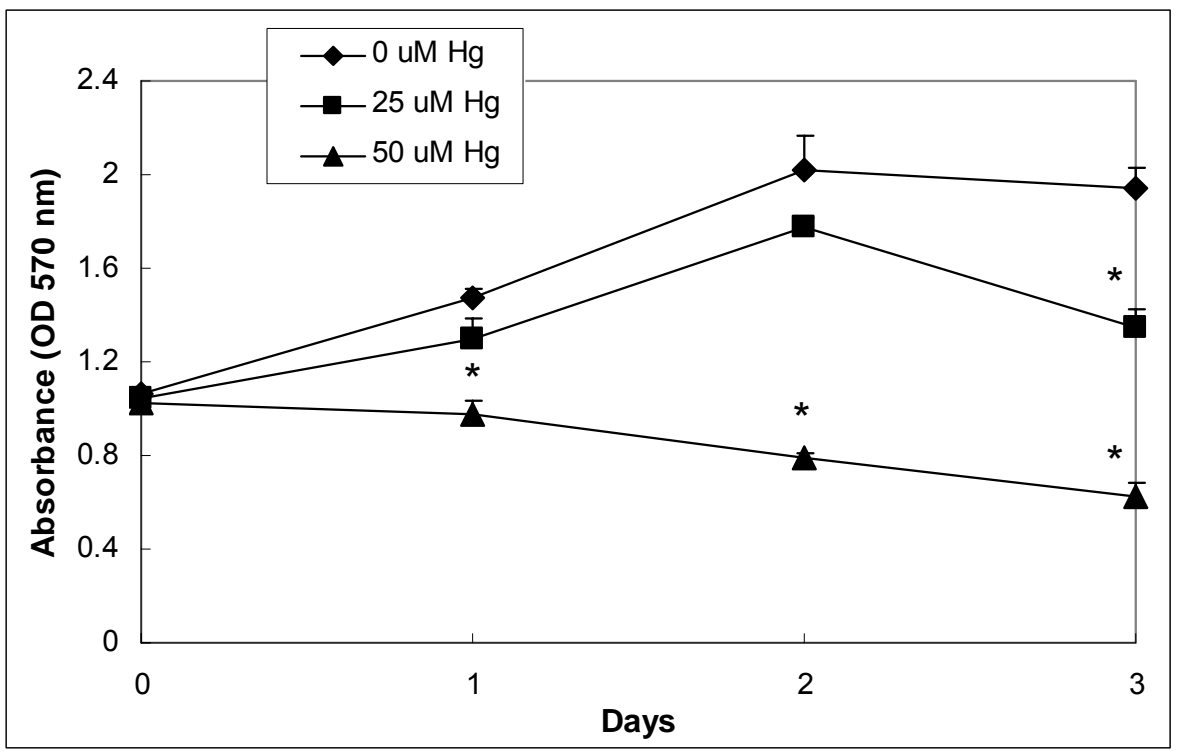

Figure 21. Cytotoxicity of $\mathrm{Hg}$ to BEAS-2B cells determined by the MTT assay. BEAS-2B cells were seeded in 96-well plates at $2 \times 10^{4}$ cell/well and incubated for $24 \mathrm{hr}$. The medium was changed, and cells in triplicate were exposed to different $\mathrm{Hg}(0-50 \mu \mathrm{M})$ concentrations for 3 days. The optical density was measured at $570 \mathrm{~nm}$, and values presented represent the mean \pm SE of six assay wells from two independent experiments. *Indicates a significant decrease of cell viability from control $(p<0.05)$. 


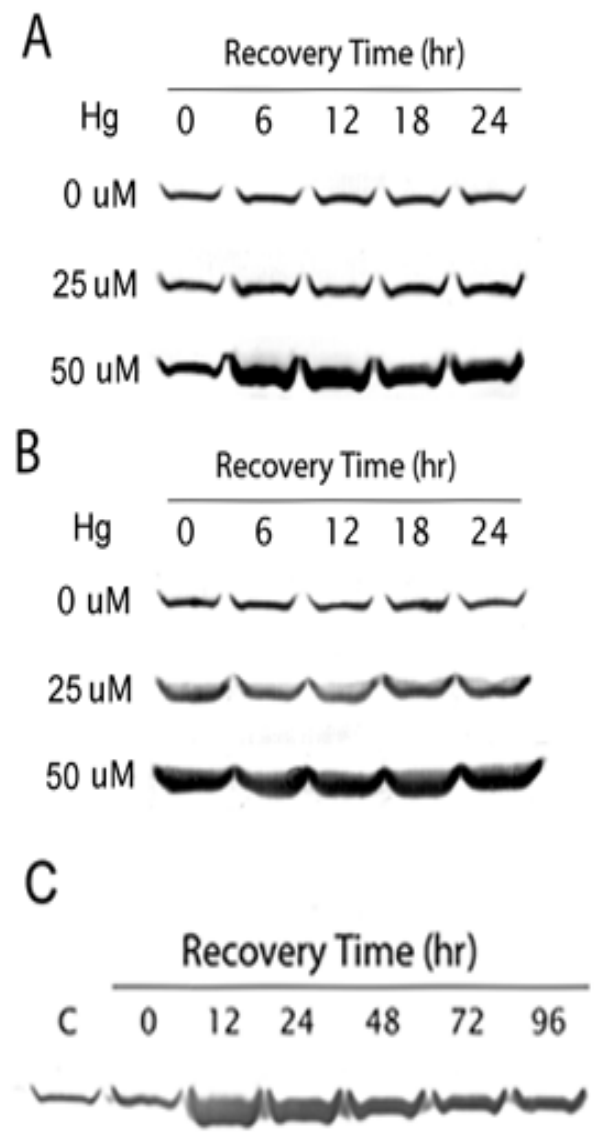

Figure 22. Hsp70 protein detection by Western blotting during recovery periods. BEAS-2B cells were exposed to $\mathrm{Hg}$ for two different times, $3 \mathrm{hr}(\mathrm{A})$ and $6 \mathrm{hr}(\mathrm{B})$, followed by recovery with fresh media for five different time periods (0-24 hr) as indicated. (C) Cells were exposed to $\mathrm{Hg}$ for $3 \mathrm{hr}$ and recovered for $96 \mathrm{hr}$ periods. Cells were harvested and $30 \mu \mathrm{g}$ of total protein samples separated by $10 \%$ SDS-PAGE were transferred onto $0.2 \mu \mathrm{m}$ nitrocellulose membranes. Western blotting was performed with the anti-Hsp70 monoclonal antibody. 


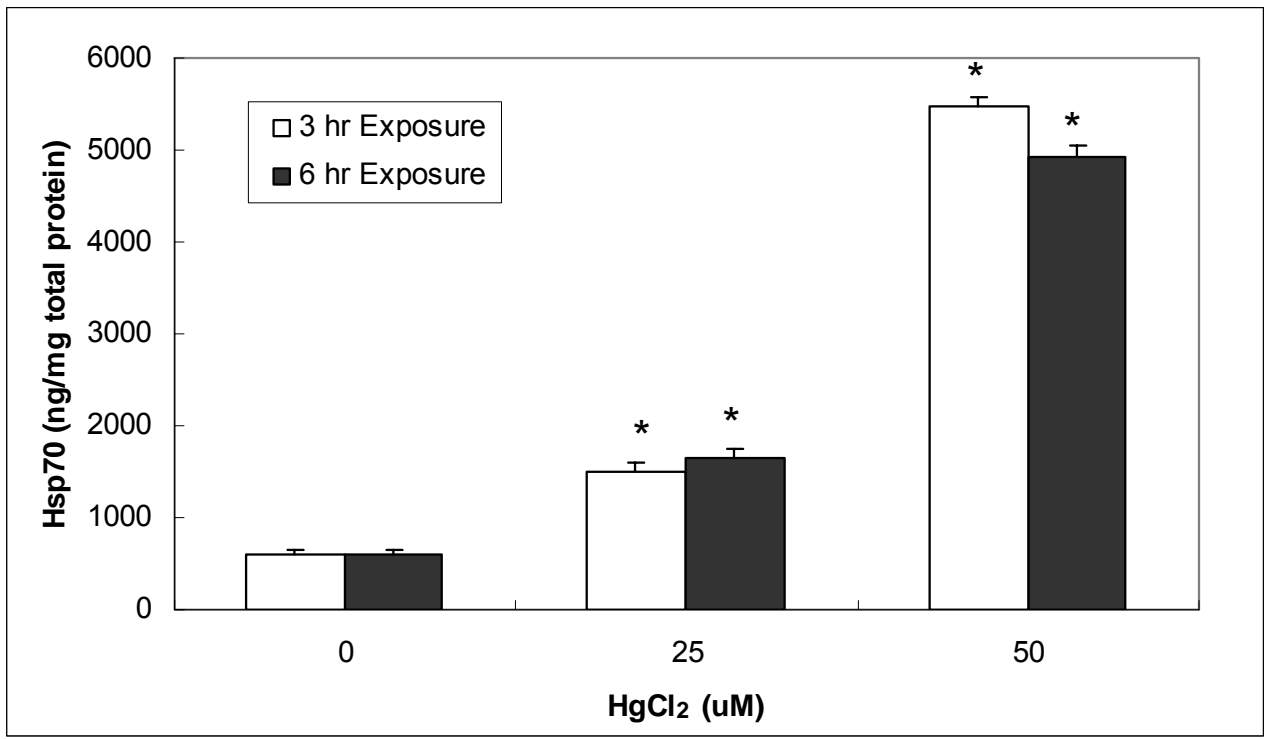

Figure 23. Hsp70 protein detection by ELISA. BEAS-2B cells were exposed to $\mathrm{Hg}$ for two different times, $3 \mathrm{hr}$ and $6 \mathrm{hr}$, followed by recovery with fresh media for $12 \mathrm{hr}$. Cells were harvested and the total protein samples $(0.025 \mu \mathrm{g} / \mu \mathrm{l})$ were tested by $\mathrm{Hsp} 70$ ELISA kit. The absorbance of samples was measured at $450 \mathrm{~nm}$, using a microplate spectrophotometer. The values of Hsp70 concentrations ( $\mathrm{ng} / \mathrm{mg}$ total protein) of each sample presented represent the mean \pm SE of six assay wells from two independent experiments. *Indicates a significant increase from control $(p<0.05)$. 

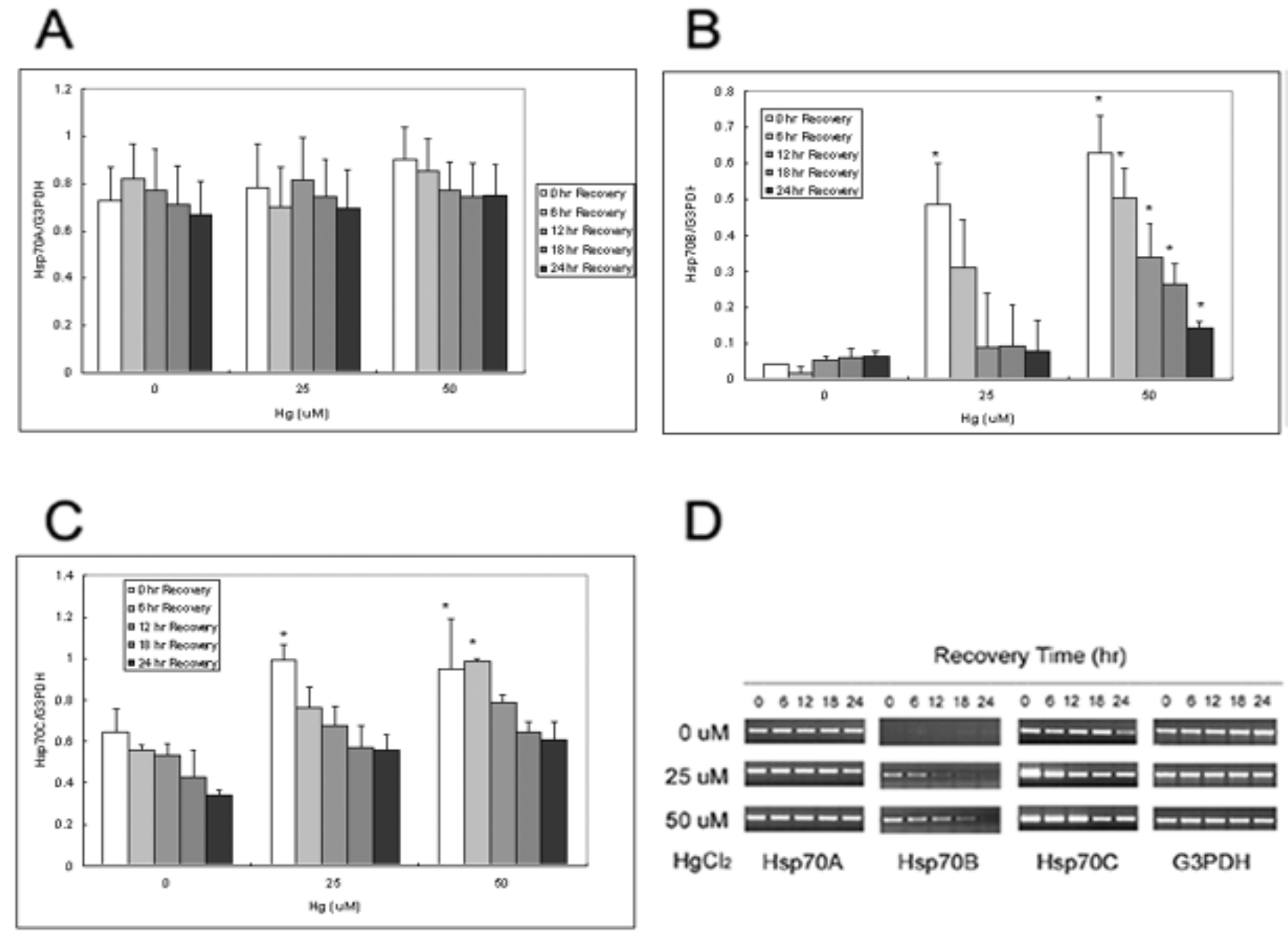

Figure 24. RT-PCR analysis of mRNA from BEAS-2B cells exposed to $\mathrm{Hg}$. BEAS-2B cells were exposed to $0-50 \mu \mathrm{M} \mathrm{Hg}$ for $6 \mathrm{hr}$, followed by a $0-24 \mathrm{hr}$ recovery period. The values of $\operatorname{Hsp70A}(\mathrm{A})$, Hsp70B (B), and Hsp70C (C) mRNA expression presented represent mean \pm SE of relative integrated optical density of bands divided by that for the housekeeping gene, G3PDH, from three independent experiments. (D) A representative agarose gel picture from one of the experiments used for data analysis. *Indicates a significant increase from control $(p<0.05)$. 


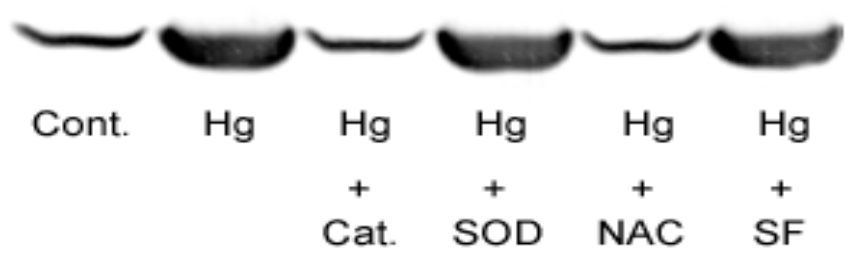

Figure 25. Effect of antioxidants and other reagents on Hg-induced Hsp70 protein expression by Western blotting. BEAS-2B cells were exposed to $50 \mu \mathrm{M} \mathrm{Hg}$ with or without antioxidants for $6 \mathrm{hr}$. Western blotting was performed. The concentrations of the antioxidants and other reagents used were: catalase, 2,000 units/ml; superoxide dismutase (SOD), 2,000 units/ml; $N$-acetylcysteine (NAC), 10mM; sodium formate (SF), $50 \mathrm{mM}$. 

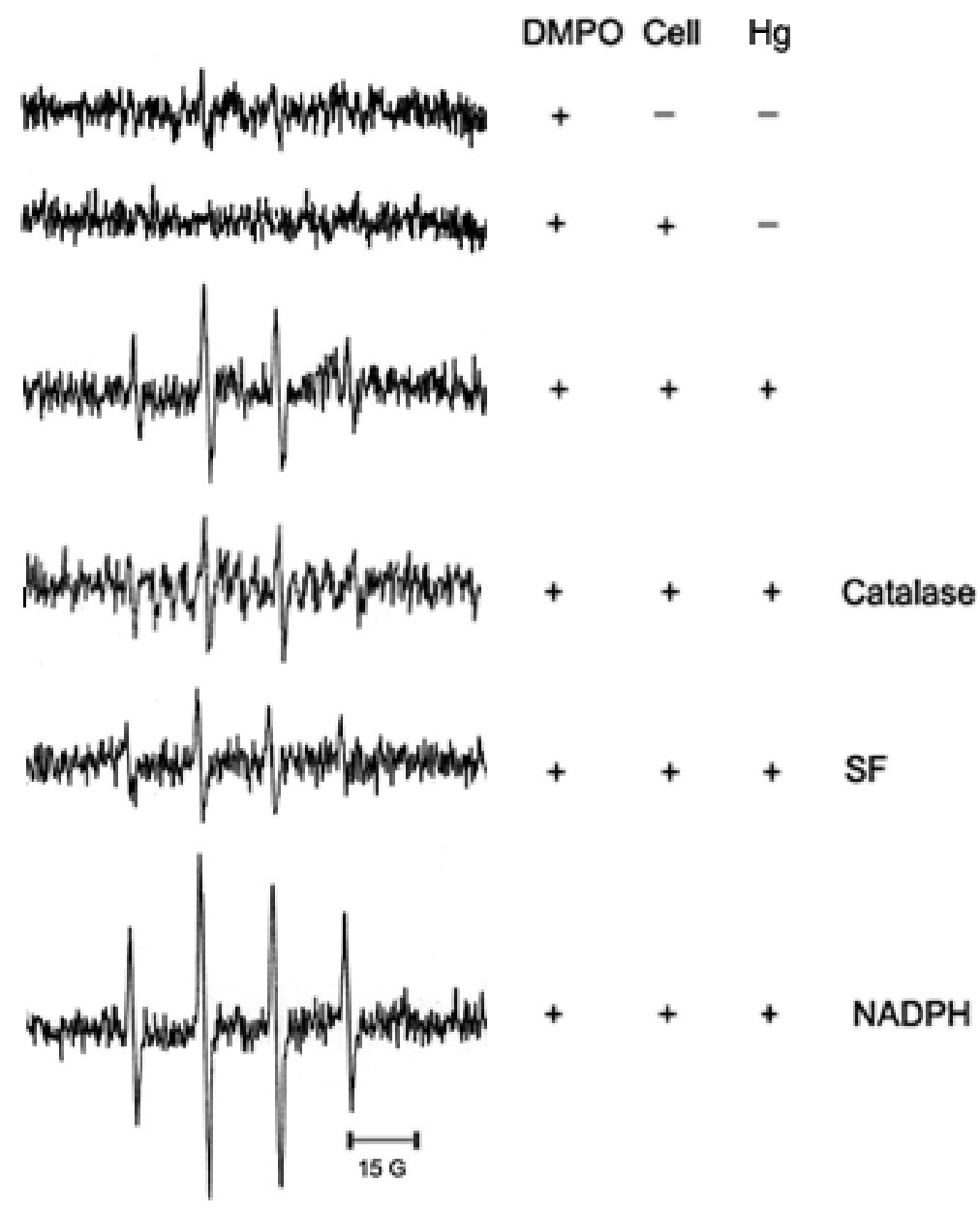

Figure 26. ESR spectra generated by DMPO/OH adducts obtained from BEAS2B cells treated with $\mathrm{Hg}$. BEAS-2B cells $\left(1 \times 10^{6}\right)$ were incubated with $200 \mathrm{mM}$ of DMPO, and $100 \mu \mathrm{M}$ of $\mathrm{Hg}$ for $10 \mathrm{~min}$ at $37^{\circ} \mathrm{C}$. The spectra were integrated by 3 scans. The spectrometer settings were: receiver gain, $6.32 \times 10^{4}$; time constant, $40.960 \mathrm{~ms}$; modulation amplitude, $1.0 \mathrm{G}$; scan time, $41.943 \mathrm{~s}$; magnetic field, $3490 \pm 50 \mathrm{G}$. The concentrations of the enzymes and reagent used were: catalase, 2,000 units $/ \mathrm{ml}$; sodium formate (SF), $500 \mathrm{mM}$; NADPH, 5mM. 

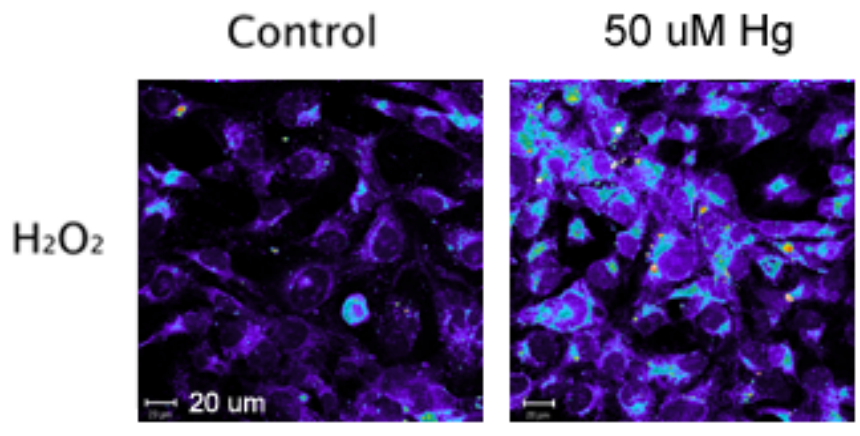

$100 \mathrm{uM} \mathrm{Hg}$
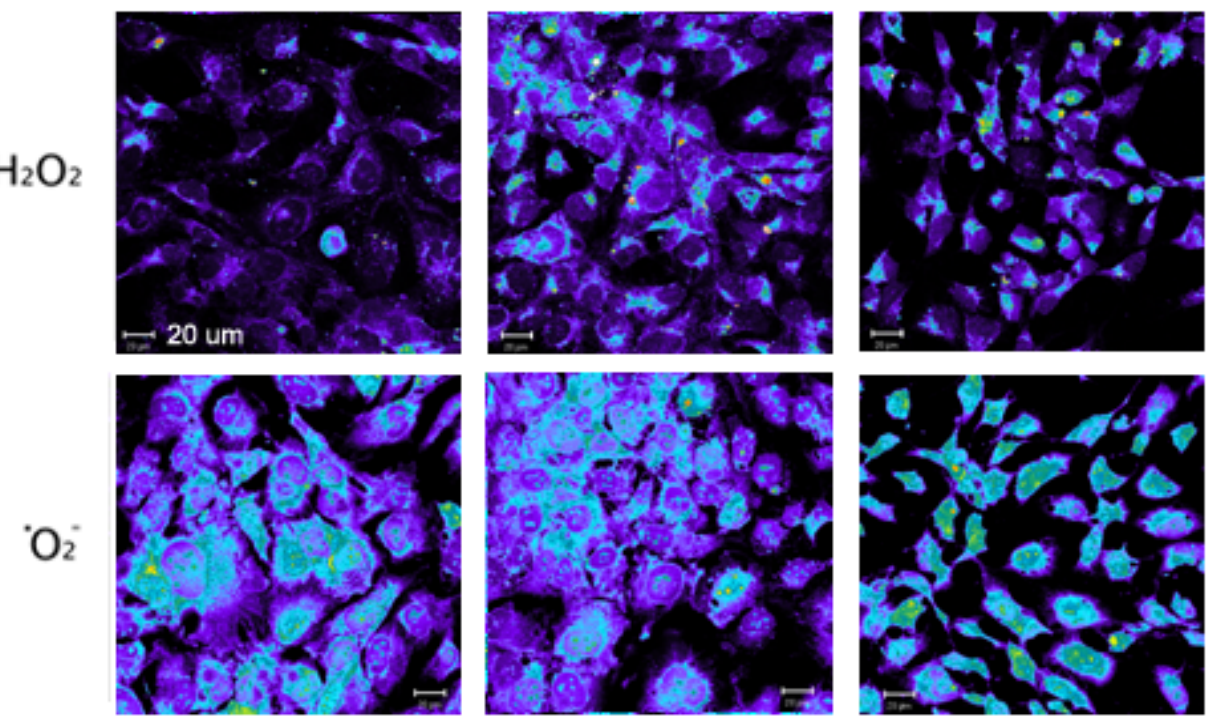

Figure 27. Detection of intracellular $\mathrm{H}_{2} \mathrm{O}_{2}$ and $\mathrm{O}_{2}$ generation by exposure to $\mathrm{Hg}$ using confocal microscopy. BEAS-2B cells $\left(1 \times 10^{6}\right)$ were exposed with either 50 or $100 \mu \mathrm{M}$ of $\mathrm{Hg}$ in the presence of $\mathrm{H}_{2}$ DCFDA $(25 \mu \mathrm{M})$ or dihydroethidium $(10 \mu \mathrm{M})$ for $1 \mathrm{hr}$. The cells were washed with PBS, fixed with $10 \%$ buffered formalin for $10 \mathrm{~min}$, and mounted on glass slides. The images were captured with a laser scanning confocal microscope. The bright green, yellow and red areas in the cells represent oxidized DCFHDA and dihydroethidium indicating the intracellular generation and localization of $\mathrm{H}_{2} \mathrm{O}_{2}$ and ${ }^{\circ} \mathrm{O}_{2}^{-}$in BEAS-2B cells. 


\section{DISCUSSION}

Mercury is ubiquitous in environment and industries in low levels but is very toxic and harmful to human health. There are three forms of mercury; elemental, organic, and inorganic mercury $(1,2)$. Elemental mercury vapor is easily absorbed in the lung while both organic and inorganic mercury are absorbed through lung, skin, and GI track (3). Therefore, human lung is the major target for toxicity of mercury. Vaporized elemental mercury is absorbed by the lung and can bind to sulfhydryl groups (1). Mercury induced oxidative stress is believed to be the mechanism causing toxicity. Mercury is able to deplete sulfhydryl groups and antioxidants as well as generate ROS (4-6).

As stated in previous chapters, heat shock proteins are a group of chaperone proteins that are induced by a variety of stresses including toxic heavy metals, and ROS (7, 8). Inducible forms of Hsps, such as Hsp70 have cytoprotective roles and can be released into the extracellular milieu upon injury or necrosis of cells. Heavy metals have the potential to generate ROS through a Fenton-type reaction, which may induce oxidative stress resulting in the upregulation of heat shock protein. Also, metal induced oxidative stresses include depletion of antioxidants, and binding to sulfhydryl groups which are believed to stimulate heat shock protein expression $(5,9)$.

In this chapter, studies were designed to investigate the effects of mercuric chloride $\left(\mathrm{HgCl}_{2}\right)$ on Hsp70 protein expression and the mechanisms involved, particularly ROS generation. Also, the goal of this study was to explore whether Hsp70 is a sensitive biomarker for mercury-induced cellular injury. Results of these studies demonstrated that exposure of $\mathrm{Hg}$ to the human bronchial epithelial cell line, BEAS-2B, induced a significant expression of Hsp70 protein and mRNA in a time- and dosedependent manner. Hsp70 protein accumulation reached the maximum after a $6 \mathrm{hr}$ of recovery at $50 \mu \mathrm{M}$ exposure to $\mathrm{Hg}$. This maximum accumulation continued until a $24 \mathrm{hr}$ 
of recovery period, followed by a decrease of protein during next recovery periods. This implies that Hsp70 protein can be a potential biomarker for monitoring cellular damages induced by $\mathrm{Hg}$.

The expression of three highly homologous Hsp70 genes (Hsp70A, Hsp70B and Hsp70C) was investigated. Hsp70B, and Hsp70C mRNA was significantly overexpressed after a $6 \mathrm{hr}$ exposure to $\mathrm{Hg}$, while Hsp70A expression was not changed. A dramatic increase of Hsp70B mRNA expression could be used as a sensitive indicator for $\mathrm{Hg}$-induced cell injury. It is assumed that transcription is responsible for regulation of Hsp70 expression. It is further confirmed by Actinomycin D, a transcription inhibitor, which effectively repressed the induction of Hsp70 protein synthesis. Translation or other regulation processes are probably involved in $\mathrm{Hg}$-induced $\mathrm{Hsp} 70$ protein expression as that of arsenic and cadmium.

The increased generation of ROS appears to be an important stimulant in the induction of Hsp70. Mercury can induce cellular oxidative stress including ROS generation and depletion of antioxidants. Therefore, the relationship between the Hsp70 protein expression and $\mathrm{Hg}$-induced oxidative damage was investigated. Treatment with catalase, a $\mathrm{H}_{2} \mathrm{O}_{2}$ scavenging enzyme, and $\mathrm{N}$-acetylcysteine (NAC), a thiol-containing general antioxidant showed a decrease of Hsp70 protein expression when cells were exposed to $\mathrm{Hg}$. This result indicated that $\mathrm{H}_{2} \mathrm{O}_{2}$ is an important mediator in $\mathrm{Hg}$-induced $\mathrm{Hsp} 70$ upregulation and binding of $\mathrm{Hg}$ with thiol groups on the active sites of proteins promotes Hsp70 expression.

This study showed that $\mathrm{Hg}$ can generate ROS $\left(\mathrm{O}_{2}^{-}\right.$and $\left.\mathrm{H}_{2} \mathrm{O}_{2}\right)$ inside of cells using fluorescence staining of $\mathrm{Hg}$-exposed cells. ROS $\left({ }^{\circ} \mathrm{OH}\right)$ generation was observed using ESR spectroscopy as the final end product of interaction between $\mathrm{Hg}$ and BEAS2B cells. However, the lipid peroxidation was not significantly increased by $\mathrm{Hg}$ exposure in this cell type (data not shown). Taken together, our findings suggest that Hsp70 is a 
sensitive biomarker of cellular stress or perturbations caused by mercury exposure. Oxidative damage appears to play a role in Hg-induced Hsp70 expression. 


\section{REFERENCES}

1. Krantz A, Dorevitch S. Metal exposure and common chronic diseases: a guide for the clinician. Dis Mon. 2004 May;50(5):220-62.

2. Counter SA, Buchanan LH. Mercury exposure in children: a review. Toxicol Appl Pharmacol. 2004 Jul 15;198(2):209-30.

3. Jarup L. Hazards of heavy metal contamination. Br Med Bull. 2003;68:167-82.

4. De Flora S, Bennicelli C, Bagnasco M. Genotoxicity of mercury compounds. A review. Mutat Res. 1994 Feb;317(1):57-79.

5. Stohs SJ, Bagchi D. Oxidative mechanisms in the toxicity of metal ions. Free Radic Biol Med. 1995 Feb;18(2):321-36.

6. Goering PL, Morgan DL, Ali SF. Effects of mercury vapor inhalation on reactive oxygen species and antioxidant enzymes in rat brain and kidney are minimal. J Appl Toxicol. 2002 May-Jun;22(3):167-72.

7. Lindquist S, Craig EA. The heat-shock proteins. Annu Rev Genet. 1988;22:631-77.

8. Fink AL. Chaperone-mediated protein folding. Physiol Rev. 1999 Apr;79(2):425-49.

9. Ercal N, Gurer-Orhan H, Aykin-Burns N. Toxic metals and oxidative stress part I: mechanisms involved in metal-induced oxidative damage. Curr Top Med Chem. 2001 Dec;1(6):529-39. 


\section{CHAPTER V}

CORRELATES OF OXIDATIVE STRESS AND FREE RADICAL ACTIVITY IN THE SERUM OF ASYMPTOMATIC SHIPYARD WELDERS 


\section{INTRODUCTION}

Approximately 800,000 to $1,000,000$ workers are employed as full time welders on a worldwide basis $(1,2)$. Welding generates fumes that may contain many toxic materials including metals, such as iron, manganese, chromium and nickel, and several toxic gases, such as carbon monoxide, ozone and nitrogen oxides. These metals and gases, generated in industrial operations are ubiquitous pollutants at occupational worksites and environment with the potential to produce adverse health effects. Fumes generated from mild steel welding usually contain $\sim 80 \%$ or more of iron and some manganese, while stainless steel electrodes contain $20 \%$ chromium and $10 \%$ nickel (2). Welding fumes can cause a variety of diseases from minor syndromes, such as headache, nausea and metal fume fever, to severe health effects, such as occupational asthma, pneumoconiosis, bronchitis, lung cancer and manganism (2, 3-7). It has been shown that chromium, nickel, and iron can produce ROS such as hydroxyl radicals $\left({ }^{\circ} \mathrm{OH}\right)$, superoxide anion $\left(\mathrm{O}_{2}^{-}\right)$, singlet oxygen $\left(\mathrm{O}^{1}\right)$ and $\mathrm{H}_{2} \mathrm{O}_{2}$. This increased production of ROS, can trigger several key signaling events to provoke adverse biochemical and molecular abnormalities in the target cells leading to a disease state. The effects of welding fume exposure have been widely studied both in human and in animals but a comprehensive understanding of the biochemical and biological changes occurring in exposed populations is still unclear. The purposes of this study were to investigate the effects of occupational exposure to welding fumes and to evaluate correlates of oxidative stress in the serum of currently employed asymptomatic welders and evaluate changes with duration of exposure to controls matched for age and cigarette smoking. 


\section{RESULTS}

\section{Study Population}

A total 197 asymptomatic active welders and 150 white-collar workers as controls were studied. Welders and control populations were similar in respect to age, height, weight, smoking status and other variables except welding exposure (Tables I-II). Clinical and hematological studies revealed no major underlying disease processes in either group (data not shown).

To explore the changes in oxidative stress potentially induced by exposure to the welding fumes, the welders were divided into three groups based on work history in welding operations from 1-10 years, 11-20 years and 21 or more years. Demographic characteristics of these three groups of welders showing the number of welders in each group with information on smoking are presented in Table IV. Mean exposure duration of the three groups were $3.91 \pm 2.95$ years, $16.52 \pm 2.91$ years, and $25.39 \pm 2.74$ years, respectively. For welders in the study group the minimum exposure duration was 1.3 years and maximum exposure duration was 33 years.

In biomarkers of oxidative stress in the serum of controls and welders, data presented are the means and standard errors of controls matched for age and smoking and welders. Welders are grouped in 1-10 years $(n=142), 11-20$ years $(n=27)$, and 21 or more years $(n=28)$. Overall comparisons of welding exposure are made with all controls $(n=150)$ and all welders $(n=197)$. Comparisons of independent effects of welding and smoking are evaluated in nonsmoker controls $(n=75)$, smoker controls $(n=$ $75)$, nonsmoker welders $(n=72)$, and smoker welders $(n=125)$.

Total Protein and Albumin 
In welders with 1-10 years of exposure, total protein concentrations were significantly increased $(p=0.001)$ and with continued exposure of $11-20$ years, protein concentrations remained elevated. However, with 21 or more years of welding exposure the protein levels in the serum declined significantly but still remained moderately above the normal levels (Fig. 28). Serum albumin on the other hand remained at comparable levels to controls in 1-10 years, and 11-20 years of exposure groups (Fig. 29). In welders with 21 or more years of exposure, serum albumin appeared lower than the levels in control, however, this moderate drop in the levels of serum albumin was not significant.

\section{Total Antioxidant Status}

Total antioxidant levels in the serum of welders with exposure history to 1-10 years, 11-20 years and 21 or more years of welding showed a significant upregulation ( $p$ $<0.02$ ) in all the three exposure groups compared to controls (Fig. 30). However, there was no evidence of a linear relationship to total antioxidant status and welding exposure. Effect of age was significant, but this influence of age also was not influential in total antioxidant status and welding exposure (data not shown).

\section{Glutathione Peroxidase (GPx)}

GPx enzyme activity showed a significant and steady upregulation in all three exposure groups of welders compared to controls indicative of a moderate welding exposure relationship (Fig. 31). In welders with 21 or more years of exposure this upregulation was not significantly different from the group with 11-20 years of exposure.

\footnotetext{
Manganese Superoxide Dismutase (Mn-SOD)
} 
Mn-SOD in the serum showed a mild nonsignificant upregulation in welders with 1-10 years and 11-20 years of welding exposure compared to controls. In welders with continued exposure for 21 or more years, Mn-SOD was downregulated compared to controls and other exposure groups (Fig. 32). However, when influence of age was included in the analysis this downregulation was found to be not significantly influenced by welding exposure.

\section{Aconitase}

Aconitase enzyme activity showed a significant increase in welders with 1-10 years of welding exposure compared to controls (Fig. 33). In welders with 11-20 years exposure aconitase declined significantly compared to 1-10 years exposure group but remained elevated more than in controls (Fig. 33). In welders with 20 or more years of exposure aconitase activity increased significantly more than in all other exposure groups (Fig. 33). Overall welding exposure showed a significant effect and age was not influential in this welding effect.

Heat Shock Protein 70

Comparison of welders as a whole and in three exposure groups with 1-10, 1120 , and 21 or years of exposure to welding fumes showed Hsp 70 was not significantly changed (data not shown).

\section{ROS Generation Potential}

The potential to generate ROS by chemiluminescence $(C L)$ was monitored in the serum samples of welders in relation to controls. The potential to generate ROS by the serum samples of welders as indicators was apparent in an exposure-dependent manner. In welders with 1-10 and 11-20 years of welding exposure there was a 
moderate increasing trend in ROS generation by serum as monitored by CL. However, due to high variability there were no significant differences between controls and welders. A significant increasing potential to generate ROS by the serum of welders with 21 or more years of exposure was apparent (Fig. 34). However, inclusion of age in the analysis was found to be moderately influential in CL.

\section{Lipid Peroxidation}

Lipid peroxidation by-product, 8-isoprostane was estimated in the serum of welders and controls as a biomarker of oxidative stress. Welders with 1-10, 11-20 and 20 or more years of exposure history showed significantly increased levels of isoprostane production $148 \%, 123 \%$, and $140 \%$ compared to controls, respectively (Fig. 35).

Comparison of Biomarkers for All Welders and Controls

Welding exposure was not influential in inducing any major changes in albumin levels in welders as a whole compared to controls. On the other hand comparison of protein levels in the serum of all welders to controls showed a significant increase in total protein levels in welders (Fig. 36). Total antioxidant status in welders also showed a moderate, nonsignificant upregulation compared to controls. The increasing trend in serum GPx activity observed with longer exposure to welding was significant in the comparison of all welders with controls (Fig. 36). Comparison of aconitase activity in all welders to controls showed a highly significant increase in welders (Fig. 36). Comparison of all welders with controls showed a significant $10 \%$ increase in the potential of serum of welders to generate ROS (Fig. 36). Comparison of all welders with controls also showed a significant $143 \%$ increase in 8 -isoprostane levels in welders compared to controls (Fig. 36). This significant increase in isoprostane levels is 
indicative of an exposure effect to welding. There was no indication of age influencing this welding exposure effect.

\section{Effect of smoking in controls and welders}

Independent and combined effect of welding and smoking in serum protein, albumin, total antioxidant status, Mn-SOD, aconitase and isoprostane levels were not apparent in comparison of non-smokers and smokers either in controls or welders. Comparison of serum activities of GPx in nonsmokers with smokers showed a nonsignificant downregulation $(6.5 \%)$ in welders with cigarette smoking exposure. A similar nonsignificant downregulation trend was also seen in controls with known current smoking history. Influence of smoking was evident in the comparison of CL in controls and welders. Serum samples from welders and controls with cigarette smoking exposure demonstrated a nonsignificant decrease $(10 \%)$ in oxidant generation potential in welders as result of the combined influence of smoking and welding exposure. 
TABLE I. DEMOGRAPHIC CHARACTERISTICS OF CONTROLS

\begin{tabular}{|c|c|c|c|}
\hline & Total Population & Non-Smokers & Smokers \\
\hline Population \# & 150 & 75 & 75 \\
\hline Age & $35.9 \pm 7.6$ & $36.7 \pm 8.3$ & $35.2 \pm 6.7$ \\
\hline Height (cm) & $172.9 \pm 4.7$ & $173.4 \pm 4.9$ & $172.4 \pm 4.5$ \\
\hline Weight (kg) & $71.5 \pm 8.7$ & $72.2 \pm 8.1$ & $70.7 \pm 9.2$ \\
\hline Smoking Duration & & & $12.8 \pm 5.7$ \\
\hline Cigarettes/Day & & & $12.3 \pm 6.2$ \\
\hline
\end{tabular}

Values are Means $\pm S D$. 
TABLE II. DEMOGRAPHIC CHARACTERISTICS OF ALL WELDERS IN THIS STUDY

\begin{tabular}{|c|c|c|c|}
\hline & Total Population & Non-Smokers & Smokers \\
\hline Population \# & 197 & 72 & 125 \\
\hline Age & $34.9 \pm 10.8$ & $40.7 \pm 13.0$ & $31.5 \pm 7.6$ \\
\hline Height $(\mathrm{cm})$ & $171.2 \pm 5.8$ & $168.8 \pm 6.2$ & $172.5 \pm 5.2$ \\
\hline Weight $(\mathrm{kg})$ & $66.0 \pm 7.9$ & $66.1 \pm 8.0$ & $66.0 \pm 7.9$ \\
\hline Welding Exposure & $8.7 \pm 8.6$ & $13.3 \pm 10.2$ & $6.1 \pm 6.2$ \\
\hline Smoking Duration & & & $12.1 \pm 6.6$ \\
\hline Cigarettes/Day & & & $14.9 \pm 5.6$ \\
\hline Blood [Pb] $(\mu \mathrm{g} / \mathrm{dl})$ & $5.5 \pm 1.6$ & $5.3 \pm 1.7$ & $5.6 \pm 1.5$ \\
\hline Blood [Mn] $(\mu \mathrm{g} / \mathrm{dl})$ & $1.5 \pm 0.4$ & $1.6 \pm 0.4$ & $1.4 \pm 0.3$ \\
\hline
\end{tabular}

Values are Means $\pm S D$. 
TABLE III. METAL CONCENTRATIONS $\left(\mathrm{mg} / \mathrm{m}^{3}\right)$ IN THE AMBIENT AIR AT WELDING SITES $(\mathrm{N}=44)$

\begin{tabular}{|c|c|c|c|c|c|c|c|}
\hline Fume & $\mathrm{Mn}$ & $\mathrm{Fe}$ & $\mathrm{Zn}$ & $\mathrm{Pb}$ & $\mathrm{Cr}$ & $\mathrm{Cu}$ & $\mathrm{Ni}$ \\
\hline 13.2 & 1.1 & 3.3 & 2.0 & 0.005 & 0.006 & 0.009 & 0.004 \\
\pm 1.8 & \pm 2.0 & \pm 2.0 & \pm 1.8 & \pm 2.1 & \pm 1.9 & \pm 1.9 & \pm 3.2 \\
\hline
\end{tabular}

Values are Geometric Means $\pm S D$. 
TABLE IV. DEMOGRAPHIC CHARACTERISTICS OF WELDERS BASED ON EXPOSURE DURATION

\begin{tabular}{|c|c|c|c|c|c|c|}
\hline & \multicolumn{2}{|c|}{$1-10$ years Exposure } & \multicolumn{2}{c|}{$11-20$ years Exposure } & \multicolumn{2}{c|}{$21+$ years Exposure } \\
\hline Smoking Status & NS & S & NS & S & NS & S \\
\hline Population \# & 39 & 103 & 10 & 17 & 23 & 5 \\
\hline Age & $30.4 \pm 7.5$ & $29.1 \pm 4.2$ & $48.4 \pm 8.4$ & $39.7 \pm 7.2$ & $54.7 \pm 0.6$ & $55.2 \pm 1.1$ \\
\hline Height $(\mathrm{cm})$ & $171.2 \pm 4.6$ & $173.1 \pm 5.0$ & $168.2 \pm 6.9$ & $171.7 \pm 4.7$ & $165.0 \pm 6.4$ & $164.2 \pm 4.7$ \\
\hline Weight $(\mathrm{kg})$ & $66.9 \pm 7.4$ & $66.4 \pm 7.8$ & $65.7 \pm 5.7$ & $65.9 \pm 7.8$ & $64.8 \pm 9.8$ & $57.4 \pm 7.1$ \\
\hline Blood [Pb] $(\mu \mathrm{g} / \mathrm{dl})$ & $5.6 \pm 2.1$ & $5.6 \pm 1.5$ & $5.2 \pm 1.5$ & $5.4 \pm 1.5$ & $5.0 \pm 0.9$ & $5.3 \pm 1.0$ \\
\hline Blood [Mn] $(\mu \mathrm{gg} / \mathrm{dl})$ & $1.5 \pm 0.3$ & $1.4 \pm 0.3$ & $1.7 \pm 0.3$ & $1.5 \pm 0.4$ & $1.7 \pm 0.4$ & $1.7 \pm 0.3$ \\
\hline
\end{tabular}

Values are Means \pm SD. NS=Non-Smoker; S=Smoker. 


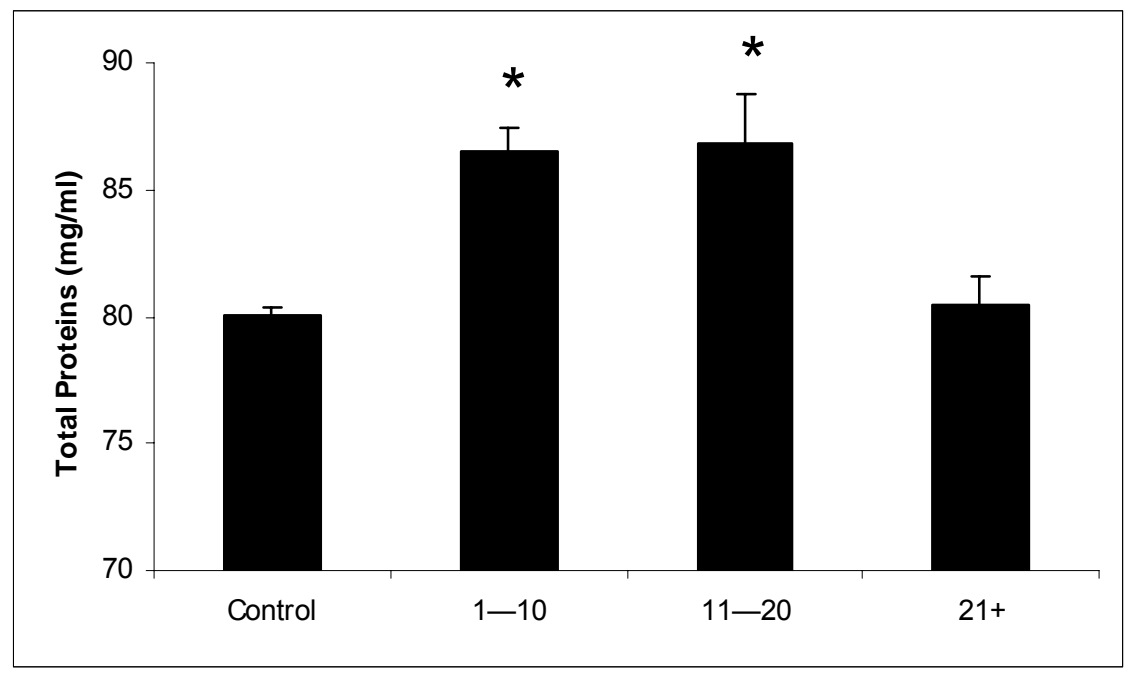

Figure 28. Serum concentrations of total proteins in controls and welders.

Serum concentrations of total proteins in controls and welders with 1-10 years, 11-20

years, and 21 or more years of exposure in shipyard welding. A significant $(p=0.001)$

increase in serum proteins is evident for 1-10 and 11-20 years exposure. With

continued exposure to 21 or more years to welding serum proteins showed a significant $(p=0.008)$ depletion from other welders. 


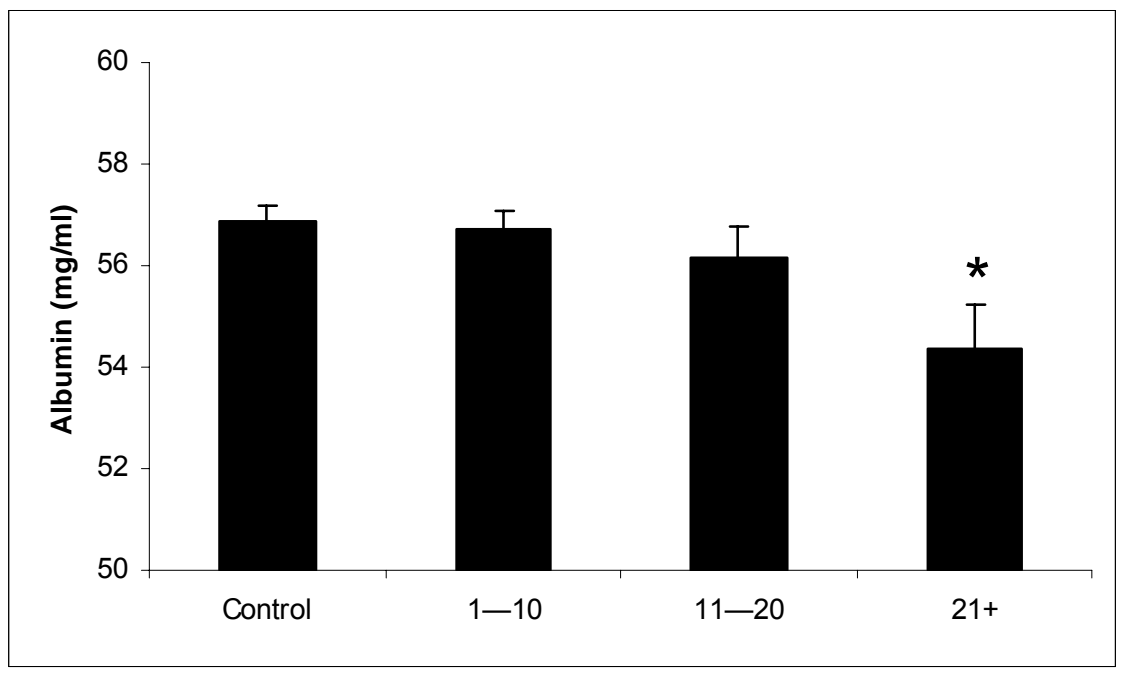

Figure 29. Serum albumin levels in controls and welders. Serum albumin levels in controls and welders with 1-10 years, 11-20 years, and 21 or more years of exposure in shipyard welding. Albumin levels showed a moderate decline in welders with 11-20 years of exposure and then a nonsignificant $(p=0.07)$ depletion with 21 or more years of exposure. 


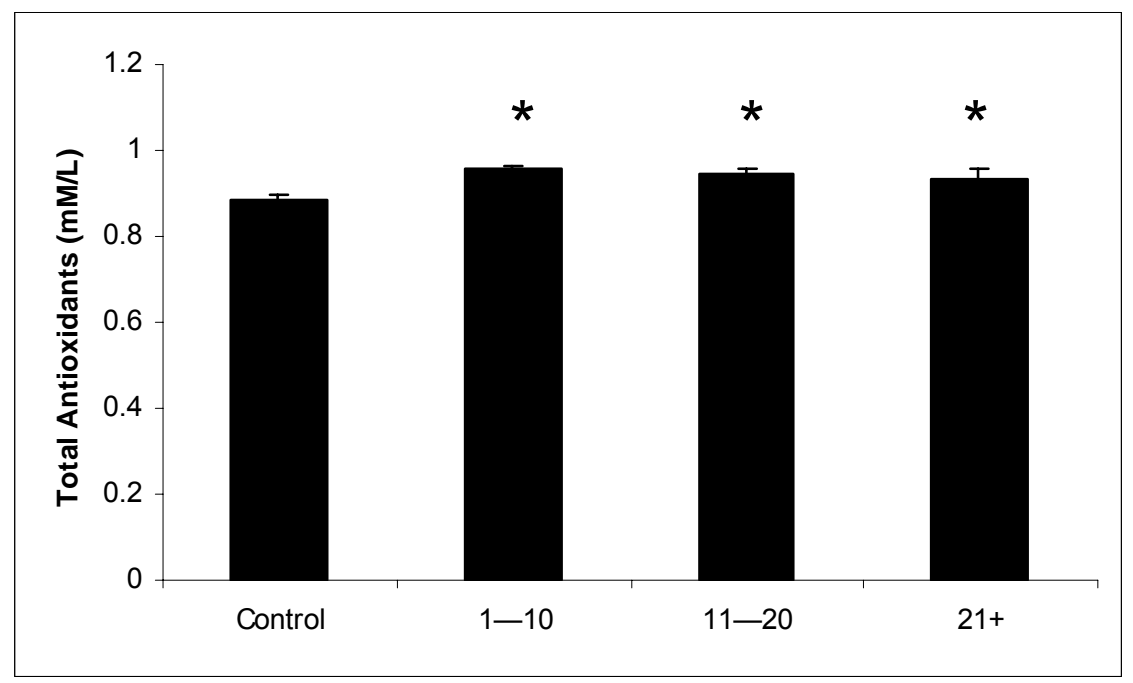

Figure 30. Total antioxidant status in the serum of controls and welders. Total antioxidant status in the serum of controls and welders showed significant upregulation with 1-10 years exposure $(p=0.001), 11-20$ years exposure $(p=0.01), 21$ or more years of exposure $(p=0.02)$, compared to controls. 


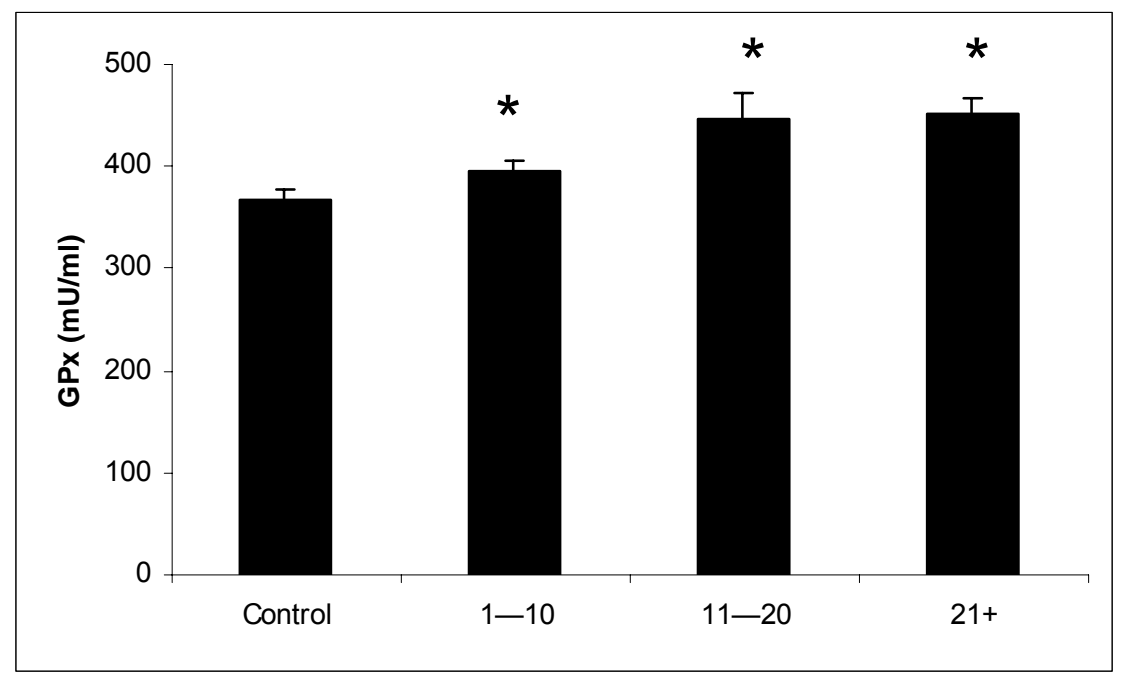

Figure 31. Serum GPx activity in the serum of controls and welders. Serum GPX activity showed an exposure to welding-dependent upregualtion which was more significant at $11-20$ years $(p=0.001)$, and 21 or more years of exposure $(p=0.001)$. 


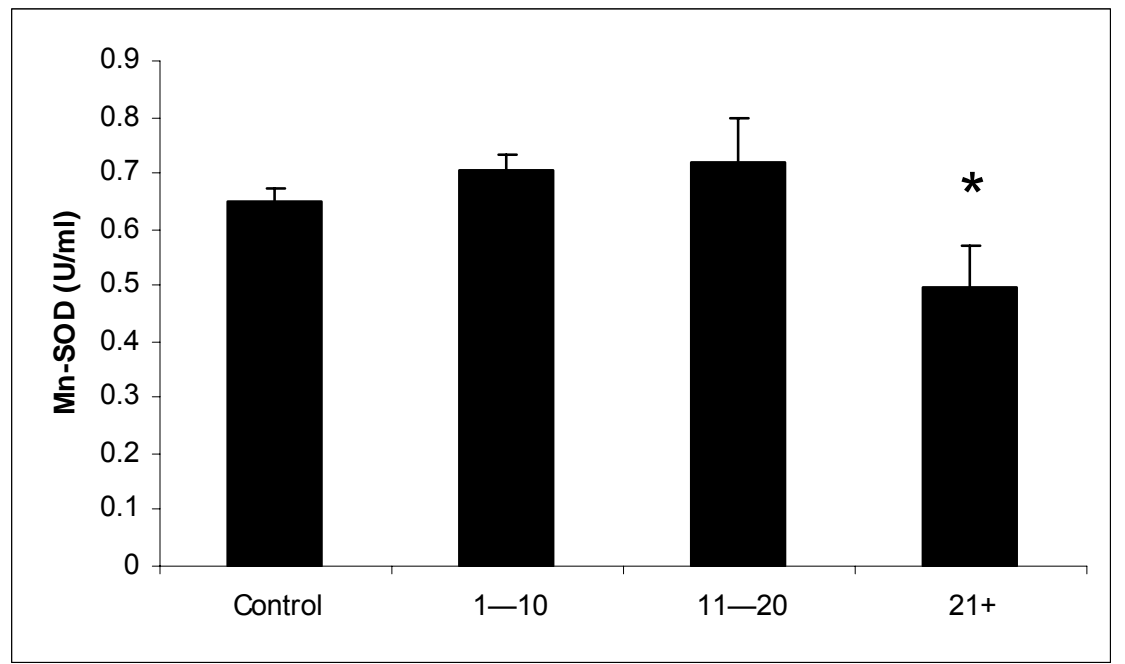

Figure 32. Mn-SOD in the serum of controls and welders. Mn-SOD in the serum of welders showed a moderate increase with exposure to 1-10 years and 11-20 years. With continued exposure to 21 or more years of exposure Mn-SOD showed a significant $(p=0.04)$ depletion. 


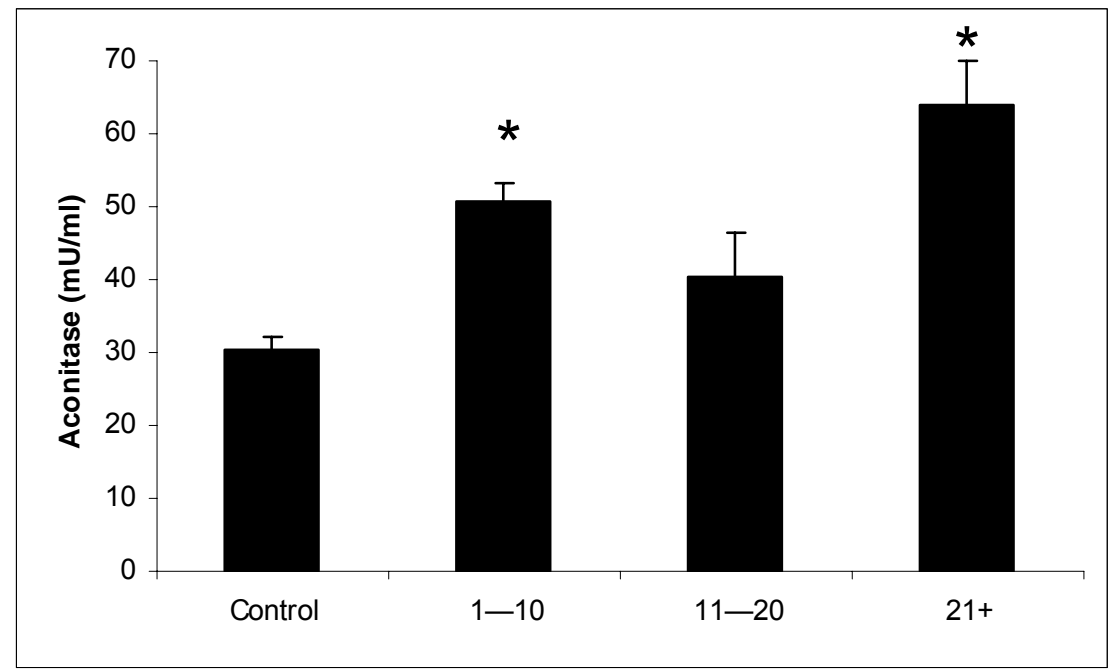

Figure 33. Aconitase activity in the serum of controls and welders. Aconitase activity in the serum of welders showed a significant $(p=0.001)$ increase at $1-10$ of exposure and then a decline at 11-20 of exposure. This transient decline was followed by a significant $(p=0.005)$ upregulation in welders with 21 or more years of exposure. 


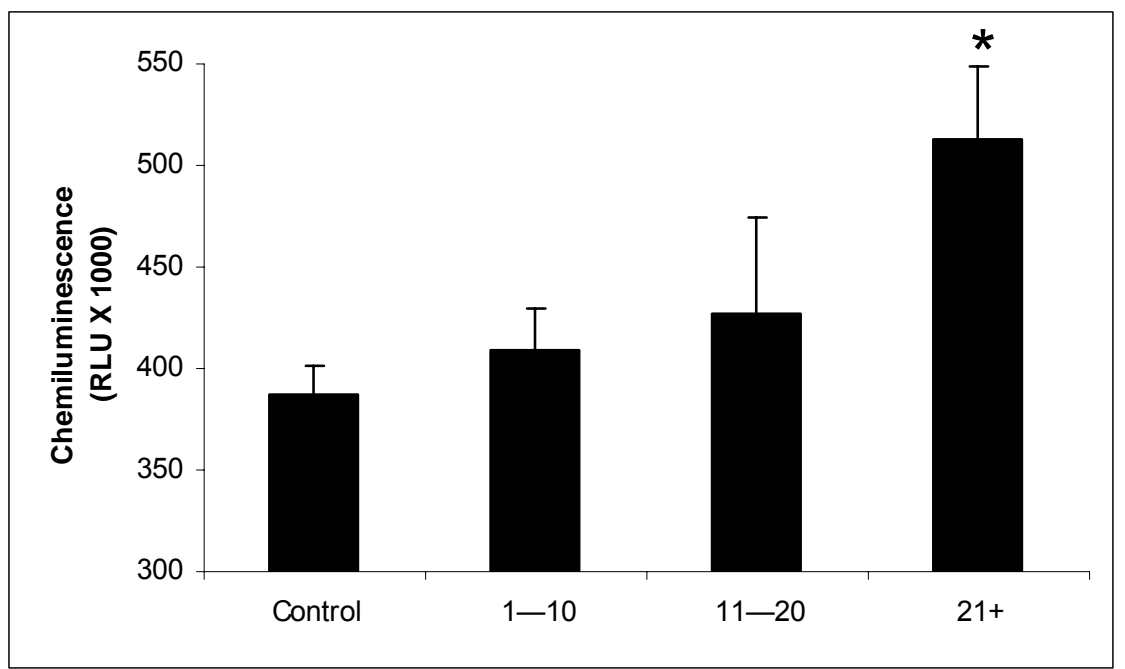

Figure 34. ROS generation potential in the serum by CL of controls and welders. Potential for the generation of reactive oxygen species monitored by chemiluminescence showed steady but nonsignificant increase at 1-10 years and 11-20 years of exposure. Continued exposure to welding for 21 or more years produced a significant $(p=0.001)$ increase in ROS generation compared to controls. 


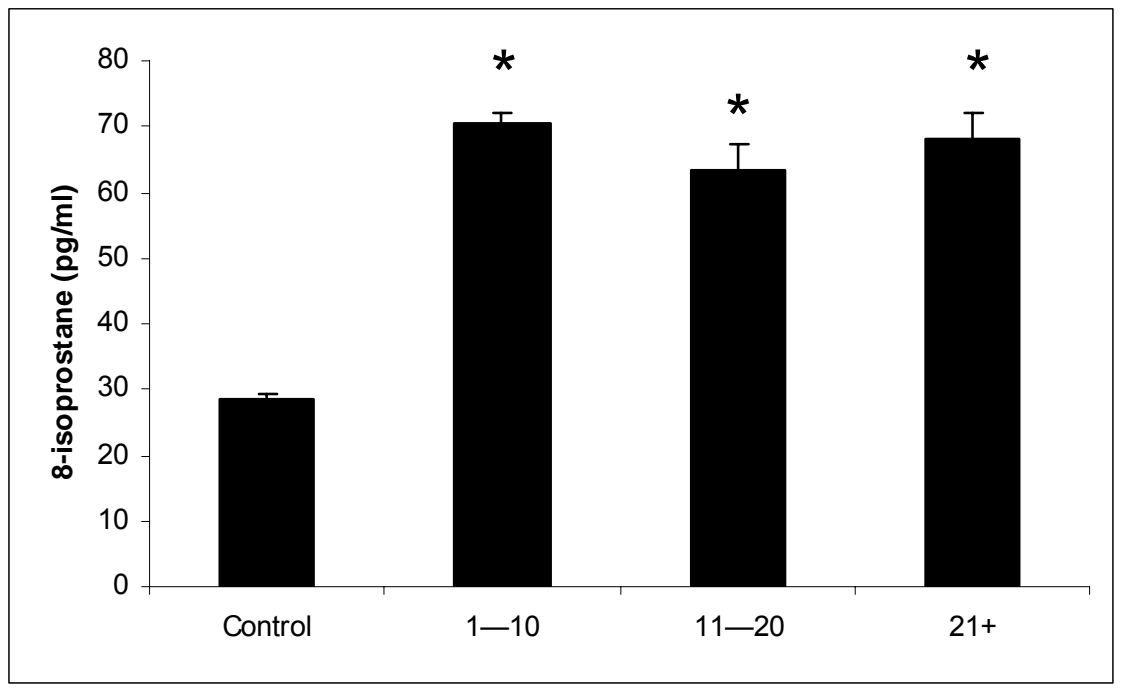

Figure 35. Lipid peroxidation in the serum of controls and welders. Isoprostane levels at all exposure periods showed a consistent significant $(p=0.001)$ increase compared to controls. 


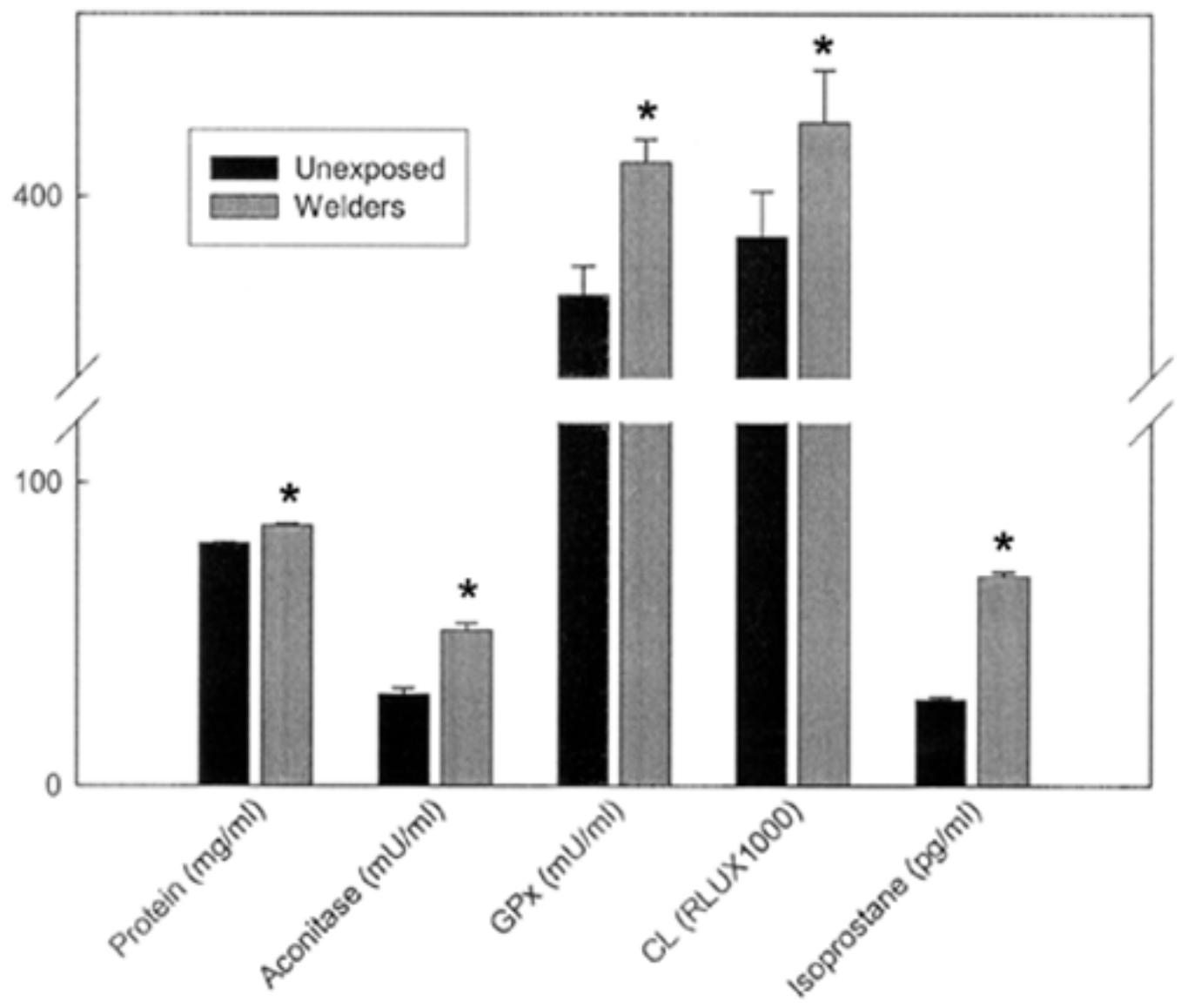

Figure 36. Comparison of all controls with welders showing major differences in the increase of certain correlates of oxidative stress in the serum. 


\section{DISCUSSION}

This investigation was undertaken to explore the potential correlates of oxidative stress in the serum of asymptomatic welders so that in prospective investigations we could ascertain whether any of the biomarkers closely reflect the development of disease. Our aim was also to identify whether any of the correlates of ROS-induced changes measured in the serum show parallel upregulation or downregulation with continued exposure to welding fumes. A third aim of the study was to investigate whether any of the biomarkers of oxidative stress are targets of independent or combined toxic effects of welding exposure and cigarette smoking. The results presented in this study provide several clues supporting ROS-mediated changes in antioxidant status, free radical generation potential and resulting lipid peroxidation by products in serum of welders as excellent biomarkers of welding fume exposure. Moderate changes in age matched controls with and without cigarette smoking exposure also suggests possible direct relationship with some of the oxidant-induced changes and toxic effect of cigarette smoking.

Exposure to welding fumes in occupational settings causes a variety of biological effects in welders. Chronic respiratory effects associated with welding fume exposure are well documented which include bronchitis, occupational asthma, airway irritation, lung function changes, and increase in lung cancer incidence $(2,8-10)$. Neurological, reproductive, and dermatological effects of welding fume exposure are also widely studied. The fumes generated during welding processes contain many toxic metals such as manganese, iron, chromium, and nickel. The vaporized metals become oxidized in air and are then absorbed through skin or inhaled by respiration. Different metal components of welding fumes have diverse intrinsic toxic biologic properties. Several metals commonly present in welding fumes including iron, chromium, nickel and 
manganese are believed to be generating ROS via Fenton or Fenton-like reactions resulting in oxidative stress $(2,11-14)$. Consequently, the increased generation of ROS has been shown to disrupt the biochemical homeostasis inducing lipid peroxidation, DNA damage, depletion of sulfahydryls, and altered calcium homeostasis (15). Therefore, quantitative measurements of markers of oxidative stress in the serum of welders may be valuable in monitoring the changes caused by welding fume exposure.

In the present study, the potential for ROS generation with a parallel significant increase in lipid peroxidation by-product, 8-isoprostane was observed in welders with increasing number of years to welding fume exposure compared to age matched controls. Furthermore, in welders with 20 or more years of exposure the free radical generating potential was significantly higher compared to exposure groups with 1-10 and 11-20 years. This suggests a direct relationship between the welding exposure associated ROS generation and resulting oxidative injury by-products in the serum. These results are consistent with previous findings in human and animal experimental studies showing significant increase in lipid peroxidation caused by welding fume exposure $(16,17)$. In addition, in a recent cross sectional study of toll collectors with potential exposure to diesel exhaust it was reported that serum malondialdehyde and nitrite+nitrate levels increased in comparison to age and smoking matched controls (18). Other biomarkers of oxidative stress associated with welding exposure such as total proteins, albumin, total antioxidant status and Mn-SOD showed significant downregulation as a result of welding exposure which were more pronounced in welders with 20 or more years of welding exposure. Total protein and albumin were measured as markers of pulmonary injury and potential targets of oxidative injury induced by the exposure to toxic welding fumes. Increase in the levels of albumin is often associated with endothelial injury to alveolar-capillary barrier. Increase in the levels of protein is often associated with many disease conditions. The increased serum concentrations of 
total protein and albumin in welders with 1-10 and 11-20 years of exposure may have resulted from lung injury caused by the welding fume exposure. However, both total protein and albumin concentrations in the serum of welders with 20 or more years of exposure were significantly reduced due to persistent oxidative stress. The depletion of these primary antioxidant defenses and inability of welders to upregulate in par with oxidant generation may facilitate disease development. The magnitude of these declines specifically in total proteins and albumin with continued exposure to welding provide further indication of the total disruption of homeostasis. Antioxidant enzymes are much lower in serum compared to intracellular levels and blood proteins and albumin are therefore subjected to more severe oxidative stress than intracellular fluids (19). The serum proteins and albumin are considered "sacrificial" targets of oxidative injury and they are often oxidatively denatured $(19,20)$.

The antioxidant enzyme GPx and a mitochondrial enzyme vulnerable to oxidantmediated loss increased substantially with continued exposure welders compared to controls except for aconitase showing a depletion in welders with 11-20 years of exposure. This was contrary to our expectation that these antioxidants will be depleted with continued exposure to welding fumes. However, this is not surprising in the light of a recent report on the level of antioxidant enzymes, plasma vitamins $C$ and $E$ in cement plant workers demonstrating a $51 \%$ decrease in GPx and $44 \%$ decrease in SOD compared to controls (21). Similar results in serum SOD, GPx and catalase were also reported in oxidative stress-induced by sulfur dioxide with increased lipid peroxidation by-product (22). GPx is involved in the removal of toxic $\mathrm{H}_{2} \mathrm{O}_{2}$ by converting it to water, thereby limiting lipid peroxidation. Aconitase is an important member of the citric acid cycle and is often a target of mitochondrial oxidant injury. As a result of oxidative damage aconitase activity is often reported to be decreased in certain disease conditions associated with ROS. 
It is believed that tightly controlled levels of antioxidant enzymes may protect cells against oxidants in normal or adverse health conditions. Total antioxidant status and glutathione peroxidase were significantly increased in the welders. This indicates that the increased oxidative stress by welding fume triggers the upregulation of defenses to protect cells. This is supported by the continued upregulation of certain antioxidants in welders with 21 or more years of exposure. Although, we expected an increase in Mn-SOD, because manganese is a constituent of welding and Mn-SOD is believed to be activated by cytokines, inhalation of particles, and inflammation, this antioxidant activity showed only a moderate increase in welders with 11-20 years of exposure and declined in welders with 21 or more years of exposure. However, in combined oxidative stressinduced by smoking and welding fume exposure, there was a moderate nonsignificant increase in Mn-SOD in welders compared to controls. Li et al. (16) reported in a study of 37 automobile welders a $24 \%$ decline in erythrocyte SOD activity. Therefore these selective biochemical responses in response to the extent and severity of toxic burden may be characterized by differential oxidative damage in primary and secondary antioxidants.

Inducible $\mathrm{Hsp70}$ is present at basal levels in human serum and is often upregulated in response to stress, toxic agents, ROS, heat and cold (23). Therefore, Hsp70 was evaluated as a potential biomarker of exposure to welding fumes. In welders and control population Hsp levels in the serum was not influenced either by welding fume exposure or cigarette smoking.

In recent years chronic exposure to welding fumes was implicated as a risk factor in the development of certain neurological disorders such as Parkinson's disease, or to a generalized neurofunctional condition called "manganism" $(24,25)$. Manganese, a component of most welding fumes, has been reported to be an environmental toxic metal implicated in CNS injury and manganism. Manganese is attributed for its ability to 
produce free radicals at cytotoxic levels causing oxidative stress and neurodegeneration (26). Manganese is transported in the blood stream and is able to cross the blood-brain barrier through specific carriers (27). In this study population of welders, the mean manganese concentration in the blood was $1.48 \pm 0.03 \mu \mathrm{g} / \mathrm{dl}$ and mean ambient exposure concentration in the air was $1.1 \pm 2.0 \mathrm{mg} / \mathrm{m}^{3}$. Accumulation of manganese alters dopaminergic functions in the basal ganglia in brain causing Parkinson's like syndrome (28). However, manganese has been shown to inhibit iron-induced lipid peroxidation (29) and is a constituent of an important antioxidant enzyme, Mn-SOD. In a study of 121 manganese exposed welders and non-exposed controls randomly selected from 750 workers from 10 different facilities where exposure to manganese is documented including the same ship building facility, $73.5 \%$ of workers showed an increase in signal intensities on the T1-weighted image indicating recent exposure to manganese (30). Whether these asymptomatic welders showing significant changes in markers of oxidative stress in serum which may correspond to welders with the neurofunctional condition of "manganism," remains to be explored in prospective studies. In conclusion, our studies demonstrate that welding fume exposure enhanced generation of ROS and induced oxidative stress causing some damage in target cells resulting in disruption of homeostasis which may promote the development of a disease state with continued occupational exposure to welding fumes. Prospective studies using these non-invasive biomarkers of oxidative stress combined with close clinical monitoring of disease are warranted. 


\section{REFERENCES}

1. Sundin DS. National occupational exposure survey data base, 1981-1983. In NIOSH Criteria for Recommended Standard for Welding, Brazing, and Thermal Cutting (US Department of Health and Human Services, Public Health Service, Centers for Disease Control and National Institute for Occupational Safety and Health, Eds.), Publication No. 88-10.

2. Antonini JM: Health effects of welding. Crit Rev Toxicol 2003;33:61-103.

3. Stern RM. Process-dependent risk of delayed health effects for welders. Environ Health Perspect 1981;41:235-253.

4. Beach JR, Dennis JH, Avery AJ, Bromly CL, Ward RJ, Walters EH, Stenton SC, Hendrick DJ. An epidemiologic investigation of asthma in welders. Am J Respir Crit Care Med 1996;154(5):1394-1400.

5. Wang ZP, Larsson K, Malmberg P, Sjogren B, Hallberg BO, Wrangskog K. Asthma, lung function, and bronchial responsiveness in welders. Am $\mathrm{J}$ Ind Med $1994 ; 26(6): 741-754$.

6. Sobaszek A, Boulenguez C, Frimat P, Robin H, Haguenoer JM, Edme JL. Acute respiratory effects of exposure to stainless steel and mild steel welding fumes. $J$ Occup Environ Med 2000;42(9):923-931.

7. IARC. 1990. Chromium, nickel, and welding. In: IARC monographs on the evaluation of carcinogenic risks to humans. Geneva: IARC. P447-525.

8. Beckett WS, Russi MB, Haber AD, Rivkin RM, Sullivan JR, Tameroglu Z, Mohsenin $\mathrm{V}$, Leaderer BP. Effect of nitrous acid on lung function in asthmatics: a chamber study. Environ Health Perspect 1995;103(4):372-375.

9. Beckett WS. Occupational respiratory disease. N Engl J Med 2000;342(6):406-413. 
10. Korczynski RE. Occupational health concerns in the welding industry. Appl Occup Env Hyg 2000;15:936-945.

11. Toyokuni S. Iron and carcinogenesis: from Fenton reaction to target genes. Redox Rep 2002;7(4):189-197.

12. Shi X, Dalal NS, Kasprzak KS. Generation of free radicals from hydrogen peroxide and lipid hydroperoxides in the presence of $\mathrm{Cr}(\mathrm{III})$. Arch Biochem Biophys $1993 ; 302: 294-299$.

13. Torreilles J, Guerin MC. Nickel (II) as a temporary catalyst for hydroxyl radical generation. FEBS Lett 1990;272(1-2):58-60.

14. Ali SF, Duhart HM, Newport GD, Lipe GW, Slikker W Jr. Manganese-induced reactive oxygen species: comparison between $\mathrm{Mn}+2$ and $\mathrm{Mn}+3$. Neurodegeneration 1995;3:329-334.

15. Stohs SJ, Bagchi D. Oxidative mechanisms in the toxicity of metal ions. Free Radic Biol Med 1995;18(2):321-336.

16. Li GJ, Zhang LL, Lu L, Wu P, Zheng W. Occupational exposure to welding fume among welders: alterations of manganese, iron, zinc, copper, and lead in body fluids and the oxidative stress status. J Occup Environ Med 2004;46(3):241-248.

17. Taylor MD, Roberts JR, Leonard SS, Shi X, Antonini JM. Effects of welding fumes of differing composition and solubility on free radical production and acute lung injury and inflammation in rats. Toxicol Sci 2003;75(1):181-191.

18. Arback P, Yavuz O, Bukan N, Balbay O, Ulger F, Annakkaya AN. Serum oxidant and antioxidant levels in diesel exposed toll collectrs. J Occup Health 2004;46:281288.

19. Halliwell B. Reactive oxygen species in living systems. Source, biochemistry and role. Am J Med 1991;9:114-221. 
20. Quinlan GJ, Mumby S, Martin GS, Bernard GR, Gutteridge JM, Evans TW. Albumin influences total plasma antioxidant capacity favorably in patients with acute lung injury. Crit Care Med 2004;32(3):755-759.

21. Aydinn S, Aral I, Kilic N, Bakan I, Aydin S, Erman F. The level of antioxidant enzymes, plasma vitamins $\mathrm{C}$ and $\mathrm{E}$ in cement plant workers. Clin Chim Acta 2004;341:193-198.

22. Gokirmak M, Yildirim Z, Canan HH, Koksal N, Mehmet N. The role of oxidative stress in bronchoconstriction due to occupational sulfur dioxide exposure. Clin Chem Acta 2003;331:119-126.

23. Mangurten AB, Brader KR, Loos BM, Lee E, Quiroga AI, Bathori J, Lurain JR, Laszlo A, Phillips B. Hsp70 and Hsc70 are preferentially expressed in differentiated epithelial cells in normal human endometrium and ectocervix. Cell Stress Chaperones 1997;2(3):168-174.

24. Lucchini R, Apostoli P, Perrone C, Placidi D, Albini E, Migliorati P, Mergler D, Sassine MP, Palmi S, Alessio L. Long term exposure to low levels of manganese oxides and neurofunctional changes in ferroalloy workers. NeuroToxicol 1999;20:287-298.

25. Hudson NJ, Evans AT, Yeung CK, Hewitt PJ. Effect of process parameters upon the dopamine and lipid peroxidation activity of selected MIG welding fumes as a marker of potential neurotoxicity. Ann Occup Hyg 2001;45(3):187-192.

26. Hamai D, Bondy SC. Oxidative basis of manganese neurotoxicity. Ann N Y Acad Sci 2004;1012:129-141.

27. Aschner M, Vrana KE, Zheng W. Manganese uptake and distribution in the central nervous system (CNS). Neurotoxicology 1999;20:173-180.

28. Daniels AJ, Abarca J. Effect of intranigral Mn2+ on striatal and nigral synthesis and levels of dopamine and cofactor. Neurotoxicol Teratol 1991;13(5):483-487. 
29. Tampo Y, Yonaha M. Antioxidant mechanism of $\mathrm{Mn}(\mathrm{II})$ in phospholipid peroxidation. Free Radic Biol Med 1992;13(2):115-120.

30. Kim Y, Kim KS, Yang JS, Shin YC, Park IJ, Kim E, Jin Y, Kwon KR, Chang KH, Kim JW, Park SH, Lim HS, Cheon HK, Park J, Moon Y. Increase in signal intensities on T1-weighted magnetic resonance images in asymptomatic manganese-exposed workers. Neurotoxicology 1999;20(6):901-908. 


\section{Sung Gu Han, Ph.D. \\ 135 Glen Abbey Lane \\ Morgantown WV 26508}

(T) $304-285-6180$

amq5@cdc.gov

\section{Curriculum Vitae}

\section{Education}

West Virginia University (Morgantown, WV)

2000-2005

Doctor of Philosophy

Program in Genetics and Developmental Biology

Dissertation: Heat shock protein 70 as an indicator of toxic heavy metal exposure and oxidative stress and correlative studies in the serum of asymptomatic shipyard welders

Konkuk University (Seoul, South Korea)

1996-1998

Master of Science

College of Animal Husbandry

Department of Animal Products Science

Thesis: Antitumor activity of extracts from Oldenlandia Diffusa.

Konkuk University (Seoul, South Korea)

1990-1995

Bachelor of Science

Department of Animal Products Science

\section{Research Experience}

Regular Research Fellow

2002-2005

National Institute for Occupational Safety and Health,

Pathology and Physiology Research Branch,

Research focuses on heat shock protein 70 as a

biomarker of lung damage caused by metal exposure.

Researches on changes in the serum of shipyard welders specifically investigating oxidative stress and free radical generation caused by welding fume exposure.

Research Assistant

2001-2002

West Virginia University, Health Sciences Center, Department of Pathology 
Research focused on the function of metallothionein genes in the human prostate cell line 267B-1.

Effects of cadmium on the toxicity and induction

of metallothionein in the human prostate cell line 267B-1.

\section{Teaching Experience}

Teaching Assistant/Laboratory Instructor

1996-1998

Konkuk University,

College of Animal Husbandry,

Taught Undergraduate Laboratory Classes:

Biochemistry

General Microbiology

Food Microbiology

\section{Laboratory Skills and Research Experience}

My current research for the completion of graduate studies I used several molecular techniques to investigate the mechanisms of metal-induced carcinogenesis. For these studies I used several molecular and conventional techniques such as cell cycle regulation, electrophoresis, molecular cloning/subcloning, DNA sequence analysis, Western blot analysis, restriction mapping, PCR and RT-PCR techniques, cell culture, cell transformation, transfection, quantitation of gene transcripts, immunoassay, and quantitation studies on mRNA and proteins by ELISA techniques.

Site directed mutagenesis, bacteria culturing for competent cells, and RNA interference studies were involved in my studies.

\section{Expertise in the Use of Special Instrumentations}

Electron Spin Resonance Spectrometry (ESR). I used ESR studies to the generation of reactive oxygen species in vitro cellular studies. In these studies DMPO, a spin trap, was used to monitor the generation of hydroxyl radical in cells grown in culture, lavaged alveolar macrophages and extracellular biological fluids such lung lavage fluid and serum.

Phopholmager, Micro-Plate Chemiluminescence Reader with Injector, Flow Cytometer, Coulter Counter with Cell Sizer, Cobas Mira AutoAnalyzer, Fluorescence Plate Reader, Spectrophotometers, Confocal Microscopes and other general laboratory equipments

\section{Expertise in General Laboratory Procedures and Assays}

Cell culturing, estimation of population dynamics by counting, colony formation, cytotoxicity assays. Cell freezing, revival and maintenance. 
Measurement of several toxicity studies such as lactate dehydrogenase, n-acetyl glucosaminidase, albumin, protein, cytokines, nitric oxide, reactive oxygen species, glutathione, lipid peroxidation, antioxidants, aconitase, superoxide dismutase, manganese superoxide dismutase, hydrogen peroxide and heat shock proteins.

\section{Chemiluminescence Studies}

When ESR techniques are not feasible chemiluminescence was used to monitor the potential to generate reactive species generated using a CL Plate Reader with microinjection facility.

\section{In Vivo Animal Experiments}

Pharyngeal aspiration of silica in mice for monitoring acute toxicity by lavage, cell differentiation, and toxicity evaluations.

Intraperitoneal injection of POBN and extraction of lung for testing free radicals trapped in POBN. ROS trapped in POBN is extracted by lipid solvents and measured by ESR.

Sacrifice, collecting lung lavage fluid and organs for assays.

\section{Computer Skills}

Sigma Stat, Sigma Plot; Microsoft Excel, Word, Powerpoint; Adobe Photoshop etc

\section{Publications}

\section{Manuscripts}

Sung Gu Han, Vince Castranova, and Val Vallyathan. Heat shock protein 70 as an indicator of early lung injury caused by exposure to arsenic. Molecular and Cellular Biochemistry. (Submitted 2005).

Sung Gu Han, Yangho Kim, Donna Pack, Michael L. Kashon, Vince Castranova, and Val Vallyathan. Correlates of oxidative stress and free radical activity in the asymptomatic shipyard welder's serum. American Review of Respiratory and Critical Care Medicine. (In Press 2005).

Sung Gu Han and Val Vallyathan. Comparative cytotoxicity of metals and their correlation with free radical generation, and heat shock protein expression in a human bronchial epithelial cell line, BEAS-2B. (In preparation).

Sung Gu Han and Val Vallyathan. Quantitative differences in Hsp70A, Hsp70B and Hsp70C mRNA expression for the differential diagnosis of arsenic exposure. (In preparation). 


\section{Abstracts}

Sung Gu Han, Vince Castranova, and Val Vallyathan. Heat shock protein 70 as an indicator of early lung injury caused by exposure to arsenic.

Society of Toxicology Annual Meeting. April 2004.

Sung Gu Han, and Val Vallyathan. Comparison of Metals in Cytotoxicity, Free Radical Generation, and Heat Shock Protein Expression in a Human Bronchial Epithelial Cell Line, BEAS-2B. Society of Toxicology Annual Meeting. March 2005

Sung Gu Han, Yangho Kim, Donna Pack, Vince Castranova, and Val Vallyathan. Correlates of Oxidative Stress and Free Radical Activity in the Serum of Asymptomatic Shipyard Welders. American Thoracic Society Meeting. May 2005

\section{PERSONAL}

Date of Birth: August 20, 1970

Gender: Male

Marital Status: Married

Citizenship: South Korea

\section{REFERENCES}

Dr. Val Vallyathan (Advisor)

Team Leader, National Institute for Occupational Safety and Health 1095 Willowdale Rd, Morgantown, WV 26505

Email: vav1@cdc.gov

Office: $304-285-5770$

Fax: 304-285-5938

Dr. Vincent Castranova

Branch Chief, National Institute for Occupational Safety and Health 1095 Willowdale Rd, Morgantown, WV 26505

Email: vic1@cdc.gov

Office: $304-285-6032$

Fax: 304-285-5938

Dr. Sharon Wenger

Professor, Genetics \& Developmental Biology, Department of Pathology

West Virginia University, Morgantown, WV 26506

Email: swenger@hsc.wvu.edu

Office: 304-293-0446

Fax: 304-293-3976 